\title{
The effect of reduced management intensity on soil nutrient dynamics in a large-scale oil palm plantation: soil nitrogen cycle, asymbiotic nitrogen fixation and nutrient leaching losses
}

\author{
Dissertation \\ to attain the doctoral degree Dr. rer. nat. \\ of the Faculty of Forest Sciences and Forest Ecology \\ of Georg-August-Universität Göttingen \\ Submitted by \\ Greta Formaglio \\ born on the \\ 15.09.1991 in Monza, Italy
}

Göttingen, July 2020 

$1^{\text {st }}$ Referee: Marife D. Corre $2^{\text {nd }}$ Referee: Klaus Dittert Date of oral examination: 26.06.2020 



\section{Summary}

Oil palm plantations are rapidly expanding in the tropics, triggered by increasing demand of vegetable oil and by their high productivity. Large part of palm oil is produced in large-scale plantations employing intensive agricultural management practices, which are associated with negative environmental impacts and may reduce soil fertility. Therefore there is a need to reduce this environmental footprint and to establish management practices that support long-term soil fertility without sacrificing the yield.

We established a management experiment in a large-scale oil palm plantation to determine if the reduction of management intensity may promote soil fertilty. This experiment had factorial treatment combinations of two fertilization rates $(260 \mathrm{~N}, 50 \mathrm{P}$, $220 \mathrm{~K} \mathrm{~kg} \mathrm{ha}^{-1} \mathrm{yr}^{-1}$ as conventional practice, and $136 \mathrm{~N}, 17 \mathrm{P}, 187 \mathrm{~K} \mathrm{~kg} \mathrm{ha}^{-1} \mathrm{yr}^{-1}$, equal to harvest export, as reduced management) and two weeding methods (conventional herbicide, and mechanical weeding as reduced management). The three management zones of large-scale oil palm plantations were considered: the palm circle, where the fertilizer is applied and regularly weeded; the unfertilized and weeded inter-row; the frond-stacked area, where the cut fronds are piled up on the soil. In this experiment, we conducted three studies to investigate three soil processes: the soil $\mathrm{N}$ cycle, soil and litter biological asymbiotic $\mathrm{N}_{2}$ fixation and nutrient leaching losses.

In the first study, we measured the soil-N-cycling rates in the top-5-cm depth, using the ${ }^{15} \mathrm{~N}$ pool dilution technique, as well as soil nutrient contents. While there were no differences among experimental treatments, there were clear differences among management zones. The highest soil-N-cycling rates were in the frond-stacked area. The main driver of the soil $\mathrm{N}$ cycle was microbial biomass $\mathrm{N}$, which was controlled by soil organic matter. The decomposition of senesced fronds provided ample substrate to sustain high microbial biomass and high rates of soil-N cycling in the frond-stacked 
area, also promoting soil fertility (e.g. low bulk density, high organic matter, high base saturation).

In the second study, we measured biological asymbiotic $\mathrm{N}_{2}$ fixation in the top-5-cm of soil and in the frond litter. We used the acetylene reduction assay with monthly measurements for one year. There was no effect of the experimental treatment on asymbiotic $\mathrm{N}_{2}$ fixation but there were differences among management zones. The palm circle had the highest $\mathrm{N}_{2}$ fixation rates due to high $\mathrm{pH}$ and the frond-stacked area had the lowest $\mathrm{N}_{2}$ fixation rates because of high soil $\mathrm{N}$ contents. The litter had high rates of $\mathrm{N}_{2}$ fixation on mass-basis, but, given the small coverage of the litter in the plantation, the rates on area-basis were low.

In the third study, we measured nutrient leaching losses at $1.5 \mathrm{~m}$ depth for one year and nutrient contents in the top-50-cm soil. We collected monthly deep-soil water samples with suction cup lysimeters and we estimated the water drainage flux by modeling the water balance. The reduced fertilization treatment and the mechanical weeding treatment had lower leaching fluxes than the conventional treatments because of lower nutrient inputs and higher retention by enhanced cover vegetation. The palm circle had generally low leaching fluxes because of high plant uptake, whereas the inter-row had the highest leaching losses of $\mathrm{N}$ and $\mathrm{Al}$, because of low plant retention, lateral transport of $\mathrm{N}$, and acidic $\mathrm{pH}$.

Altogether these results highlighted the differences among management zones. In the frond-stacked area, the high soil-N-cycling rates, microbial biomass, nutrient contents and water drainage flux show the importance of mulching with senesced fronds to restore some soil functions. Lower fertilization rates and mechanical weeding were effective practices to reduce nutrient leaching losses, reducing the environmental footprint of the plantation. Also, the yield was comparable among experimental treatments, suggesting that reduced management intensity can maintain high productivity. 


\section{Zusammenfassung}

Der Flächenverbrauch durch Palmölplantagen ist in den Tropen stark angestiegen was vor allem durch die hohe Produktivität und eine stark gestiegene Nachfrage nach günstigem Palmöl ausgelöst wurde. Ein großer Teil des Palmöls wird in weitläufigen Plantagen mit intensiver Landwirtschaft angebaut. Oft sind negative Folgen für die Umwelt und Bodenfruchtbarkeit mit dieser Art der Bewirtschaftung verbunden. Das verstärkt die Notwendigkeit bodenschonende Anbaumethoden zu etablieren um bei gleichem Ertrag die Bodenfruchtbarkeit langfristig zu erhalten und den ökologischen Fußabdruck des Ölpalmenanbaus zu reduzieren.

Die Auswirkungen einer reduzierten Bewirtschaftung auf die Bodenfruchtbarkeit, wurden in dieser Studie in einem groß angelegten Feldversuch in einer kommerziell bewirtschafteten Palmölplantage untersucht. In diesem Experiment wurden zwei verschiedene faktorielle Behandlungskombinationen bestehend aus zwei Düngemittelmischungen $\left(260 \mathrm{~N}, 50 \mathrm{P}, 220 \mathrm{~K} \mathrm{~kg} \mathrm{ha}^{-1} \mathrm{yr}^{-1}\right.$ für konventionelle Bewirtschaftung und 136 $\mathrm{N}, 17 \mathrm{P}, 187 \mathrm{~K} \mathrm{~kg} \mathrm{ha}^{-1} \mathrm{yr}^{-1}$, für eine schonendere Bewirtschaftung) und zwei Unkrautbehandlungsmethoden (konventionelle Herbizide und mechanisches Jäten) verwendet. Die drei typischen Managementzonen der großflächigen Palmölbewirtschaftung berücksichtigt: (1) Der Palmkreis der frei von Bodengewächsen gehalten wird und innerhalb dessen das Düngemittel appliziert wird, (2) der ungedüngte Bereich zwischen den Palmenreihen und (3) der Bereich in dem die entfernten Palmwedel zur Kompostierung aufgeschichtet werden.

Drei Detailstudien beschreiben drei Bodenprozesse: den Bodenstickstoffkreislauf, die biologische und asymbiotische Stickstoff-Fixierung in Boden und Bodenstreu und Nährstoffauswaschungsverluste.

In der ersten Studie wurden Bodenstickstoffumsetzungsraten bis in $5 \mathrm{~cm}$ Bodentiefe mithilfe der ${ }^{15} \mathrm{~N}$ Isotopenverdünnungsanalyse und Bodennährstoffgehalte untersucht. 
Während keine Unterschiede bei den verschiedenen Behandlungskombinationen festgestellt werden konnten, waren eindeutige Unterschiede in den verschieden Bewirtschaftungszonen zu erkennen. Die höchsten Umsetzungsraten für Stickstoff wurden in Managementzone (3) gemessen. Hauptsächlich verantwortlich für die Bodenstickstoffumsetzung war die mikrobielle Biomasse die wiederum von der organischen Bodensubstanz beeinflusst wurde. In Managementzone (3) die Bodenstickstoffumsetzung begünstigt durch die gelagerten Palmwedel und deren positiven Einfluss auf die mikrobielle Biomasse zu erhöhter Bodenfruchtbarkeit (unter anderem geringe Bodendichte, hoher Anteil an organischer Bodensubstanz, hohe Basensättigung) führte.

In der zweiten Studie wurde die biologische und asymbiotische Stickstoff-Fixierung bis in $5 \mathrm{~cm}$ Bodentiefe und in Bodenstreu untersucht. Hierzu wurde die AcetylenReduktionsanalyse mit monatlichen Messungen verteilt auf ein Jahr angewandt. Es konnten keinerlei Effekte der verschiedenen Behandlungskombinationen festgestellt werden, allerdings wurden Unterschiede innerhalb der Managementzonen festgestellt. Managementzone (1) wies wegen des hohen $\mathrm{pH}-$ Wertes die höchsten Stickstofffixierungsraten auf. Verglichen dazu konnte in Managementzone (3) aufgrund des hohen Stickstoffgehalts im Boden nur geringe Stickstofffixierungsraten nachgewiesen werden. Für das Bodenstreu konnte eine verstärkte asymbiotische Stickstoff-Fixierung auf Massebasis nachgewiesen werden, allerdings waren die Fixierungsraten wegen des geringen Bodenbedeckungsanteils mit Bodenstreu auf die Fläche gemessen eher gering. Für die dritte Studie wurden Nährstoffauswaschungsverluste in 1.5-m Tiefe über den Zeitraum eines Jahres gemessen. Die Auswaschungsmessungen wurden monatlich mit Tiefbodenwasserproben mit Saugkerzenlysimetern aufgenommen. Außerdem wurde der Wasserabfluss durch Wasserhaushaltsmodellierung berechnet. Die schonendere Düngung hatte folglich geringere Auswaschungsverluste als die konventionelle Düngung. Das mechanische Jäten hatte einen positiven Effekt auf die Vegetationsdecke und die Nährstoffspeicherung was zu geringeren Auswaschungsverlu- 
sten im Vergleich zur Herbizidbehandlung führte. Managementzone (1) hatte wegen der hohen Nährstoffaufnahme der Palmen generell geringere Auswaschungsverluste, während in Managementzone (2) wegen des geringen Pflanzenbewuchses dem horizontalen Stickstofftransport und des sauren Bodenhorizonts die stärksten Nährstoffauswaschungsverluste nachgewiesen werden konnten.

Zusammenfassend verdeutlichen die Ergebnisse der drei Studien die erheblichen Unterschiede zwischen den beschriebenen Managementzonen. Wichtige Bodenfunktionen konnten vor allem in den Bereichen in denen abgeschnittene Palmwedel gelagert wurden wiederhergestellt werden, da in diesen Bereichen hohe Bodenstickstoffumsetzungsraten, der verstärkte Aufbau mikrobieller Biomasse, stärkere Nährstoffgehalte und ein erhöhter Wasserabfluss die Bedeutung von Mulch in den Vordergrund rücken. Die Reduzierung der Bewirtschaftungsintensität konnten geringere Nährstoffauswaschungsverluste nachgewiesen werden. Es konnte kein Einfluss der Behandlungskombinationen auf die Ernteerträge festgestellt werden, was zum Schluss führt, dass trotz reduzierter Düngung und mechanischem Jäten ein hohes Ertragsniveau aufrechterhalten werden kann. 



\section{Contents}

1 General introduction $\quad 1$

1.1 Oil palm plantantions and soil fertility . . . . . . . . . . 2

1.2 Management practices in large-scale oil palm plantations . . . . . . . 3

1.3 Soil nutrient dynamics: biological asymbiotic nitrogen fixation, soil nitrogen cycle and nutrient leaching losses . . . . . . . . . . . . . 6

1.4 Objectives and hypotheses . . . . . . . . . . . . . . . . . 9

2 Senesced fronds amend the soil nitrogen cycle and soil fertility in a large$\begin{array}{ll}\text { scale oil palm plantation } & 19\end{array}$

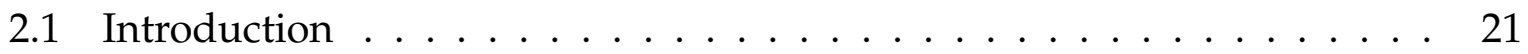

2.2 Materials and Methods . . . . . . . . . . . . . . . . 24

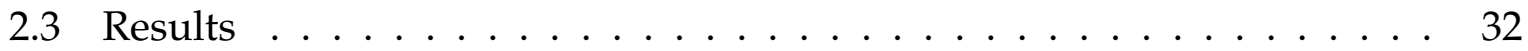

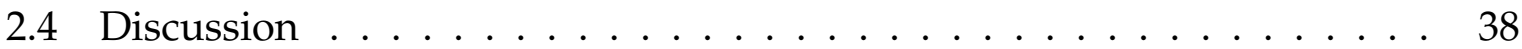

2.5 Conclusion ............................. 43

2.6 Supplementary material $\ldots \ldots \ldots \ldots$. . . . . . . . . . . . 45

3 Biological asymbiotic nitrogen fixation in soil and litter in a large-scale oil palm plantation $\quad 53$

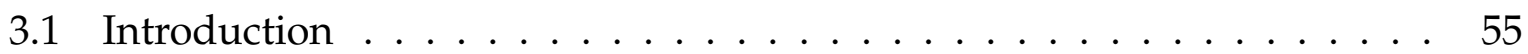

3.2 Materials and Methods . . . . . . . . . . . . . . . . . . 57

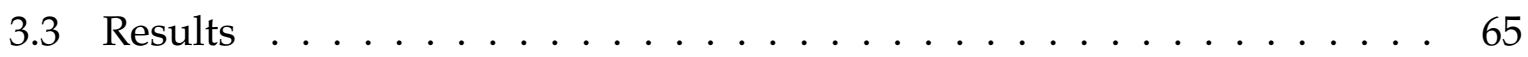

3.4 Discussion . . . . . . . . . . . . . . . . . . . . 69 
3.5 Conclusion $\ldots \ldots \ldots \ldots \ldots \ldots \ldots \ldots \ldots \ldots \ldots \ldots \ldots$

3.6 Supplementary material $\ldots \ldots \ldots \ldots \ldots \ldots \ldots$

4 Herbicide weed control increases nutrient leaching as compared to me$\begin{array}{ll}\text { chanical weeding in a large-scale oil palm plantation } & 81\end{array}$

4.1 Introduction $\ldots \ldots \ldots \ldots \ldots \ldots \ldots \ldots \ldots \ldots \ldots$

4.2 Materials and Methods . . . . . . . . . . . . . . . . 86

4.3 Results . . . . . . . . . . . . . . . . . . 93

4.4 Discussion . . . . . . . . . . . . . . . . . . . . 105

4.5 Supplementary material $\ldots \ldots \ldots \ldots \ldots \ldots \ldots$

5 Synthesis 127

5.1 Effect of reduced management intensity . . . . . . . . . . . . 128

5.2 Spatial differences in the oil palm plantation . . . . . . . . . . 132

5.3 Comparison with smallholder oil palm plantations and forest . . . . 136 
Chapter 1

General introduction 


\subsection{Oil palm plantantions and soil fertility}

Oil palm (Elaeis guineensis) has become one of the dominant agroecosystem in the tropics. The area of oil palm plantations has recorded a remarkable expansion in the last decades, especially in Malaysia and Indonesia (FAO 2018). The latter is the top producer of palm oil worldwide and the main contributors are the islands of Kalimantan and Sumatra (FAO 2018, Directorate General of Estate Crop 2017). The reasons for the success of oil palm are its superior yield and lower management costs compared to other vegetable oils (Carter et al. 2007, Clough et al. 2016). Given the rising demand for cheap oil for cooking and biofuel, the area under oil palm is predicted to expand in the future (Pirker et al. 2016, Corley 2009). There is a rising concern on the environmental impact of the expansion of oil palm, as it is often associated with deforestation and consequent loss of biodiversity (Barnes et al. 2017, Savilaakso et al. 2014), soil degradation (van Straaten et al. 2015, Guillaume et al. 2016, Maranguit et al. 2017) and greenhouse gases emissions (Hassler et al. 2017, Fargione et al. 2008). These negative environmental effects can be mitigated by the development of sustainable agricultural management practices that aim to maintain high levels of production and simultaneously partially restore the ecosystem functions lost during the convertion of forest to oil palm (Foster et al. 2011, Pauli et al. 2014, Dislich et al. 2017). Besides, since oil palm is a perennial crop, with a life-cycle of approximately 25 years (Corley and Tinker 2016), there is a potential to install relatively long-term sustainable management practices.

One important ecosystem function is soil fertility, which is the capacity of the soil to provide sufficient nutrients for plant growth; it is determined by the continuous cycle of nutrients between vegetation and soil (Dislich et al. 2017). Prolonged cultivation has a negative impact on soil fertility (Corre et al. 2006, Davidson et al. 2007, Ngoze et al. 2008) and oil palm plantations have indeed lower soil fertility compared 
to forests (Dislich et al. 2017). The decrease of soil fertility diminishes the capacity of the soil to support high levels of crop production, which have to be maintained by the continuous use of fertilizers (Allen et al. 2016). Also, a severe decline in soil fertility may cause the abandonment of the area with further expansion of oil palm plantations at the expense of other land uses, in particular tropical forest (Vijay et al. 2016). Therefore, management practices in oil palm plantations should focus on the maintenance of long-term soil fertility to reduce the dependency on high fertilizer inputs and prevent further land-use change.

Our work investigates some soil process that regulate soil nutrient dynamics and, ultimately, soil fertility: (1) the soil nitrogen $(\mathrm{N})$ cycle, which includes all the microbial transformations of $\mathrm{N}$ in the soil and determines the soil $\mathrm{N}$-supply capacity and the potential for $\mathrm{N}$ losses from the soil; (2) biological asymbiotic $\mathrm{N}_{2}$ fixation, which is the main natural pathway through which $\mathrm{N}$ enters in the system and (3) nutrient leaching losses from the soil, which deplete the soil from nutrients and eventually reduce soil fertility. We determined these soil processes under different agricultural management practices to understand how management practices affect nutrient dynamics and how they can be adjusted to promote soil fertility. We conducted our experiment in a large-scale oil palm plantation in Sumatra in the province of Jambi, an area that has been a hot-spot for land-use change in the past decade (Drescher et al. 2016).

\subsection{Management practices in large-scale oil palm planta- tions}

Most of the oil palm plantations area in Indonesia is occupied by large-scale plantations (60\% in 2015, Directorate General of Estate Crop 2017), with areas from 3.000 to 40.000 ha, owned by private or governmental enterprises; the rest of the plantations are owned by smallholders, with a maximum area of 50 ha per farmer (Lee et al. 2014). 
In Jambi province smallholder plantations are on average 4 ha (Clough et al. 2016). Large-scale plantations have higher management intensity compared to smallholder plantations and intensive agriculture is generally associated with high negative environmental impacts (Matson et al. 1997, Tilman et al. 2002). Also, since in large-scale plantations few stakeholders manage large areas, there is a real possibility to address environmental concerns and implement sustainable management practices in these plantations. The commonly-employed management practices in large-scale oil palm plantations involve high rates of fertilization and the use of herbicide for weeding (Pahan 2010, Comte et al. 2012). Fertilization with N, phosphorus (P), and potassium $(\mathrm{K})$ is necessary to maintain high yields in tropical soils that are highly weathered and naturally nutrient-poor (Tiemann et al. 2018, Corley and Tinker 2016). In addition, lime is normally applied to maintain the $\mathrm{pH}$ suitable for $\mathrm{P}$ and base cations availability (Schlesinger and Bernhardt 2013, Pahan 2010) and to contrast the acidifying effect of $\mathrm{N}$-fertilization, given the low acid-buffering capacity of tropical soils (Lungu and Dynoodt 2008, Lu et al. 2014, Nelson et al. 2011). On the other hand, weeding is practiced to facilitate the access to the palms for an efficient harvest and to reduce the competition for nutrients and water between palms and understory vegetation (Corley and Tinker 2016, Woittiez et al. 2017, Oberthuer 2012). However, while competition with weeds can reduce the yield in the first stages of oil palm establishment (Corley and Tinker 2016), in mature plantations there has been no evidence of competition (Ashton-Butt et al. 2018, Woittiez et al. 2017). These commonly-employed management practices are associated with negative environmental impacts. High fertilization rates stimulate nutrient losses, connected with greenhouse gases emissions and possible water contamination (Figueiredo et al. 2010, Hassler et al. 2017, Huddell et al. 2020). The use of herbicide reduce the understory vegetation, important for carbon and nutrient cycling (Wang et al. 2011, Xiong et al. 2008, Bigelow et al. 2004), as well as for biodiversity (Luke et al. 2019, Ashton-Butt et al. 2018, Darras et al. 2019). Re- 
ducing the intensity of these management practices, through lower fertilization rates and mechanical weeding instead of herbicide application, may reduce these negative environmental impacts while maintaining high levels of production.

To test this hypothesis a management experiment was established in a largescale oil palm plantation in Jambi, Indonesia. These full-factorial management experiment compared conventionally-employed intensive management practices with reduced intensity of management. The factors of the experiment were fertilization (i.e. conventional rates vs reduced rates, equal to nutrient export via harvest) and weeding (i.e. herbicide weeding vs mechanical weeding). This management experiment was established in the framework of the interdisciplinary research project of EFForTS (Ecological and Socioeconomic Functions of Tropical Lowland Rainforest Transformation Systems), which is a Collaborative Research Center (CRC 990), funded by the Deutsche Forschungsgemeinschaft, of Georg-August University of Göttingen in collaboration with four Indonesian universities: Agricultural University Bogor (IPB), University of Jambi (UNJA), University of Tadulako (UNTAD) and University of Brawijaya (UB). In this oil palm management experiment, the EFForTS project aims to assess the effect of different management intensities on the environmental processes, on biota and biodiversity, and on economic factors, including the yield. As part of this project, our research investigates the soil nutrient dynamics in this management experiment.

To study soil processes in large-scale oil palm plantations it is important to take into account their defined spatial structure (Anuar et al. 2008, Law et al. 2009, Carron et al. 2015). Normally, planting configuration and standard management practices generate three different zones in the soil, which are normally called management zones (Haron et al. 1998, Ashton-Butt et al. 2018). (1) Palm circle, which is a 2-m-radius area around the palm, where the fertilizer is applied and that is regularly weeded and raked. (2) Inter-row, which is the area between the palm rows that is weeded less intensively than the palm circle and is not fertilized. (3) Frond-stacked area, where 
the fronds, which are pruned to reach the fruit during harvest, are stacked on the soil for mulching, every second inter-row. Accounting for the differences in management zones is fundamental for scaling-up soil processes to plantation level. Also, the management zones provide a gradient of management intensity to assess the effect of management practices on soil processes, from intensive fertilization and weeding in the palm circle, to no fertilization and less intensive weeding in the inter-row, and mulching in the frond-stacked area.

\subsection{Soil nutrient dynamics: biological asymbiotic nitro- gen fixation, soil nitrogen cycle and nutrient leaching}

\section{losses}

Nitrogen is the main limiting nutrient of terrestrial primary production and a fundamental nutrient for oil palm growth (LeBauer and Treseder 2008, Tiemann et al. 2018). Differently from the other macronutrients ( $\mathrm{P}$ and $\mathrm{K}$ ), $\mathrm{N}$ is not rock-derived and the main natural pathway through which it enters in the system is via the biological fixation of atmospheric $\mathrm{N}_{2}$. Biological $\mathrm{N}_{2}$ fixation is carried out by microorganisms that live in symbiosis with plants, especially in leguminous trees, or free-living in soil, litter and on plant surfaces (Reed et al. 2011). In oil palm plantations, the leguminous cover, usually planted in the first years, dies out due to light limitation 7-8 year after planting, when the palms are mature and the canopy closes. So that no leguminous trees are found in mature oil palm plantations (Corley and Tinker 2016, Rembold et al. 2017). Therefore, asymbiotic $\mathrm{N}_{2}$ fixation is likely the only form of $\mathrm{N}_{2}$ fixation in oil palm plantation. This process can be an important source of $\mathrm{N}$ for the palms and should be taken into account for rational fertilizer use, but there is no research on the asymbiotic $\mathrm{N}_{2}$ fixation in oil palm plantations (Pardon et al. 2016). The main controlling factors of asymbiotic $\mathrm{N}_{2}$ fixation in tropical forests are soil moisture content, microbial 
community composition, and labile carbon (C) and nutrient (N, P, molybdenum (Mo)) contents (Crews et al. 2000, Barron et al. 2009, Reed et al. 2010, Vitousek et al. 2013, Bomfim et al. 2019). In general, high moisture and $C$ contents favor $\mathrm{N}_{2}$ fixation, $\mathrm{N}$ has an inhibitory effect, and $\mathrm{P}$ and Mo can be limiting nutrients. However nutrient limitation of $\mathrm{N}_{2}$ fixation is complex, as there is often no single-element limitation but rather a multi-element limitation which involves complex relationships of coupled nutrient cycles (Wurzburger et al. 2012, Perakis et al. 2017). Management practices alter the input of nutrients in the system either directly, i.e. via fertilization, or indirectly via weeding and mulching, which affect the nutrient return to the soil and the retention of nutrients in the soil. Also, these practices can affect soil physical characteristics by altering the organic matter content in the soil, which is connected with moisture-holding capacity and bulk density (Moradi et al. 2014, Comte et al. 2012) and by affecting vegetation cover. In addition, soil nutrient contents can affect soil microbial community and composition (Berkelmann et al. 2018), thus affecting N-fixing bacteria. In this study, we measured asymbiotic $\mathrm{N}_{2}$ fixation in the soil and in the frond pile, which represent the main litter of the oil palm plantation, and evaluate the roles of management practices and soil nutrients on regulating this process.

Once $\mathrm{N}$ enters the soil, it is transformed by a series of microbial processes as part of the soil $\mathrm{N}$ cycle. Mineral $\mathrm{N}$, in the forms of ammonium $\left(\mathrm{NH}_{4}{ }^{+}\right)$or nitrate $\left(\mathrm{NO}_{3}{ }^{-}\right)$, is the readily bioavailable form of $\mathrm{N}$. Therefore, the interplay of the processes of production and consumption of mineral $\mathrm{N}$ determines the $\mathrm{N}$-supply capacity of the soil for plant and microbial use. Mineral $\mathrm{N}$ production processes in the soil are $\mathrm{N}$ mineralization, which converts organic $\mathrm{N}$ into $\mathrm{NH}_{4}{ }^{+}$, and nitrification, which produces $\mathrm{NO}_{3}{ }^{-}$ from either organic $\mathrm{N}$ (heterotrophic nitrification) or $\mathrm{NH}_{4}{ }^{+}$(autotrophic nitrification). On the other hand, microbial immobilization represents the internal soil consumption process for mineral $\mathrm{N}$. This is a mechanism of $\mathrm{N}$ retention in the soil, since the $\mathrm{N}$ immobilized is only released into the soil when the microorganisms die and $\mathrm{N}$ is reminer- 
alized. Dissimilatory nitrate reduction to ammonium (DNRA) can also be considered a retention mechanism since it transforms the easily-leached $\mathrm{NO}_{3}{ }^{-}$into $\mathrm{NH}_{4}{ }^{+}$, which is the preferred form of $\mathrm{N}$ for plant uptake (Silver et al. 2001). Management practices in oil palm plantations alter the $\mathrm{N}$ input to the soil, directly influencing the soil $\mathrm{N}$ cycle. Also, management practices influence the return of organic matter to the soil, which is the substrate for mineralization and for microbial biomass growth. Microbial biomass has been identified as the main driver of the soil $\mathrm{N}$ cycle in smallholder oil palm plantations in Jambi province (Allen et al. 2015). In this study, we measured gross rates of soil-N cycling using the ${ }^{15} \mathrm{~N}$ pool dilution technique (Davidson et al. 1991). The term "gross rates" indicates that all the processes of the soil N cycle are measured separately, and it is used in opposition to "net rates", which represents the sum of competing consumptive and productive processes (Hart et al. 1994). While the measurement of net rates can give useful information on plant-available- $\mathrm{N}$, only the gross rates allow to determine the soil $\mathrm{N}$ cycle and to understand the mechanisms and controlling factors that regulate the availability of $\mathrm{N}$ in the soil.

Finally, nutrients can be lost from the system via leaching. Once a nutrient reaches a depth where no roots are present, it cannot be reached by the vegetation and it should be considered lost from the plantation. Reducing nutrient leaching losses is important for the economic and ecological sustainability of oil palm plantations. Given that an important part of the costs of oil palm plantations is related to fertilizer acquisition, it is in the interest of the plantation owners to reduce the leaching of applied fertilizer. On the other hand, leaching losses can have negative effects on the environment, since the elements leached can reach groundwater and flow to water bodies, thus affecting their water quality (Figueiredo et al. 2010, Teklu et al. 2018). Fertilization has a direct impact on leaching losses because it controls the timing and the extent of the nutrient additions into the soil, and in general high fertilization rates are associated with high nutrient leaching losses in the tropics (Huddell et al. 2020). Also, 
fertilization and weeding can alter the capacity of the soil to retain water and nutrients by altering $\mathrm{pH}$, organic matter content and root distribution, thus affecting leaching losses. In this study, we measured the leaching losses and evaluated the effect of management practices (e.g. fertilization, weeding and mulching) on leaching fluxes in an oil palm plantation.

\subsection{Objectives and hypotheses}

Overall this research had two main objectives:

1. To compare the soil $\mathrm{N}$ cycle, asymbiotic $\mathrm{N}_{2}$ fixation and nutrient leaching losses under conventional intensive management practices, (i.e. high fertilization rates and herbicide weeding), and under the reduced intensity of management (i.e. fertilization rates equal to nutrient export via harvest and mechanical weeding) in the oil palm plantation. The purpose was to evaluate whether reduced management intensity can maintain or improve soil fertility and soil functions without affecting productivity.

2. To compare the soil $\mathrm{N}$ cycle, asymbiotic $\mathrm{N}_{2}$ fixation and nutrient leaching losses among the management zones of the plantation (i.e. palm circle, inter-row, and frond-stacked area). The purpose was to assess the spatial variability of soil functions in a large-scale oil palm plantation and to evaluate the effect of the management practices associated with the management zones (i.e. fertilization, weeding and mulching) on soil fertility and soil functions.

Based on these objectives the three main hypotheses were:

1. Reduced fertilization rates to levels of harvest export can maintain soil fertility because the plantation is over-fertilized. We speculated that:

(a) Lower $\mathrm{N}$ fertilization will reduce gross nitrification because of lower $\mathrm{NH}_{4}{ }^{+}$ inputs. 
(b) Lower $\mathrm{N}$ fertilization will increase asymbiotic $\mathrm{N}_{2}$ fixation rates because of the reduction of the inhibitory effect of $\mathrm{N}$.

(c) Lower fertilization will reduce leaching losses because of lower nutrient inputs.

2. Mechanical weeding will increase the understory vegetation cover, improving soil fertility because of higher organic matter contents and higher nutrient retention from the vegetation's roots.

(a) Higher organic matter will sustain larger microbial biomass and larger soil$\mathrm{N}$ cycling rates.

(b) Higher organic matter will sustain N-fixing bacteria and higher asymbiotic $\mathrm{N}_{2}$ fixation rates.

(c) Higher root density will improve nutrient retention, thus decreasing nutrient leaching losses.

3. Management zones will differ in soil properties. The palm circle will have higher soil nutrient contents because of fertilization. The frond-stacked area will have higher soil organic $\mathrm{C}$ and moderate soil nutrient contents because of litter decomposition.

(a) Higher organic matter in the frond-stacked area will sustain higher microbial biomass and larger soil-N cycling rates in this zone.

(b) Higher $\mathrm{N}$ contents in the palm circle, and to some extent in the frond-stacked area, will result in lower $\mathrm{N}_{2}$ fixation rates than the inter-row because of the $\mathrm{N}$-inhibitory effect.

(c) High nutrient inputs in the palm circle, and to some extent in the frondstacked area, will result in high nutrient leaching losses. 


\section{References}

- Allen K, Corre MD, Kurniawan S, Utami SR, Veldkamp E (2016) Spatial variability surpasses land-use change effects on soil biochemical properties of converted lowland landscapes in Sumatra, Indonesia. Geoderma 284:42-50.

doi:10.1016/j.geoderma.2016.08.010

- Allen K, Corre MD, Tjoa A, Veldkamp E (2015) Soil nitrogen-cycling responses to conversion of lowland forests to oil palm and rubber plantations in Sumatra, Indonesia. PloS One 10(7):e0133325. doi:10.1371/journal.pone.0133325

- Anuar AR, Goh KJ, Heoh TB, Ahmed OH (2008) Spatial variability of soil inorganic $\mathrm{N}$ in a mature oil palm plantation in Sabah, Malaysia. American Journal of Applied Sciences 5(9):1239-1246. doi:10.3844/ajassp.2008.1239.1246

- Ashton-Butt A, Aryawan AAK, Hood ASC, Naim M, Purnomo D, Suhardi, Wahyuningsih R, Willcock S, Poppy GM, Caliman J-P, Turner EC, Foster WA, Peh KSH, Snaddon JL (2018) Understory vegetation in oil palm plantations benefits soil biodiversity and decomposition rates. Frontiers in Forests and Global Change 1:1-13. doi:10.3389/ffgc.2018.00010

- Barnes AD, Allen K, Kreft H, Corre MD, Jochum M, Veldkamp E, Clough Y, Daniel R, Darras K, Denmead LH, Farikhah Haneda N, Hertel D, Knohl A, Kotowska MM, Kurniawan S, Meijide A, Rembold K, Edho Prabowo W, Schneider D, Tscharntke T, Brose U (2017) Direct and cascading impacts of tropical land-use change on multi-trophic biodiversity. Nature Ecology and Evolution 1(10):1511-1519. doi:10.1038/s41559-017-0275-7

- Barron AR, Wurzburger N, Bellenger JP, Wright SJ, Kraepiel AML, Hedin LO (2009) Molybdenum limitation of asymbiotic nitrogen fixation in tropical forest soils. Nature Geoscience 2(1):42-45. doi:10.1038/ngeo366

- Berkelmann D, Schneider D, Engelhaupt M, Heinemann M, Christel S, Wijayanti M, Meryandini A, Daniel R (2018) How rainforest conversion to agricultural systems in Sumatra (Indonesia) affects active soil bacterial communities. Frontiers in Microbiology 9:2381. doi:10.3389/fmicb.2018.02381

- Bigelow SW, Ewel JJ, Haggar JP (2004) Enhancing nutrient retention in tropical tree plantations: no short cuts. Ecological Applications 14(1):28-46

- Bomfim B, Silva LCR, Doane TA, Horwath WR (2019) Interactive effects of land-use change and topography on asymbiotic nitrogen fixation in the Brazilian Atlantic Forest. Biogeochemistry 142(1): 137-153. doi:10.1007/s10533-018-0525-z 
- Carron MP, Auriac Q, Snoeck D, Villenave C, Blanchart E, Ribeyre F, Marichal R, Darminto M, Caliman JP (2015) Spatial heterogeneity of soil quality around mature oil palms receiving mineral fertilization. European Journal of Soil Biology 66:24-31. doi:10.1016/j.ejsobi.2014.11.005

- Carter C, Finley W, Fry J, Jackson D, Willis L (2007) Palm oil markets and future supply. European Journal of Lipid Science and Technology 109(4):307-314. doi:10.1002/ejlt.200600256

- Clough Y, Krishna VV, Corre MD, Darras K, Denmead LH, Meijide A, Moser S, Musshoff O, Steinebach S, Veldkamp E, Allen K, Barnes AD, Breidenbach N, Brose U, Buchori D, Daniel R, Finkeldey R, Harahap I, Hertel D, Holtkamp AM, Hörandl E, Irawan B, Jaya INS, Jochum M, Klarner B, Knohl A, Kotowska MM, Krashevska V, Kreft H, Kurniawan S, Leuschner C, Maraun M, Melati DN, Opfermann N, Pérez-Cruzado C, Prabowo WE, Rembold K, Rizali A, Rubiana R, Schneider D, Tjitrosoedirdjo SS, Tjoa A, Tscharntke T, Scheu S (2016) Land-use choices follow profitability at the expense of ecological functions in Indonesian smallholder landscapes. Nature Communications 7:13137. doi:10.1038/ncomms13137 - Comte I, Colin F, Whalen JK, Grünberger O, Caliman J-P (2012) Agricultural practices in oil palm plantations and their impact on hydrological changes, nutrient fluxes and water quality in Indonesia. Advances in Agronomy 116:71-124. doi:10.1016/B978-0-12-394277-7.00003-8

- Corley RHV (2009) How much palm oil do we need? Environmental Science \& Policy 12(2): 134-139. doi:10.1016/j.envsci.2008.10.011

- Corley RHV, Tinker PB (2016) The oil palm, 5th ed. John Wiley \& Sons, Ltd, Hoboken, NJ

- Corre MD, Dechert G, Veldkamp E (2006) Soil nitrogen cycling following montane forest conversion in central Sulawesi, Indonesia. Soil Science Society of America Journal 70:359-366. doi:10.2136/sssaj2005.0061

- Crews TE, Farrington H, Vitousek PM (2000) Changes in asymbiotic, heterotrophic nitrogen fixation on leaf litter of Metrosideros Polymorpha with long-term ecosystem development in Hawaii. Ecosystems 3(4):386-395. doi:10.1007/s100210000034

- Darras KFA, Corre MD, Formaglio G, Tjoa A, Potapov A, Brambach F, Sibhatu KT, Grass I, Rubiano AA, Buchori D, Drescher J, Fardiansah R, Hölscher D, Irawan B, Kneib T, Krashevska V, Krause A, Kreft H, Li K, Maraun M, Polle A, Ryadin AR, Rembold K, Stiegler C, Scheu S, Tarigan S, Valdés-Uribe A, Yadi S, Tscharntke T, Veldkamp E (2019) Reducing fertilizer and avoiding herbicides in oil palm plantations-ecological and economic valuations. Frontiers in Forests and Global 
Change 2. doi:10.3389/ffgc.2019.00065

- Davidson EA, Carvalho CJR de, Figueira AM, Ishida FY, Ometto JPHB, Nardoto GB, Sabá RT, Hayashi SN, Leal EC, Vieira ICG, Martinelli LA (2007) Recuperation of nitrogen cycling in Amazonian forests following agricultural abandonment. Nature 447(7147):995-998. doi:10.1038/nature05900

- Davidson EA, Hart SC, Shanks CA, Firestone MK (1991) Measuring gross nitrogen mineralization, and nitrification by $15 \mathrm{~N}$ isotopic pool dilution in intact soil cores. Journal of Soil Science 42:335-349. doi:10.1111/j.1365-2389.1991.tb00413.x - Directorate General of Estate Crop (2017) Tree crop estate statistics of Indonesia 2015 - 2017: palm oil

- Dislich C, Keyel AC, Salecker J, Kisel Y, Meyer KM, Auliya M, Barnes AD, Corre MD, Darras K, Faust H, Hess B, Klasen S, Knohl A, Kreft H, Meijide A, Nurdiansyah F, Otten F, Pe'er G, Steinebach S, Tarigan S, Tölle MH, Tscharntke T, Wiegand K (2017) A review of the ecosystem functions in oil palm plantations, using forests as a reference system. Biological Reviews of the Cambridge Philosophical Society 92:1539-1569. doi:10.1111/brv.12295

- Drescher J, Rembold K, Allen K, Beckschäfer P, Buchori D, Clough Y, Faust H, Fauzi AM, Gunawan D, Hertel D, Irawan B, Jaya INS, Klarner B, Kleinn C, Knohl A, Kotowska MM, Krashevska V, Krishna V, Leuschner C, Lorenz W, Meijide A, Melati D, Nomura M, Pérez-Cruzado C, Qaim M, Siregar IZ, Steinebach S, Tjoa A, Tscharntke T, Wick B, Wiegand K, Kreft H, Scheu S (2016) Ecological and socio-economic functions across tropical land use systems after rainforest conversion. Philosophical Transactions of the Royal Society of London. Series B, Biological sciences 371(1694). doi:10.1098/rstb.2015.0275

- FAO (2018) Food and Agricolture Organization, FAOSTAT. http:/ / faostat.fao.org/site/339/default.aspx. Accessed 30 Mar 2020

- Fargione J, Hill J, Tilman D, Polasky S, Hawthorne P (2008) Land clearing and the biofuel carbon debt. Science 319(5867):1235-1238. doi:10.1126/science.1152747

- Figueiredo RO, Markewitz D, Davidson EA, Schuler AE, Watrin OdS, Silva PdS (2010) Land-use effects on the chemical attributes of low-order streams in the eastern Amazon. Journal of Geophysical Research 115(G04004). doi:10.1029/2009JG001200 - Foster WA, Snaddon JL, Turner EC, Fayle TM, Cockerill TD, Ellwood MDF, Broad GR, Chung AYC, Eggleton P, Khen CV, Yusah KM (2011) Establishing the evidence base for maintaining biodiversity and ecosystem function in the oil palm landscapes of South East Asia. Philosophical Transactions of the Royal Society of London. Series B, Biological sciences 366(1582):3277-3291. doi:10.1098/rstb.2011.0041 
- Guillaume T, Holtkamp AM, Damris M, Brümmer B, Kuzyakov Y (2016) Soil degradation in oil palm and rubber plantations under land resource scarcity. Agriculture, Ecosystems \& Environment 232:110-118. doi:10.1016/j.agee.2016.07.002

- Haron K, Brookes PC, Anderson JM, Zakaria ZZ (1998) Microbial biomass and soil organic matter dynamics in oil palm (Elaeis Guineensis Jacq.) plantations, West Malaysia. Soil Biology and Biochemistry 30(5):547-552. doi:10.1016/S0038-0717(97)00217-4

- Hart SC, Stark JM, Davidson EA, Firestone MK (1994) Nitrogen mineralization, immobilization, and nitrification. Methods of Soil Analysis. Part 2. Soil Science society of America Book Series. Microbiological and Biochemical Properties, Madison, WI, USA

- Hassler E, Corre MD, Kurniawan S, Veldkamp E (2017) Soil nitrogen oxide fluxes from lowland forests converted to smallholder rubber and oil palm plantations in Sumatra, Indonesia. Biogeosciences 14:2781-2798. doi:10.5194/bg-14-2781-2017

- Huddell AM, Galford GL, Tully KL, Crowley C, Palm CA, Neill C, Hickman JE, Menge DNL (2020) Meta-analysis on the potential for increasing nitrogen losses from intensifying tropical agriculture. Global Change Biology 26(3):1-13. doi:10.1111/gcb.14951

- Law MC, Balasundram SK, Husni MHA, Ahmed OH, Haniff Harun M (2009) Spatial variability of soil organic carbon in oil palm: a comparison between young and mature stands. International Journal of Agricultural Research 4(12):402-417 - LeBauer DS, Treseder KK (2008) Nitrogen limitation of net primary productivity in terrestrial ecosystems is globally distributed. Ecology 89(2):371-379.

doi:10.1890/06-2057.1

- Lee JSH, Abood S, Ghazoul J, Barus B, Obidzinski K, Koh LP (2014) Environmental impacts of large-scale oil palm enterprises exceed that of smallholdings in Indonesia. Conservation Letters 7(1):25-33. doi:10.1111/conl.12039

- Lu X, Mao Q, Gilliam FS, Luo Y, Mo J (2014) Nitrogen deposition contributes to soil acidification in tropical ecosystems. Global Change Biology 20(12):3790-3801. doi:10.1111/gcb.12665

- Luke SH, Purnomo D, Advento AD, Aryawan AAK, Naim M, Pikstein RN, Ps S, Rambe TDS, Soeprapto, Caliman J-P, Snaddon JL, Foster WA, Turner EC (2019) Effects of understory vegetation management on plant communities in oil palm plantations in Sumatra, Indonesia. Frontiers in Forests and Global Change 2:1-13. doi:10.3389/ffgc.2019.00033 
- Lungu OI, Dynoodt RF (2008) Acidification from long-term use of urea and its effect on selected soil properties. African Journal of Food, Agriculture, Nutrition and Development 8(1). doi:10.4314/ajfand.v8i1.19180

- Maranguit D, Guillaume T, Kuzyakov Y (2017) Land-use change affects phosphorus fractions in highly weathered tropical soils. Catena 149:385-393. doi:10.1016/j.catena.2016.10.010

- Matson PA, Parton WJ, Power AG, Swift MJ (1997) Agricultural intensification and ecosystem properties. Science 277:504-509. doi:10.1126/science.277.5325.504

- Moradi A, Teh CBS, Goh KJ, Husni MHA, Ishak CF (2014) Decomposition and nutrient release temporal pattern of oil palm residues. Annals of Applied Biology 164:208-219. doi:10.1111/aab.12094

- Nelson PN, Rhebergen T, Berthelsen S, Webb MJ, Banabas M, Oberthür T, Donough CR, Rahmadsyah, Indrasuara K, Lubis A (2011) Soil acidification under oil palm: rates and effects on yield. Better Crops with Plant Food 95(4):22-25

- Ngoze S, Kinyangi J, Lehmann J, Mbugua D, Pell A, Riha S, Verchot L (2008) Nutrient constraints to tropical agroecosystem productivity in long-term degrading soils. Global Change Biology 14(12):2810-2822. doi:10.1111/j.1365-2486.2008.01698.x - Oberthuer T (2012) Best Management Practices (BMP) in oil palm fertilization for sustainable intensification. International Oil Plam Conference, Cartagena, Colombia - Pahan I (2010) Complete guide to oil palm, 8th edn. Penebar Swadaya, Jakarta, Indonesia

- Pardon L, Bessou C, Nelson PN, Dubos B, Ollivier J, Marichal R, Caliman J-P, Gabrielle B (2016) Key unknowns in nitrogen budget for oil palm plantations. A review. Agronomy for Sustainable Development 36(1):20.

doi:10.1007/s13593-016-0353-2

- Pauli N, Donough C, Oberthür T, Cock J, Verdooren R, Rahmadsyah, Abdurrohim G, Indrasuara K, Lubis A, Dolong T, Pasuquin JM (2014) Changes in soil quality indicators under oil palm plantations following application of 'Best Management Practices' in a four-year field trial. Agriculture, Ecosystems \& Environment 195:98-111. doi:10.1016/j.agee.2014.05.005

- Perakis SS, Pett-Ridge JC, Catricala CE (2017) Nutrient feedbacks to soil heterotrophic nitrogen fixation in forests. Biogeochemistry 134(1-2):41-55

- Pirker J, Mosnier A, Kraxner F, Havlík P, Obersteiner M (2016) What are the limits to oil palm expansion? Global Environmental Change 40:73-81. doi:10.1016/j.gloenvcha.2016.06.007 
- Reed SC, Cleveland CC, Townsend AR (2011) Functional ecology of free-living nitrogen fixation: a contemporary perspective. Annual Review of Ecology, Evolution, and Systematics 42(1):489-512. doi:10.1146/annurev-ecolsys-102710-145034

- Reed SC, Townsend AR, Cleveland CC, Nemergut DR (2010) Microbial community shifts influence patterns in tropical forest nitrogen fixation. Oecologia 164(2):521-531. doi:10.1007/s00442-010-1649-6

- Rembold K, Mangopo H, Tjitrosoedirdjo SS, Kreft H (2017) Plant diversity, forest dependency, and alien plant invasions in tropical agricultural landscapes. Biological Conservation 213:234-242. doi:10.1016/j.biocon.2017.07.020

- Savilaakso S, Garcia C, Garcia-Ulloa J, Ghazoul J, Groom M, Guariguata MR, Laumonier Y, Nasi R, Petrokofsky G, Snaddon J, Zrust M (2014) Systematic review of effects on biodiversity from oil palm production. Environmental Evidence 3(1):4. doi:10.1186/2047-2382-3-4

- Schlesinger WH, Bernhardt ES (2013) Biogeochemistry. An analysis of global change, 3rd ed. Academic Press, Waltham, Mass

- Silver WL, Herman DJ, Firestone MK (2001) Dissimilatory nitrate reduction to ammonium in upland tropical forest soils. Ecology 82(9):2410-2416.

doi:10.1890/0012-9658(2001)082[2410:DNRTAI]2.0.CO;2

- Teklu BM, Hailu A, Wiegant DA, Scholten BS, van den Brink PJ (2018) Impacts of nutrients and pesticides from small- and large-scale agriculture on the water quality of Lake Ziway, Ethiopia. Environmental Science and Pollution Research 25(14):13207-13216. doi:10.1007/s11356-016-6714-1

- Tiemann TT, Donough CR, Lim YL, Härdter R, Norton R, Tao HH, Jaramillo R, Satyanarayana T, Zingore S, Oberthür T (2018) Feeding the palm: a review of oil palm nutrition. Advances in Agronomy 152:149-243. doi:10.1016/bs.agron.2018.07.001

- Tilman D, Cassman KG, Matson PA, Naylor R, Polasky S (2002) Agricultural sustainability and intensive production practices. Nature 418(6898):671.

doi:10.1038/nature01014

- van Straaten O, Corre MD, Wolf K, Tchienkoua M, Cuellar E, Matthews RB, Veldkamp E (2015) Conversion of lowland tropical forests to tree cash crop plantations loses up to one-half of stored soil organic carbon. Proceedings of the National Academy of Sciences 112(32):9956-9960. doi:10.1073/pnas.1504628112 - Vijay V, Pimm SL, Jenkins CN, Smith SJ (2016) The impacts of oil palm on recent deforestation and biodiversity loss. PloS One 11(7):e0159668. doi:10.1371/journal.pone.0159668 
- Vitousek PM, Menge DNL, Reed SC, Cleveland CC (2013) Biological nitrogen fixation: rates, patterns and ecological controls in terrestrial ecosystems. Philosophical Transactions of the Royal Society of London. Series B, Biological sciences 368(1621):20130119. doi:10.1098/rstb.2013.0119

- Wang X, Zhao J, Wu J, Chen H, Lin Y, Zhou L, Fu S (2011) Impacts of understory species removal and/or addition on soil respiration in a mixed forest plantation with native species in southern China. Forest Ecology and Management 261(6):1053-1060. doi:10.1016/j.foreco.2010.12.027

- Woittiez LS, van Wijk MT, Slingerland M, van Noordwijk M, Giller KE (2017) Yield gaps in oil palm: a quantitative review of contributing factors. European Journal of Agronomy 83:57-77. doi:10.1016/j.eja.2016.11.002

- Wurzburger N, Bellenger JP, Kraepiel AML, Hedin LO (2012) Molybdenum and phosphorus interact to constrain asymbiotic nitrogen fixation in tropical forests. PloS One 7(3):e33710. doi:10.1371/journal.pone.0033710

- Xiong Y, Xia H, Li Z'a, Cai X'a, Fu S (2008) Impacts of litter and understory removal on soil properties in a subtropical Acacia mangium plantation in China. Plant and Soil 304(1):179-188. doi:10.1007/s11104-007-9536-6 


\section{Chapter 2}

Senesced fronds amend the soil

\section{nitrogen cycle and soil fertility in a}

\section{large-scale oil palm plantation}

Greta Formaglio, Edzo Veldkamp, Muhammad Damris, Aiyen Tjoa, Marife D. Corre 


\section{Abstract}

Intensive management practices in large-scale oil palm plantations can deteriorate nutrient cycling and other soil functions. Thus, there is a need to reduce management intensity without sacrificing productivity. The aim of our study was to investigate the effect of management practices on gross rates of soil-N cycling and soil fertility. In Jambi province, Indonesia, we established a management experiment in a large-scale oil palm plantation to compare conventional practices (i.e. high fertilization rates and herbicide weeding) with reduced management intensity (i.e. reduced fertilization rates and mechanical weeding). Also, we compared the typical management zones characterizing large-scale plantations: palm circle, inter-row and frond-stacked area. After 1.5 years of this experiment, reduced and conventional management showed comparable gross soil-N-cycling rates; however, there were stark differences among management zones. The frond-stacked area had higher soil-N-cycling rates and soil fertility (high microbial biomass, available organic $\mathrm{C}$, soil organic $\mathrm{C}$, extractable organic $\mathrm{N}$, total $\mathrm{N}$ and low bulk density) than inter-row and palm circle (all $p \leq 0.05$ ). Microbial biomass was the main driver of the soil $\mathrm{N}$ cycle, attested by its high correlation with gross $\mathrm{N}$ cycling rates $(\mathrm{r}=0.93-0.95, \mathrm{p}<0.01)$. The correlations of microbial $\mathrm{N}$ with available organic $\mathrm{C}$, extractable organic $\mathrm{N}$, soil organic $\mathrm{C}$ and total $\mathrm{N}(\mathrm{r}=0.74-0.87, \mathrm{p}<0.01)$ suggest that microbial biomass was mainly regulated by the availability of organic matter. Mulching with senesced fronds enhanced soil microbial biomass, which promoted nutrient recycling and thereby can decrease dependency on chemical fertilizers. 


\subsection{Introduction}

Palm oil is the world's leading vegetable oil owing to its high yield and low production costs (Carter et al. 2007, Clough et al. 2016). Indonesia is the top producer of palm oil (FAO 2017) with the islands of Sumatra and Kalimantan contributing the largest share (Directorate General of Estate Crop 2017). In Indonesia, 60\% of oil palm plantations are owned by large-scale state and private companies with landholdings ranging from $3000-40000$ ha (Lee et al. 2014), as opposed to smallholder plantations with an average of about 4 ha per household (e.g. Jambi province, Sumatra; Clough et al. 2016).

Management in large-scale oil palm plantations is intensive, characterized by high fertilization rates and weed control using herbicides. Such management is linked to negative environmental impacts, as high $\mathrm{N}$ fertilization rates result in large $\mathrm{N}_{2} \mathrm{O}$ emissions (Hassler et al. 2017) and $\mathrm{N}$ leaching losses (Omoti et al. 1983, Tung et al. 2009), potentially diminishing water quality (Comte et al. 2012), whilst herbicides remove understory vegetation and reduce soil cover, possibly affecting soil biodiversity (Ashton-Butt et al. 2018) and soil erosion (Moradi et al. 2015). Moreover, oil palm plantations have strongly reduced ecosystem functions (e.g. gas and climate regulation, water regulation and filtration, soil fertility, genetic resources) compared to tropical forests (Clough et al. 2016, Dislich et al. 2017). Reduction in management intensity, such as reduced fertilization rate to the level of nutrient export with harvest and mechanical weeding instead of herbicide use, may reduce some of the negative environmental impacts associated with oil palm cultivation and may moderate the decline in some ecosystem functions. Such reductions in fertilization rates are also in line with the direction of the Indonesian government to support precision farming (e.g. varying rates of fertilization with age of plantation, soil types and climate; Ministry of Agriculture of Indonesia, 2016). Moreover, identification of sustainable farming practices is a high priority of the Roundtable for Sustainable Oil Palm (RSPO), a multi- 
stakeholder initiative that includes oil palm companies, financial institutions as well as environmental and social organizations from many countries including Indonesia (RSPO 2018).

Soil-N cycling is an indicator of soil fertility, an important ecosystem function that is very sensitive to management practices (Allen et al. 2015, Corre et al. 2006, Cookson et al. 2006, Lang et al. 2016). The internal soil-N cycle consists of microbialmediated $\mathrm{N}$ transformations that regulate mineral $\mathrm{N}$ production and retention in the soil, determining the soil's capacity to supply N (Davidson et al. 1991, Hart et al. 1994a) as well as its susceptibility to gaseous and N leaching losses (Corre et al. 2014, Kurniawan et al. 2018). An optimal management of the soil-N cycle will maintain crop production and reduce $\mathrm{N}$ losses resulting in both ecological and economic benefits. Agricultural management practices, such as fertilization and weeding, affect soil-Ncycling rates by influencing the inputs of nutrients and organic matter into the soil, and thereby modifying soil biochemical properties and microbial biomass (Allen et al. 2015, 2016, Singh and Ghoshal 2010). Chronic high N fertilization to tropical forest soils reduce soil microbial biomass and $\mathrm{N}$ immobilization rates but increase gross $\mathrm{N}$ mineralization and nitrification rates as well as N-oxide losses (Baldos et al. 2015, Corre et al. 2010, 2014, Koehler et al. 2009, Müller et al. 2015). Furthermore, N addition stimulated gross nitrification rates in tropical tree plantations (Silver et al. 2005). In contrast, herbicide weed control slows down regrowth of understory vegetation by eradicating both above- and belowground biomass, which can lead to reduced organic matter input in the soil and consequently reduced substrate for microbial biomass growth (Mendham et al. 2002). Reductions in organic matter input and soil microbial biomass, as a consequence of forest conversion to oil palm plantation, have led to reduction in gross $\mathrm{N}$ mineralization rate in the soil (Allen et al. 2015). Until now, there has not been a systematic investigation in oil palm plantation on whether reduction in soil-N cycling and soil fertility properties (e.g. soil organic carbon (SOC), total N, microbial biomass, ef- 
fective cation exchange capacity (ECEC), base saturation, bulk density, among others) can be restored by reduction in management intensity.

To investigate soil nutrient cycling in an intensively managed oil palm plantation, it is fundamental to account for the spatial variation caused by the standard management practices (Carron et al. 2015, Haron et al. 1998, Rahman et al. 2018). In most large-scale oil palm plantations, there are three distinct management zones: (1) the area around the palm that is frequently weeded and raked where fertilizer is applied, hereafter called the palm circle; (2) the area between palm rows, which is weeded less frequently to facilitate access to the palms, hereafter called inter-row; and (3) the area where the pruned fronds are piled on every second inter-rows, serving like mulch, hereafter called the frond-stacked area. Decomposition of the fronds can be an important source of nutrients and organic matter to the soil (Frazão et al. 2014, Kotowska et al. 2016), and so the frond-stacked area has a potential to support a substantial microbial biomass (Haron et al. 1998). In the palm circle, where a large part of the oil palms' net primary production is exported via harvest, litter input is mainly from weeding of ground vegetation and from the palm roots that are highly dense within this management zone (Nelson et al. 2006, Schroth et al. 2000), whereas the inter-rows have belowand aboveground litter input mainly from the ground vegetation. These management zones in large-scale oil palm plantation as well as the management intensity can thus drive changes in microbial biomass, soil-N-cycling rates and soil fertility properties. Assessing the link between management practices and soil-N-cycling rates will aid in optimizing capital (e.g. fertilizer) inputs and reduce negative environmental effect, in compliance with RSPO criteria.

In a large-scale oil palm plantation on inherently low-fertility Acrisol soil, we investigated whether management zones differ in gross rates of soil-N cycling and soil fertility properties, and whether 1.5 years of reduced fertilization and mechanical weeding increase soil-N-cycling rates compared to the conventional high fertilization 
rate and herbicide weed control. Our first hypothesis was that the frond-stacked area will have larger available $C$ and microbial biomass, which drive higher rates of soil-N cycling compared to the palm circle (with direct fertilization) and the inter-row (both with low organic matter input). Our second hypothesis was that reduced fertilization and mechanical weeding stimulate soil-N-cycling rates. This hypothesis is based on the above-mentioned studies that chronic high $\mathrm{N}$ fertilization rates depressed microbial biomass in combination with our expectation that this effect would be less if fertilizer rates were reduced. Furthermore, we expected that mechanical weeding will lead to fast ground cover regeneration, which will enhance organic matter input and microbial biomass. We tested our hypotheses by measuring gross rates of soil-N cycling using the ${ }^{15} \mathrm{~N}$ pool dilution techniques in a large-scale, spatially replicated oil palm management experiment.

\subsection{Materials and Methods}

\subsubsection{Site description}

Our study was conducted in a large-scale, state-owned oil palm plantation located in the Batanghari regency, Jambi province, Indonesia ( $1^{\circ} 43^{\prime} 8^{\prime \prime} \mathrm{S}, 103^{\circ} 23^{\prime} 53^{\prime \prime}$ E, elevation of $73 \mathrm{~m}$ above sea level). The plantation encompassed 2025 ha, established between 1998 and 2002, and the palms were 16-20 years old during our study years of 2017-2018. Planting density was approximately 142 palms ha $^{-1}$ with 8 -m spacing between palms within and between rows. Mean annual air temperature in the study area is $26.7 \pm 1.0$ ${ }^{\circ} \mathrm{C}$ and mean annual precipitation is $2235 \pm 385 \mathrm{~mm}$ (1991 - 2011; climate station at the Jambi Sultan Thana airport of the Meteorological, Climatological and Geophysical Agency). Climatic data measured at the plantation from March 2017 to February 2018 showed a mean daily air temperature of $26.3^{\circ} \mathrm{C}$ and an annual precipitation of 2772 $\mathrm{mm}$. In 2013, nutrient depositions through rainfall in the study area were $12.9 \mathrm{~kg} \mathrm{~N}$, 
$0.4 \mathrm{~kg} \mathrm{P}$, and $5.5 \mathrm{~kg} \mathrm{~K} \mathrm{ha}^{-1} \mathrm{yr}^{-1}$ (Kurniawan et al. 2018). The soil in the study area is classified as Acrisol with a loam texture (Allen et al. 2015).

\subsubsection{Experimental design}

In November 2016, a full-factorial management experiment with two fertilization rates and chemical and mechanical weed control was established in order to compare high intensity with low intensity management practices. The experimental layout (Fig. 1) was composed of four blocks as replicates (OM1, OM2, OM3, OM4), each with four plots ( $50 \mathrm{~m} \times 50 \mathrm{~m}$ each) that represented the four treatments: conventional fertilization rate-herbicide (ch), conventional fertilization rate-mechanical weeding $(\mathrm{cw})$, reduced fertilization rate-herbicide (rh), and reduced fertilization rate-mechanical weeding (rw).

Figure 1: Experimental set-up. OM1, OM2, OM3, and OM4 indicate the four blocks, each with the four treatment plots ( $\mathrm{ch}, \mathrm{cw}, \mathrm{rh}$, and rw). Each treatment plot was $50 \mathrm{~m} \times 50 \mathrm{~m}$.

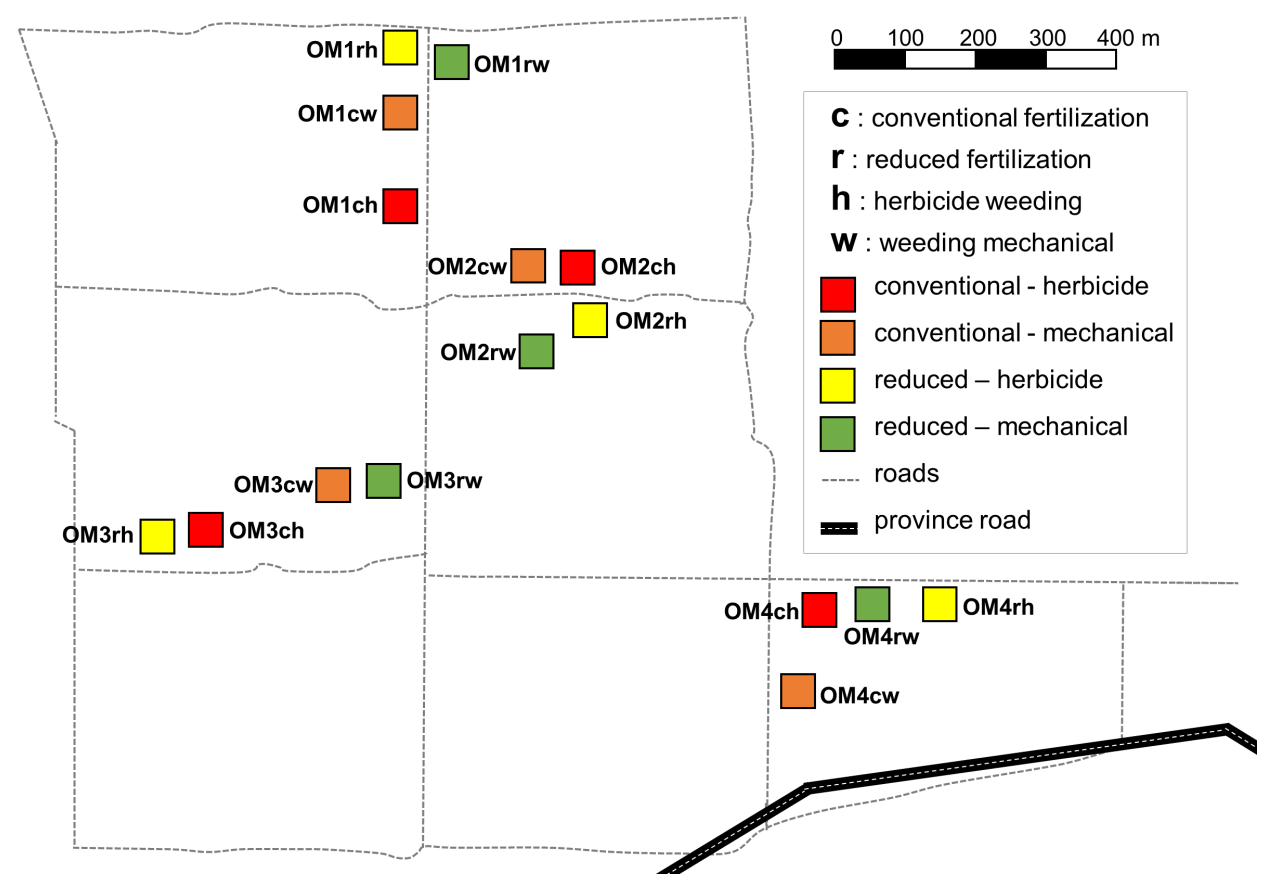

The conventional fertilization rates were based on rates common to large-scale 
plantations on Acrisol soils in Jambi province $\left(260 \mathrm{~kg} \mathrm{~N} \mathrm{ha}^{-1} \mathrm{yr}^{-1}, 50 \mathrm{~kg} \mathrm{P} \mathrm{ha}^{-1} \mathrm{yr}^{-1}\right.$, and $220 \mathrm{~kg} \mathrm{~K} \mathrm{ha}^{-1} \mathrm{yr}^{-1}$ ) whereas the reduced rates were based on the nutrient exports by harvest (136 kg N ha- $\mathrm{yr}^{-1}, 17 \mathrm{~kg} \mathrm{P} \mathrm{ha}^{-1} \mathrm{yr}^{-1}$, and $187 \mathrm{~kg} \mathrm{~K} \mathrm{ha}^{-1} \mathrm{yr}^{-1}$; see below). Fertilizer sources were urea, triple superphosphate and muriate of potash. All treatments received the same rates of lime (426 kg dolomite $\left.\mathrm{ha}^{-1} \mathrm{yr}^{-1}\right)$ and micronutrients (142 kg micro-mag ha ${ }^{-1} \mathrm{yr}^{-1}$ with $0.5 \% \mathrm{~B}_{2} \mathrm{O}_{3}, 0.5 \% \mathrm{CuO}, 0.25 \% \mathrm{Fe}_{2} \mathrm{O}_{3}, 0.15 \% \mathrm{ZnO}, 0.1 \% \mathrm{MnO}$ and $18 \% \mathrm{MgO}$ ), as these were the common rates practiced in large-scale plantations on acidic Acrisol soils (Pahan 2010). Fertilizers were applied in the same way as done in large-scale plantations: rates were split in two applications per year (commonly in April and October), and applied within a 2-m radius of the palm circle after the area was raked.

Weed control was done either by herbicide application (glyphosate), commonly used in large-scale plantations, or by mechanical weeding (using a brush cutter) as reduced management practice. Glyphosate was applied at a rate of $1.5 \mathrm{~L} \mathrm{ha}^{-1} \mathrm{yr}^{-1}$ (split in four applications in a year) to the palm circle, and $0.75 \mathrm{~L} \mathrm{ha}^{-1} \mathrm{yr}^{-1}$ (split in two applications in a year) to the inter-row. Mechanical weed control was carried out using a brush cutter in the same areas and frequencies. The mechanical weeding removed only the aboveground biomass, allowing fast ground cover regeneration, while the herbicide eradicated above- and belowground vegetation parts, resulting to slow regeneration of ground cover (Fig. S1).

Within each plot, we randomly selected one palm from the inner 30-m x 30-m area. We stratified our measurements of gross rates of soil-N cycling according to the three distinct management zones (Figs. 2 and S2): within the palm circle, the interrow and within the frond-stacked area. In total, we measured in 48 sampling points (4 replicate blocks $\times 4$ treatments $\times 3$ management zones) in the study site (Figs. 1 and 2). For measurements of the soil biochemical characteristics, another randomly selected palm was added for soil sampling (Fig. 2). Soil samples from the top 5-cm 
depth were then composited for each management zone per treatment plot, totaling to 48 composite soil samples.

Figure 2: Soil sampling design at each treatment plot. The blue crosses represent the sampling points for the soil-N-cycling measurements and the red crosses represent the additional sampling points for the determination of soil biochemical characteristics.

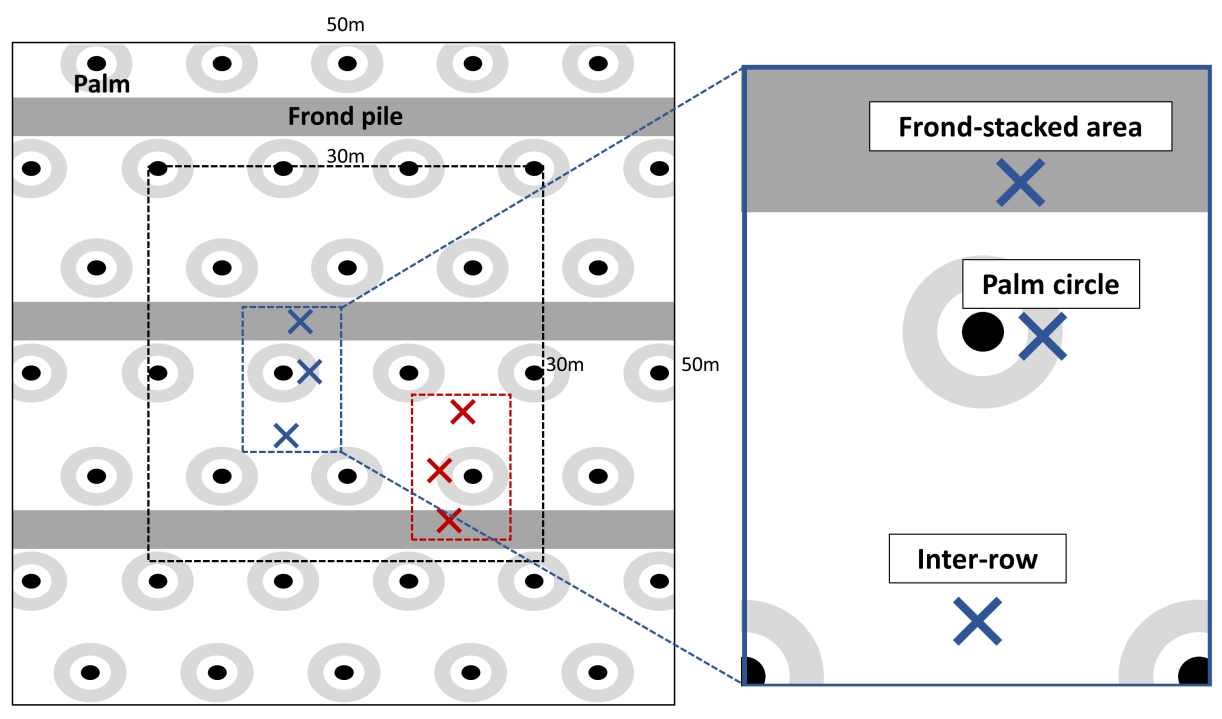

\subsubsection{Calculation of reduced fertilization rates}

The reduced fertilization rates were based on the amount of nutrients $(\mathrm{N}, \mathrm{P}, \mathrm{K})$ exported from the plantation via harvest. To quantify the nutrient exports, we measured nutrient contents in the harvested fruit bunches from the studied plantation prior to the experiment. We selected 20 harvested fruit bunches at the plantation mill, sampled them for fruits and stalks, and made three composite samples for fruits and three composite samples for stalks. We used a subsample to measure gravimetric moisture content, by oven-drying these plant samples at $60^{\circ} \mathrm{C}$ until stable weights were attained (5-7 days); the rest of the samples were oven-dried, ground, and analyzed for total $\mathrm{N}$, $\mathrm{P}$ and $\mathrm{K}$ contents. Total $\mathrm{N}$ contents were determined using a $\mathrm{CN}$ analyzer (Vario EL Cube, Elementar Analysis Systems GmbH, Hanau, Germany). For total P and K contents, samples were pressure-digested in concentrated $\mathrm{HNO}_{3}$, followed by analysis of 
the digests using the inductively coupled plasma-atomic emission spectrometer (ICPAES; iCAP 6300 Duo VIEW ICP Spectrometer, Thermo Fischer Scientific GmbH, Dreieich, Germany). The fruits contained on average $0.5 \mathrm{~g}$ water $\mathrm{g}^{-1}, 0.7 \% \mathrm{~N}, 0.9 \mathrm{mg} \mathrm{P} \mathrm{g}^{-1}$, and $3.8 \mathrm{mg} \mathrm{K} \mathrm{g}^{-1}$; the stalks contained $4.6 \mathrm{~g}$ water $\mathrm{g}^{-1}, 1.1 \% \mathrm{~N}, 1.1 \mathrm{mg} \mathrm{P} \mathrm{g}^{-1}$, and $62.6 \mathrm{mg}$ $\mathrm{K} \mathrm{g}^{-1}$. Based on the long-term yield records of our studied plantation, mean harvest was 11 fruit bunches tree ${ }^{-1} \mathrm{yr}^{-1}$, averaging $23 \mathrm{~kg}$ (fresh weight) per fruit bunch with $70 \%$ fruits and $30 \%$ stalks. Using the measured moisture content of the fruit bunch above and the average planting density (142 trees ha-1 ${ }^{-1}$, the mean yield was $17000 \mathrm{~kg}$ dry fruits ha ${ }^{-1} \mathrm{yr}^{-1}$ and $2000 \mathrm{~kg}$ dry stalks ha-1 $\mathrm{yr}^{-1}$. We multiplied these values with the measured nutrient concentrations to obtain the mean nutrient exports by harvest of $136 \mathrm{~kg} \mathrm{~N}, 17 \mathrm{~kg} \mathrm{P}$, and $187 \mathrm{~kg} \mathrm{~K} \mathrm{ha}^{-1} \mathrm{yr}^{-1}$. These values were used as the basis for the reduced fertilization rates.

\subsubsection{Gross rates of internal soil-N cycling}

We measured the gross rates of soil-N cycling on intact soil cores of the top $5 \mathrm{~cm}$ mineral soil, using the ${ }^{15} \mathrm{~N}$ pool dilution technique with in-situ incubations (Davidson et al. 1991). Measurements were conducted in February 2018, 1.5 years since the start of the experiment and four months after the last fertilization and weeding. We measured all treatments from one block (Fig. 1) on the same day. At each treatment plot, we took five intact soil cores ( $8 \mathrm{~cm}$ diameter and $5 \mathrm{~cm}$ length) at each of the three management zones (Fig. 2). Two cores were injected with five 1-mL $\left({ }^{15} \mathrm{NH}_{4}\right)_{2} \mathrm{SO}_{4}$ solution (containing $27 \mu \mathrm{g} \mathrm{N} \mathrm{mL}^{-1}$ with $95 \%{ }^{15} \mathrm{~N}$ enrichment) to measure gross rates of $\mathrm{N}$ mineralization and microbial $\mathrm{NH}_{4}{ }^{+}$immobilization. Two other cores were injected with five 1-mL K ${ }^{15} \mathrm{NO}_{3}$ solution (containing $28 \mu \mathrm{g} \mathrm{N} \mathrm{mL}{ }^{-1}$ with $95 \%{ }^{15} \mathrm{~N}$ enrichment) to measure gross nitrification, microbial $\mathrm{NO}_{3}{ }^{-}$immobilization and dissimilatory nitrate reduction to ammonium (DNRA). We used the remaining soil core to determine the background levels of $\mathrm{NH}_{4}{ }^{+}$and $\mathrm{NO}_{3}{ }^{-}$in the soil. From each pair of soil cores, one was extracted 
approximately 10 minutes after ${ }^{15} \mathrm{~N}$ injection (T0 cores) while the other intact core was extracted after incubation for one day in a loosely closed plastic bag in the field (T1 cores; Fig. S2). The T0 cores were used to correct for reactions that occur immediately after ${ }^{15} \mathrm{~N}$ injection.

Soil mineral $\mathrm{N}$ extraction from the $\mathrm{T} 0$ and $\mathrm{T} 1$ cores was done by mixing the soil, removing roots, and placing a subsample into a pre-weighed bottle containing $150 \mathrm{~mL} 0.5 \mathrm{~mol} \mathrm{~L}^{-1} \mathrm{~K}_{2} \mathrm{SO}_{4}$ (approximately 1:3 ratio of fresh soil to solution). The bottles were then shaken for 1 hour, and the solution was filtered through pre-washed (with $\left.0.5 \mathrm{~mol} \mathrm{~L}^{-1} \mathrm{~K}_{2} \mathrm{SO}_{4}\right)$ filter papers ( $4 \mu \mathrm{m}$ nominal pore size). The extracts were frozen immediately, stored in a freezer, and transported by airfreight to Germany, where they were analyzed. Gravimetric moisture content was determined from each soil core, by oven-drying at $105{ }^{\circ} \mathrm{C}$ for one day, and was used to calculate the dry mass of soils extracted for mineral $\mathrm{N}$.

Analyses of ${ }^{15} \mathrm{~N}$ from the extracts were done following the ${ }^{15} \mathrm{~N}$ diffusion procedures outlined by Corre and Lamersdorf (2004). The ${ }^{15} \mathrm{~N}$ enrichment was determined using isotope ratio mass spectrometer (IRMS; Delta Plus, Finnigan MAT, Bremen, Germany). The $\mathrm{NH}_{4}{ }^{+}$and $\mathrm{NO}_{3}{ }^{-}$concentrations in the extracts were determined by continuous flow injection colorimetry (SEAL Analytical AA3, SEAL Analytical GmbH, Norderstadt, Germany): $\mathrm{NH}_{4}{ }^{+}$was analyzed via salicylate and dicloroisocyanuric acid reaction (Autoanalyzer Method G-102-93) and $\mathrm{NO}_{3}{ }^{-}$was analyzed with cadmium reduction method with $\mathrm{NH}_{4} \mathrm{Cl}$ buffer (Autoanalyzer Method G-254-02).

We calculated gross rates of soil-N cycling following the equations given by Davidson et al. (1991) and (Hart et al. 1994b). Gross rates of N mineralization and nitrification were calculated from the ${ }^{15} \mathrm{NH}_{4}{ }^{+}$- and ${ }^{15} \mathrm{NO}_{3}$-injected cores, respectively, based on the dilution of ${ }^{15} \mathrm{~N}$ enrichments in the $\mathrm{NH}_{4}{ }^{+}$or $\mathrm{NO}_{3}{ }^{-}$pools between the $\mathrm{T} 0$ and $\mathrm{T} 1$ cores. Microbial $\mathrm{NH}_{4}{ }^{+}$immobilization was calculated as the difference between gross $\mathrm{N}$ mineralization and gross nitrification, while $\mathrm{NO}_{3}{ }^{-}$immobilization was equal 
to $\mathrm{NO}_{3}{ }^{-}$consumption (Davidson et al. 1991). The DNRA rates were calculated from the ${ }^{15} \mathrm{NO}_{3}{ }^{-}$-injected cores following the calculation procedures of Silver et al. (2001). Turnover times of $\mathrm{NH}_{4}{ }^{+}, \mathrm{NO}_{3}{ }^{-}$and microbial biomass $\mathrm{N}$ (see below) were calculated by dividing the pool with the flux rate.

\subsubsection{Soil fertility characteristics}

We determined microbial biomass $\mathrm{C}$ and $\mathrm{N}$ using the fumigation-extraction method (Brookes et al. 1985, Davidson et al. 1991). We took a subsample (about $25 \mathrm{~g}$ fresh soil) from the $\mathrm{T} 1$ cores and fumigated it with $\mathrm{CHCl}_{3}$ for six days, after which the soil was extracted with $0.5 \mathrm{~mol} \mathrm{~L}^{-1} \mathrm{~K}_{2} \mathrm{SO}_{4}$ (approximately 1:5 ratio of fresh soil to solution) as described above. Organic $\mathrm{C}$ concentrations in the extracts were analyzed by ultraviolet-enhanced persulfate oxidation with prior removal of inorganic $C$, using a Total Organic Carbon Analyzer (TOC-Vwp; Shimadzu Europa GmbH, Duisburg, Germany) with an infrared detector. Total $\mathrm{N}$ concentration in the extracts were measured by ultraviolet-persulfate digestion followed by hydrazine sulfate reduction using continuous flow injection colorimetry (see above). Microbial biomass $\mathrm{C}$ and $\mathrm{N}$ were calculated as the difference of organic $\mathrm{C}$ and $\mathrm{N}$ between the fumigated and unfumigated samples, divided by $\mathrm{k}_{\mathrm{C}}=0.45$ for microbial biomass $\mathrm{C}$ and by $\mathrm{k}_{\mathrm{N}}=0.68$ for microbial biomass N with a six-day fumigation (Brookes et al. 1985, Davidson et al. 1991). Also, as an index of available organic $C$, we used the microbial utilized $C$, calculated as the sum of $\mathrm{NH}_{4}{ }^{+}$and $\mathrm{NO}_{3}{ }^{-}$immobilization rates multiplied by the microbial biomass $\mathrm{C}: \mathrm{N}$ ratio (Hart et al. 1994a).

Soil bulk density in the top $5 \mathrm{~cm}$ was measured using the same soil cores, and the values were used to convert the gravimetric moisture content to water-filled pore space, using a soil particle density of $2.65 \mathrm{~g} \mathrm{~cm}^{-3}$. Soil biochemical characteristics were determined from the composite soil samples (taken from the top 5-cm depth) of each management zone at each treatment plot (Fig. 2). Subsamples of the air-dried, sieved (2 
$\mathrm{mm}$ ) soils were finely ground and analyzed for SOC (after removal of inorganic $\mathrm{C}$, e.g. palm circle, by acid fumigation; Harris et al. 2001) and total $\mathrm{N}$ concentrations using a $\mathrm{CN}$ analyzer and for ${ }^{15} \mathrm{~N}$ natural abundance signatures using IRMS (described above). The air-dried and sieved soils were used to measure $\mathrm{pH}$ in a 1:4 soil-to-water ratio, and ECEC by percolating the soils with unbuffered $1 \mathrm{~mol} \mathrm{~L}^{-1} \mathrm{NH}_{4} \mathrm{Cl}$ and measuring the cations ( $\mathrm{Ca}, \mathrm{Mg}, \mathrm{K}, \mathrm{Na}, \mathrm{Al}, \mathrm{Fe}, \mathrm{Mn}$ ) in percolates using ICP-AES. Finally, we measured the ${ }^{15} \mathrm{~N}$ natural abundance signatures of the decomposing fronds in the frond-stacked area; we took four litter samples per plot, divided into leaflets and rachis, and the ${ }^{15} \mathrm{~N}$ natural abundance was analyzed from dried and ground samples using IRMS.

\subsubsection{Statistical analysis and comparison with smallholder oil palm plantations and forest as the reference land use}

We first checked each parameter for homogeneity of variance using Levene's test and log-transformed them in case of unequal variance. Normal distribution was tested with the Shapiro-Wilk test and differences among treatments or management zones were tested using one-way analysis of variance with Tukey HSD test for multiple comparisons. For the parameters that showed non-normal distributions, differences among treatments or management zones were tested using Kruskal-Wallis $\mathrm{H}$ test followed by the multiple comparison extension test. To assess the relationships of soil-Ncycling rates with soil biochemical parameters, we used Spearman rank correlation test on the mean of the four replicate blocks per treatment, separated for each management zone ( $\mathrm{n}=12 ; 4$ treatments $\times 3$ management zones). All statistical tests were considered significant at $\mathrm{p} \leq 0.05$, except for microbial $\mathrm{N}$ for which we considered a marginal significance at $p=0.07$. All statistical analyses were carried out using $R$ version 3.5.1 ( $R$ Core Team 2019).

To gain additional insights on soil-N cycling with changes in management intensity and land use, we compared the soil-N-cycling rates from our present large-scale 
oil palm plantation with those measured in smallholder oil palm plantations and lowland forest sites (as the reference land use), reported by Allen et al. (2015), located in the same climatic area and soil type as our large-scale plantation site. This earlier work from our group used the same ${ }^{15} \mathrm{~N}$ pool dilution techniques for the same soil depth (top $5 \mathrm{~cm}$ ) and similar measurement season (January-March 2013, rainy season) as in our present study. Smallholder oil palm plantations have lower management intensity (i.e. fertilization rates ranged from 48-88 kg N, 21-38 $\mathrm{kg} \mathrm{P}$ and 40-73 $\mathrm{kg} \mathrm{K} \mathrm{ha}^{-1} \mathrm{yr}^{-1}$; Allen et al. 2015) and the frond-stacked area is not spatially distinct as in our large-scale plantation. To compare our present measurements of soil-N-cycling rates in the large-scale plantation with those from the smallholder plantations, we averaged the rates from the palm circle and inter-row per treatment plot. The frond-stacked area was analyzed separately because frond-stacked areas were indistinguishable in the smallholder plantations. We converted the soil-N-cycling rates from soil mass basis $\left(\mathrm{mg} \mathrm{N} \mathrm{kg}^{-1}\right.$ soil d-1) to area basis $\left(\mathrm{mg} \mathrm{N} \mathrm{m}^{-2} \mathrm{~d}^{-1}\right)$ using the measured soil bulk density, averaged for each management zone. We used the same statistical tests mentioned above.

\subsection{Results}

\subsubsection{Gross rates of soil-N cycling}

After 1.5 year from the start of the management treatments, we did not detect any differences in soil-N-cycling processes among the experimental treatments, stratified according to management zone ( $\mathrm{p}>0.05$; Table 1). One exception was $\mathrm{NH}_{4}{ }^{+}$immobilization in the frond-stacked area, which was lower in the rw than in the cw and rh treatments ( $\mathrm{p} \leq 0.04$; Table 1 ). We attributed this difference to a high proportion of gross nitrification relative to gross $\mathrm{N}$ mineralization in the rw treatment, resulting in low $\mathrm{NH}_{4}{ }^{+}$immobilization (Table 1).

In contrast, we detected clear differences in soil-N-cycling rates among manage- 
ment zones, especially between the frond-stacked area and the other two zones (Table 1). Gross $\mathrm{N}$ mineralization, gross nitrification, and $\mathrm{NH}_{4}{ }^{+}$and $\mathrm{NO}_{3}{ }^{-}$immobilization rates were larger in the frond-stacked area compared to the palm circle and inter-row (all $\mathrm{p}<0.01$ ), and gross $\mathrm{N}$ mineralization was higher in the inter-row compared to the palm circle $(p=0.01$; Table 1$)$. The DNRA rates were higher in the palm circle than in the inter-row ( $p=0.05$; Table 1$)$, but they were generally low, ranging only from $3 \%$ (frond-stacked area) to $16 \%$ (palm circle) of the gross nitrification. Thus, microbial $\mathrm{NO}_{3}{ }^{-}$immobilization was the main $\mathrm{NO}_{3}{ }^{-}$retention process. In the frond-stacked area, most of the produced $\mathrm{NH}_{4}{ }^{+}$was used for microbial $\mathrm{NH}_{4}{ }^{+}$immobilization, whereas in the palm circle and inter-row the importance of both $\mathrm{NH}_{4}{ }^{+}$immobilization and gross nitrification as fates of produced $\mathrm{NH}_{4}{ }^{+}$were comparable (Table 1). The turnover times were comparable among management zones, averaging $0.23 \pm 0.03$ days for $\mathrm{NH}_{4}{ }^{+}$, $0.34 \pm 0.08$ days for $\mathrm{NO}_{3}{ }^{-}$and $7.8 \pm 0.5$ days for the microbial $\mathrm{N}$ pool. Across treatments and management zones, gross $\mathrm{N}$ mineralization and gross nitrification were correlated $(\mathrm{r}=0.86, \mathrm{p}<0.01, \mathrm{n}=12)$. DNRA did not show any correlation, either with $\mathrm{N}$-cycling processes or with soil fertility parameters (all $\mathrm{p}>0.05$ ).

Compared to the smallholder plantations, gross rates of mineral $\mathrm{N}$ production and immobilization were larger in the frond-stacked area of the large-scale plantation (all $\mathrm{p} \leq 0.03$; Fig. 3), while the inter-row and palm circle of the large-scale plantation had comparable soil-N-cycling rates as those in the smallholder plantations (Fig. 3). Mineral N production in the frond-stacked area was twice the rates of the forest, which also drove the larger microbial $\mathrm{N}$ immobilization rates in the frond-stacked area than the forest ( $\mathrm{p}<0.01$; Fig. 3). DNRA was higher in the forest than in the frond-stacked area $(\mathrm{p}=0.02)$; however, this process of $\mathrm{N}$ retention (by converting $\mathrm{NO}_{3}{ }^{-}$to less mobile $\mathrm{NH}_{4}{ }^{+}$) was consistently lower than $\mathrm{NO}_{3}{ }^{-}$immobilization in all land uses (Fig. 3). 
Chapter 2. Soil nitrogen cycle

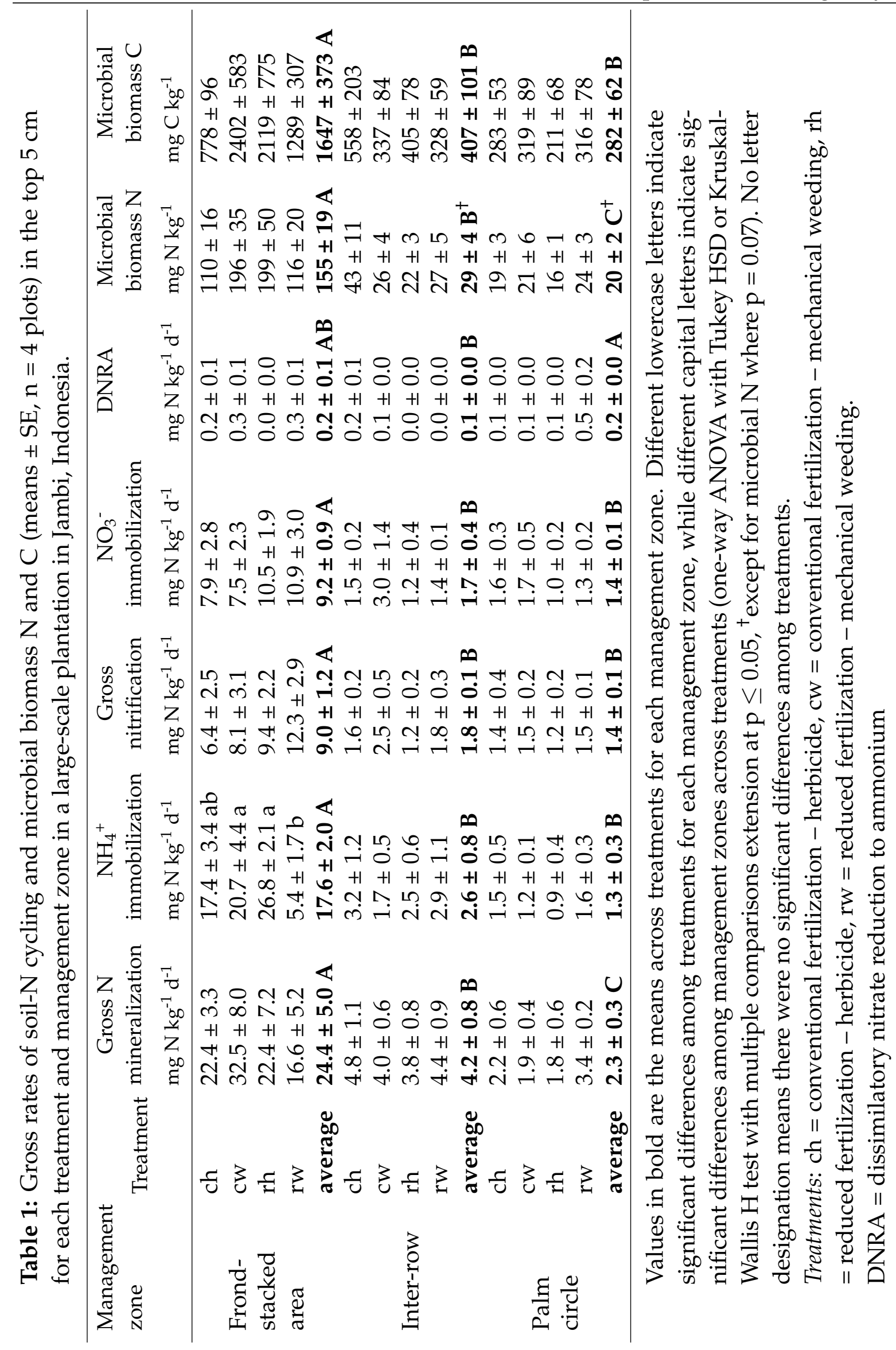


Figure 3: Mean ( $\pm \mathrm{SE}, \mathrm{n}=4$ plots) gross rates of soil-N cycling $\left(\mathrm{mg} \mathrm{N} \mathrm{m}^{-2} \mathrm{~d}^{-1}\right)$, and $\mathrm{N}$ pools ( $\mathrm{mg} \mathrm{N} \mathrm{m}^{-2}$, in black boxes), measured in the top 5-cm depth, in large-scale and smallholder oil palm plantations and lowland forest (the latter taken from Allen et al. 2015), all on loam Acrisol soils in Jambi, Indonesia

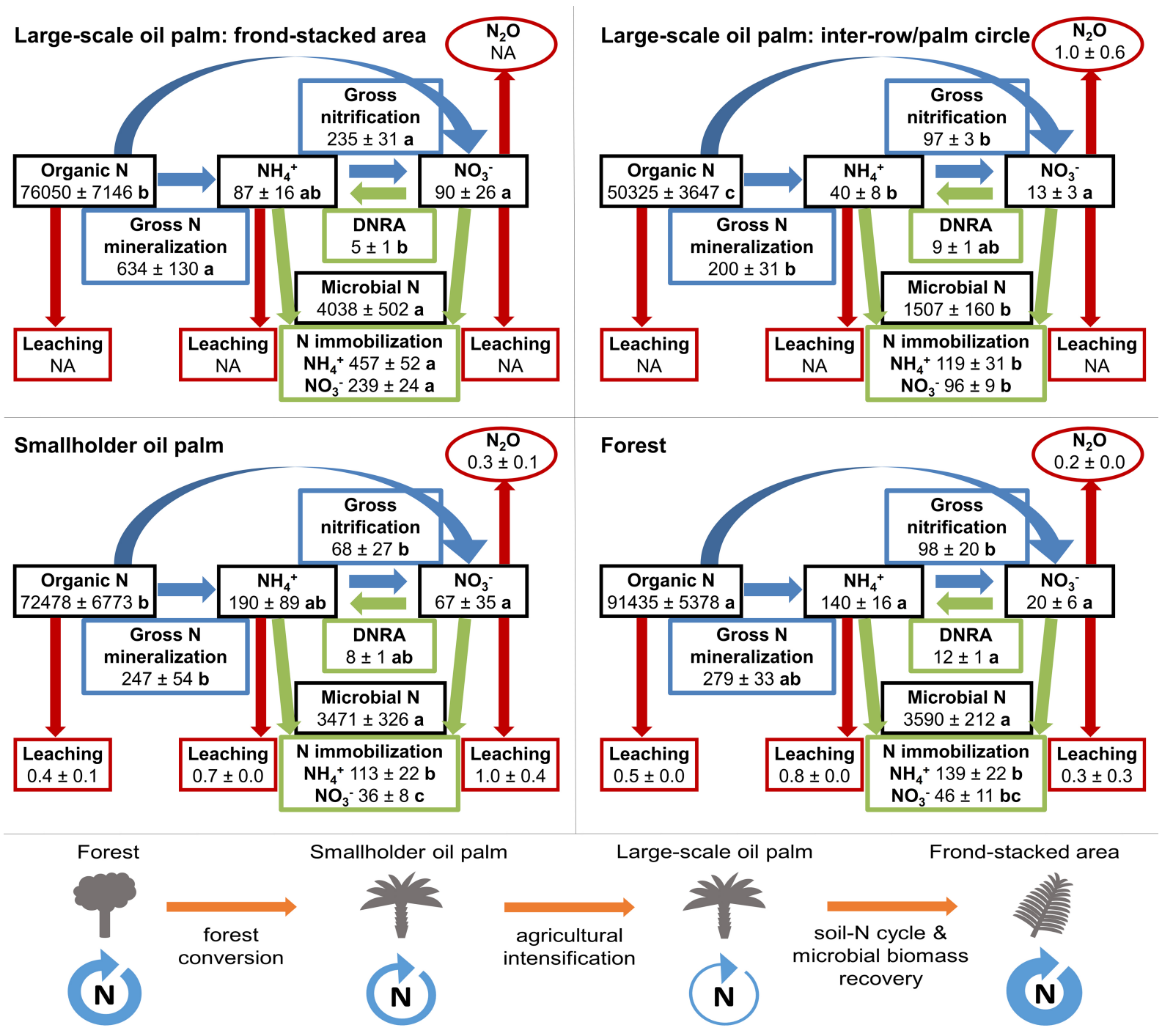

Blue arrows represent soil-N production processes, green arrows represent soil-N retention processes, and red arrows represent soil-N losses. For each parameter, different letters indicate significant differences among land uses (one-way ANOVA with Tukey HSD or Kruskal-Wallis $\mathrm{H}$ test with multiple comparison extension at $\mathrm{p} \leq 0.05$ ).

Soil $\mathrm{N}_{2} \mathrm{O}$ emissions ( $\left.\mathrm{mg} \mathrm{N} \mathrm{m}^{-2} \mathrm{~d}^{-1}\right)$ and $\mathrm{N}$ leaching losses $\left(\mathrm{mg} \mathrm{N} \mathrm{m}^{-2} \mathrm{~d}^{-1}\right.$, measured at 1.5-m depth) were reported by Hassler et al. (2017) and Kurniawan et al. (2018), respectively; NA - not available. 


\subsubsection{Soil fertility characteristics}

Soil fertility parameters in the top $5 \mathrm{~cm}$ did not show any treatment effect (all $\mathrm{p}>$ 0.05 ) but clearly differed among management zones. Microbial biomass $\mathrm{N}$ followed a similar trend as gross $\mathrm{N}$ mineralization: higher in the frond-stacked area compared to the other management zones $(\mathrm{p}<0.01)$ and lower in the palm circle than in the inter-row ( $p=0.07$; Table 1). Microbial biomass $C$ was also higher in the frond-stacked area than in the other zones $(\mathrm{p}<0.01$; Table1) and microbial biomass C:N ratio (14 \pm 4 ) did not differ among management zones $(\mathrm{p}=0.26)$. The frond-stacked area had higher available organic $\mathrm{C}$, extractable organic $\mathrm{N}, \mathrm{SOC}$, total N, and ECEC compared to the other zones (all $p \leq 0.04$ ), whereas the palm circle showed higher ECEC than the inter-row ( $\mathrm{p}<0.01$; Table 2 ). The palm circle also had a higher base saturation and $\mathrm{pH}$ compared to the other zones (both $\mathrm{p}<0.01$ ) whereas the frond-stacked area had higher base saturation than the inter-row $(\mathrm{p}=0.02)$ but comparable $\mathrm{pH}(\mathrm{p}=0.44$; Table 2).

Soil bulk density was lower in the frond-stacked area than the other zones $(\mathrm{p}<$ $0.01)$ whereas this was comparable between the palm circle and inter-row $(p=0.89)$. The water-filled pore space and soil temperature showed little variation and were comparable among zones (all $\mathrm{p}>0.05$; Table 2). Soil ${ }^{15} \mathrm{~N}$ natural abundance was lower in the frond-stacked area $(\mathrm{p}<0.01)$ than the other zones whereas the palm circle and inter-row showed comparable values $(\mathrm{p}=0.11$; Table 2$)$. The leaf litter in the frondstacked area was depleted in ${ }^{15} \mathrm{~N}$ natural abundance with higher values for the leaflets than the rachis (Table 2).

Mineral $\mathrm{N}$ production rates (mineralization and nitrification) in the soil were strongly correlated with microbial biomass $\mathrm{N}(\mathrm{r}=0.93-0.95$, all $\mathrm{p}<0.01, \mathrm{n}=12)$ which, in turn, was positively correlated with available organic $\mathrm{C}$ and extractable organic $\mathrm{N}$ $(\mathrm{r}=0.74-0.87, \mathrm{p}<0.01, \mathrm{n}=12)$ and negatively correlated with the soil ${ }^{15} \mathrm{~N}$ natural 
abundance signatures $(\mathrm{r}=-0.85, \mathrm{p}<0.01, \mathrm{n}=12)$. Available organic $\mathrm{C}$ and extractable organic $\mathrm{N}$ were also correlated with soil organic $\mathrm{C}$ and total $\mathrm{N}(\mathrm{r}=0.76-0.78, \mathrm{p}<0.01$, $\mathrm{n}=12)$, of which the latter were correlated with ECEC $(\mathrm{r}=0.60-0.77, \mathrm{p} \leq 0.04, \mathrm{n}=12)$.

Table 2: Soil fertility and physical characteristics (means $\pm \mathrm{SE}, \mathrm{n}=4$ plots) measured in the top $5 \mathrm{~cm}$ at the different management zones in a large-scale oil palm plantation in Jambi, Indonesia.

\begin{tabular}{|c|c|c|c|}
\hline Characteristics & $\begin{array}{l}\text { Frond- } \\
\text { stacked } \\
\text { area }\end{array}$ & Inter-row & Palm circle \\
\hline Available organic $\mathrm{C}\left(\mathrm{mg} \mathrm{C} \mathrm{kg}^{-1} \mathrm{~d}^{-1}\right)$ & $279 \pm 54 \mathrm{a}$ & $51 \pm 7 b$ & $42 \pm 12 b$ \\
\hline Extractable organic $\mathrm{N}\left(\mathrm{mg} \mathrm{N} \mathrm{kg}^{-1}\right)$ & $15.5 \pm 2.2 \mathrm{a}$ & $6.5 \pm 0.6 b$ & $3.9 \pm 0.3 b$ \\
\hline Soil organic $\mathrm{C}\left(\mathrm{g} \mathrm{C} \mathrm{kg}^{-1}\right)$ & $47.6 \pm 5.3 \mathrm{a}$ & $12.2 \pm 0.6 \mathrm{~b}$ & $11.9 \pm 1.4 \mathrm{~b}$ \\
\hline Total N $\left(\mathrm{g} \mathrm{N} \mathrm{kg}^{-1}\right)$ & $2.9 \pm 0.3 \mathrm{a}$ & $0.9 \pm 0.1 \mathrm{~b}$ & $0.8 \pm 0.1 \mathrm{~b}$ \\
\hline Soil C:N ratio & $16.0 \pm 0.3 \mathrm{a}$ & $14.1 \pm 0.2 \mathrm{~b}$ & $15.1 \pm 0.3 \mathrm{ab}$ \\
\hline $\operatorname{ECEC~}\left(\mathrm{mmol}_{\mathrm{C}} \mathrm{kg}^{-1}\right)$ & $113 \pm 13 \mathrm{a}$ & $22 \pm 2 c$ & $72 \pm 7 b$ \\
\hline Base saturation (\%) & $96 \pm 1 \mathrm{~b}$ & $59 \pm 6 c$ & $100 \pm 0 \mathrm{a}$ \\
\hline $\mathrm{pH}\left(1: 4 \mathrm{H}_{2} \mathrm{O}\right)$ & $5.33 \pm 0.12 b$ & $5.17 \pm 0.06 \mathrm{~b}$ & $6.51 \pm 0.05 \mathrm{a}$ \\
\hline Bulk density $\left(\mathrm{g} \mathrm{cm}^{-3}\right)$ & $0.52 \pm 0.06 \mathrm{a}$ & $1.20 \pm 0.04 \mathrm{~b}$ & $1.23 \pm 0.04 \mathrm{~b}$ \\
\hline Water filled pore space $(\%)$ & $36.6 \pm 1.3 a$ & $34.6 \pm 1.1 \mathrm{a}$ & $31.5 \pm 0.8 \mathrm{a}$ \\
\hline Temperature $\left({ }^{\circ} \mathrm{C}\right)$ & $26.0 \pm 0.3 \mathrm{a}$ & $25.5 \pm 0.4 \mathrm{a}$ & $25.8 \pm 0.5 \mathrm{a}$ \\
\hline Soil $\delta^{15} \mathrm{~N}$ natural abundance $(\%)$ & $2.3 \pm 0.3 b$ & $4.3 \pm 0.2 \mathrm{a}$ & $5.0 \pm 0.1 \mathrm{a}$ \\
\hline Leaf litter $\delta^{15} \mathrm{~N}$ natural abundance $(\%)$ & \multicolumn{3}{|c|}{$\begin{array}{l}\text { leaflets }-0.2 \pm 0.5 \\
\text { rachis }-1.6 \pm 0.3\end{array}$} \\
\hline
\end{tabular}

For each parameter, different letters indicate significant differences among management zones (one-way ANOVA with Tukey HSD or Kruskal-Wallis H test with multiple comparisons extension at $\mathrm{p} \leq 0.05$ ).

Available organic $\mathrm{C}=$ total $\mathrm{N}$ immobilization $\mathrm{x}$ microbial $\mathrm{C}: \mathrm{N}$ ratio.

$\mathrm{ECEC}=$ effective cation exchange capacity. 


\subsection{Discussion}

\subsubsection{Differences among management zones and effect of manage- ment practices}

The clear differences among management zones, specifically the frond-stacked area with large soil-N-cycling rates, microbial biomass (Table 1), available organic $\mathrm{C}$, SOC, total $\mathrm{N}$ and ECEC (Table 2), supported our first hypothesis. Other studies in large-scale oil palm plantations in Southeast Asia, with similar age as our studied plantation, reported that the frond-stacked area had higher microbial biomass, SOC and N contents (although soil-N cycling was not measured) compared to the other management zones (Haron et al.,1998). Other studies, however, did not detect differences in SOC and N contents between management zones (Tao et al. 2016) or even found higher SOC in the palm circle compared to the frond-stacked area (Carron et al. 2015). In our study site as well as in the study by Haron et al. (1998), the senesced fronds were piled on the inter-row whereas in studies that found contrasting results (Tao et al. 2016, Carron et al. 2015) the fronds were distributed around the palms. The latter practice, however, is uncommon in oil palm plantations in Jambi province, as it hinders easy access to the palms during harvesting.

At our site, high SOC and total $\mathrm{N}$ in the frond-stacked area were corroborated by high available organic $\mathrm{C}$ and extractable $\mathrm{N}$ (Table 2), altogether due to the large organic matter input from decomposing fronds. The low bulk density in the frondstacked area (Table 2) was also in line with the high organic matter contents (Table 2). Approximately $9.8 \mathrm{Mg}$ dry matter $\mathrm{ha}^{-1} \mathrm{yr}^{-1}$ of pruned fronds are stacked in this area at a rate of 20-24 fronds tree ${ }^{-1} \mathrm{yr}^{-1}$ (Aljuboori 2013; Corley and Tinker 2016). The regular addition of senesced fronds on the frond-stacked area was also reflected in its low soil ${ }^{15} \mathrm{~N}$ natural abundance (Table 2 ) as the senesced palm fronds were depleted 
in ${ }^{15} \mathrm{~N}$ (Table 2), which reflects the low ${ }^{15} \mathrm{~N}$ natural abundance signature of the applied urea taken up by the palms (-2.2 $\pm 0.03 \%$; Corre et al. 2010). The correlation of SOC and total $\mathrm{N}$ with ECEC showed the importance of organic matter as a main contributor to the ECEC (particularly for the frond-stacked area) of highly weathered Acrisol soils (Sanchez and Logan 1992). In other studies, mulching the soil with empty fruit bunches from palm oil processing has also improved soil biochemical characteristics (Abu Bakar et al. 2011, Tao et al. 2016). These results showed that mulching with senesced fronds in the frond-stacked areas of plantations, instead of exporting or burning them, can recover soil-N cycling and fertility (i.e. increases in microbial biomass, SOC, total N, ECEC and base saturation) in this otherwise inherently nutrient poor, Acrisol soils (Allen et al. 2016).

Contrary to our second hypothesis, we did not detect any effect of the management intensity treatments on soil-N-cycling rates (Table 1) and soil fertility characteristics. This may be due to the fact that the reduced management still added a substantial amount of nutrients to sustain high production. Also, the reduced management was established only 1.5 years before we conducted our measurements as opposed to the prior conventional management that had already been employed since the plantation establishment in the last 16-20 years. Similarly, an experiment on understory vegetation manipulation in a large-scale oil palm plantation in Riau province, Indonesia, did not show any effect on soil characteristics after two years of treatment (Ashton-Butt et al. 2018). Other studies that investigated effects of nutrient manipulation on soil $\mathrm{N}$ cycle in the tropics did not detect effects after one year of treatment (Corre et al. 2010, Silver et al. 2005) but only after 3-4 years (Baldos et al. 2015, Corre et al. 2014) and more clearly after 9-11 years (Corre et al. 2010, Hall and Matson 1999). Therefore, we expect that treatment effects on soil nutrient cycling and fertility characteristics may emerge only after this management experiment has continued for several more years. Also, the first two years of our management intensity manipulation did not result in yield 
difference among treatments (Darras et al. 2019); however, a long-term effect on yield is fundamental to evaluate the profitability of the reduced management practices.

\subsubsection{Controls on soil N cycle and comparison with smallholder plan- tations and forests}

Microbial biomass amount was the main driver of the soil $\mathrm{N}$ cycle in our studied plantation, as indicated by the strong correlation of soil-N-cycling rates with microbial biomass $\mathrm{N}$. The correlations of microbial $\mathrm{N}$ with available organic $\mathrm{C}$ and extractable organic N, as well as with SOC and total N, suggest that microbial biomass was mainly regulated by the input of organic matter. Other studies on litter manipulations have reported a reduction in microbial biomass with litter removal from tropical forests (Leff et al. 2012, Sayer et al. 2007) and tree plantations (Li et al. 2004, Mendham et al. 2002). The high soil ${ }^{15} \mathrm{~N}$ natural abundance in the palm circle and inter-row (Table 2) signified a highly decomposed organic matter as a consequence of reduced litter inputs in these zones (Craine et al. 2015), which resulted in lower microbial biomass and soil$\mathrm{N}$-cycling rates compared to the frond-stacked area (Table 1). The reduced vegetation cover in the palm circle, due to regular weeding and raking (see Methods section), may have further constrained microbial biomass compared to the inter-row (Table 1), and led to lower gross $\mathrm{N}$ mineralization rates (Table 1). The microbial biomass in the palm circle remained low despite the high base saturation (Table 2), resulting from liming and $\mathrm{K}$ fertilization. Therefore, management practices should aim at increasing the input of organic matter to the soil in order to enhance microbial biomass and promote the soil $\mathrm{N}$ cycle.

The fast turnover times of mineral $\mathrm{N}$ and microbial $\mathrm{N}$ pools in this large-scale plantation indicated a highly dynamic cycling of $\mathrm{N}$ in the soil. In the frond-stacked area, microbial immobilization was the main consumption process of produced mineral $\mathrm{N}$ (Table 1), which was mirrored by a large $\mathrm{N}$ demand by a large microbial biomass 
and available organic C (Table 2; Hart et al. 1994a). This efficient mechanism of $\mathrm{N}$ retention could result in low gaseous and leaching losses of $\mathrm{N}$ from the frond-stacked area. In contrast, in the inter-row and palm circle nitrification became a more important process relative to $\mathrm{NH}_{4}{ }^{+}$immobilization. Chronic $\mathrm{N}$ fertilization promotes gross nitrification despite a reduction in microbial biomass (Baldos et al. 2015, Corre et al. 2010, Zhang et al. 2013). It is important to note that our measured soil-N-cycling rates represented soil conditions beyond the pulse effects of $\mathrm{N}$-fertilizer application, which generally caused elevated mineral $\mathrm{N}$ concentrations for only six weeks following fertilization (Hassler et al. 2017). Thus, the low soil-N-cycling rates in the palm circle (Table 1), where fertilizers were applied, suggest that excess $\mathrm{N}$ from pulse $\mathrm{N}$-fertilizer application may move down in the soil profile and may be potentially retained in the subsoil by the anion exchange capacity inherent to Acrisol soils (Lehmann et al. 2004) or eventually lost through leaching (Tung et al. 2009) and in gaseous form (Fig. 3, Hassler et al. 2017). The low gross $\mathrm{N}$ mineralization in the palm circle signified the inherently low $\mathrm{N}$-supplying capacity of the soil in this intensively managed area, and illustrated its dependence on chemical fertilizer inputs to maintain palm growth.

The larger gross rates of mineral $\mathrm{N}$ production in frond-stacked area compared to the smallholder oil palm plantations (Fig. 3) attested the recovery of the soil's Nsupplying capacity when organic matter is restored. On the contrary, the lower total N and microbial $\mathrm{N}$ contents in the palm circle and inter-rows of the large-scale plantation compared to smallholder plantations (Fig. 3) suggest that the highly intensive management practices in the large-scale plantation, particularly in these two zones, had a larger impact on reducing organic matter than the lower intensity of management in the smallholder plantations. The larger gross nitrification in the frond-stacked area compared to forest (Fig. 3) could be the result of increased abundance of nitrifiers in the soils from increased $\mathrm{N}$ mineralization of nutrient-rich leaf litter. This is supported by a study in the same area that recorded higher abundance of nitrification-related taxa in 
oil palm plantations compared to forest (Berkelmann et al. 2018). Furthermore, the decreased DNRA (relative to nitrification and $\mathrm{NO}_{3}{ }^{-}$immobilization) in the frond-stacked area compared to forest (Fig. 3) suggests a functional shift, which may be driven in part by changes in microbial community composition. In the same forest and smallholder oil palm sites, the bacterial community in the soil shifted from proteobacterial groups in the forest to Acidobacteria in oil palm plantations with higher diversity of the soil prokaryotic communities in oil palm than in forest (Schneider et al. 2015). The larger microbial $\mathrm{C}$ and $\mathrm{C}: \mathrm{N}$ ratio in the frond-stacked area (Table 1) compared to the forests (microbial C of $514 \pm 48 \mathrm{mg} \mathrm{C} \mathrm{kg}^{-1}$ and microbial C:N ratio of 7.2 \pm 0.3 ; Allen et al. 2015) may explain the larger $\mathrm{N}$ immobilization rates in the frond-stacked area compared to the forest (Fig. 3), as immobilization can be fueled by increased availability of organic matter (Table 2; Booth et al. 2005, Hart et al. 1994a). Altogether, these findings indicated that mulching with senesced fronds in frond-stacked areas of oil palm plantations can be an effective practice to restore soil-N-cycling rates and microbial biomass size to levels comparable with, or even higher than, the forest. 


\subsection{Conclusion}

At this early stage of this management experiment in a large-scale oil palm plantation, our study revealed that nutrient cycling can be sustained by retaining the litter in the plantation. For this inherently nutrient-poor Acrisol soil, this can reduce dependency on large fertilizer and liming inputs. Management practices should aim at increasing the return of litter and other organic by-products of palm oil production to the soil in order to promote microbial biomass and nutrient recycling. Supporting soil-N-cycling rates with measurements of functional diversity of microbial community and $\mathrm{N}$ losses (e.g. gaseous emissions and leaching) would be an important next step to quantify $\mathrm{N}$ retention efficiency, yield response efficiency, and to extend our understanding on how to manage better the functional diversity of the soil microbiome to sustain fertility. This management experiment warrants further investigation on whether long-term reduction in management intensity can minimize the environmental footprint while maintaining productivity and profit. Our findings on the benefits of using senesced fronds for soil mulching can be used as one field criterion for RSPO certification of soil nutrient management. Investigations on other nutrient-rich by-products of oil palm processing, e.g. empty fruit bunches, are also needed to explore other measures for decreasing dependency on chemical fertilizers while restoring soil nutrient cycling. 


\section{Acknowledgements}

This research is part of the project A05 of the Collaborative Research Center 990 EFForTS project (Ecological and Socioeconomic Functions of Tropical Lowland Rainforest Transformation Systems), funded by the Deutsche Forschungsgemeinschaft (DFG, CRC 990/2). We thank PT Perkebunan Nusantara VI (PTPN VI) for allowing us to conduct our research in their plantation. We are especially thankful to our Indonesian field and laboratory assistants, Happy Chandra, Fajar Sidik and Sofyan Raden, as well as Kevin Darras and the project Z01 for managing the field implementation of this experiment. We acknowledge Christian Stiegler and the project A03 for the climate data. We also acknowledge Reinhard Langel and Lars Szwec from the Centre for Stable Isotope Research and Analysis (Goettingen University). We thank Andrea Bauer, Martina Knaust, and Kerstin Langs for their assistance in the laboratory analysis. This study was conducted under the research permit 351/SIP/FRP/E5/Dit.KI/X/2016.

\section{Declaration of author contribution}

EV and MDC conceptualized the study design, methodologies and laboratory analyses. AT facilitated field access, logistical support, collaborator agreements and material exports. GF conducted the field works and data analysis, and wrote the first draft of the manuscript. MDC and EV revised and commented on the previous versions, and all co-authors suggested and approved the final manuscript 


\subsection{Supplementary material}

Figure S1: Plots with conventional fertilization-herbicide treatment (a), and with reduced fertilization-mechanical weeding (b), taken in February 2017 four months after the latest treatment application, in a large-scale oil palm plantation in Jambi province, Indonesia.

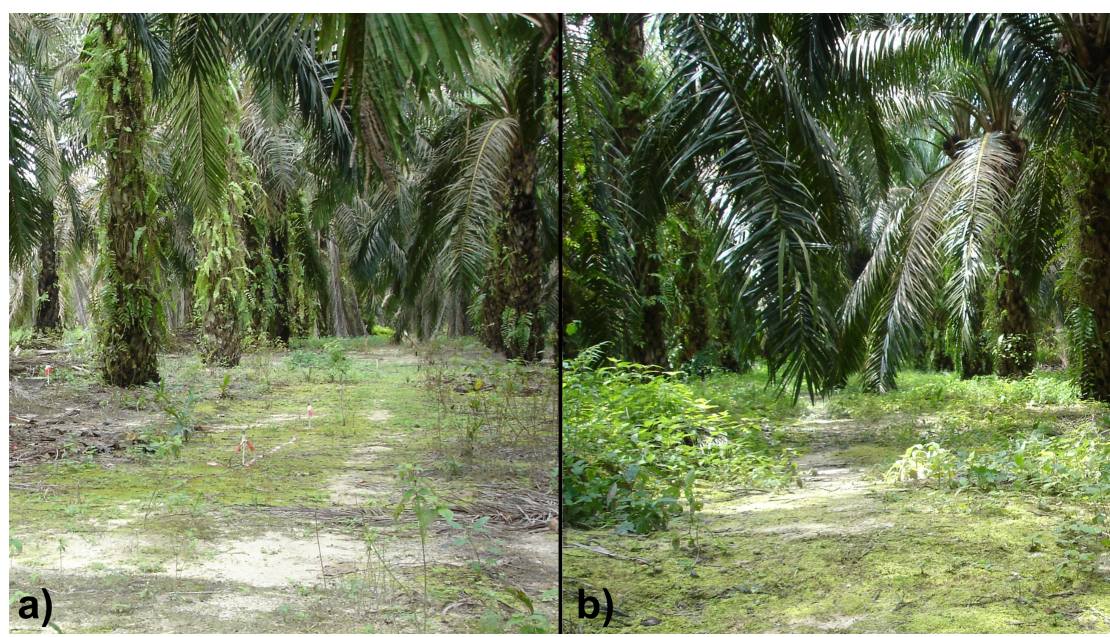

Figure S2: Intact soil cores incubated in the field for measurements of gross rates of soil-N cycling at each management zone: frond-stacked area (a), inter-row (b), and palm circle (c).

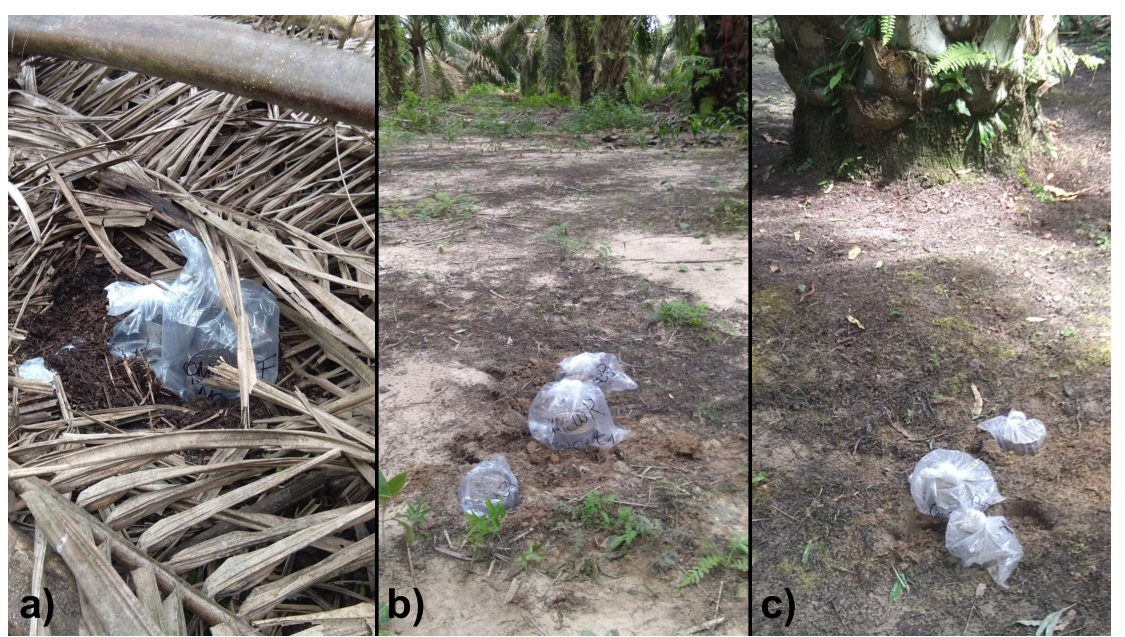




\section{References}

- Abu Bakar R, Darus SZ, Kulaseharan S, Jamaluddin N (2011) Effects of ten year application of empty fruit bunches in an oil palm plantation on soil chemical properties. Nutrient Cycling in Agroecosystems 89(3):341-349.

doi:10.1007/s10705-010-9398-9

- Allen K, Corre MD, Kurniawan S, Utami SR, Veldkamp E (2016) Spatial variability surpasses land-use change effects on soil biochemical properties of converted lowland landscapes in Sumatra, Indonesia. Geoderma 284: 42-50.

doi:10.1016/j.geoderma.2016.08.010

- Allen K, Corre MD, Tjoa A, Veldkamp E (2015) Soil nitrogen-cycling responses to conversion of lowland forests to oil palm and rubber plantations in Sumatra, Indonesia. PloS One 10(7):e0133325. doi:10.1371/journal.pone.0133325

- Aljuboori AHR (2013) Oil palm biomass residue in Malaysia: availability and sustainability. International Journal of Biomass and Renewables 1:13-8

- Ashton-Butt A, Aryawan AAK, Hood ASC, Naim M, Purnomo D, Suhardi, Wahyuningsih R, Willcock S, Poppy GM, Caliman J-P, Turner EC, Foster WA, Peh KSH, Snaddon JL (2018) Understory vegetation in oil palm plantations benefits soil biodiversity and decomposition rates. Frontiers in Forests and Global Change 1:19. doi:10.3389/ffgc.2018.00010

- Baldos AP, Corre MD, Veldkamp E (2015) Response of N cycling to nutrient inputs in forest soils across a 1000-3000 m elevation gradient in the Ecuadorian Andes.

Ecology 96(3):749-761. doi:10.1890/14-0295.1

- Berkelmann D, Schneider D, Engelhaupt M, Heinemann M, Christel S, Wijayanti M, Meryandini A, Daniel R (2018) How rainforest conversion to agricultural systems in Sumatra (Indonesia) affects active soil bacterial communities. Frontiers in Microbiology 9:2381. doi:10.3389/fmicb.2018.02381

- Booth MS, Stark JM, Rastetter E (2005) Controls on nitrogen cycling in terrestrial ecosystems: a synthetic analysis of literature data. Ecological Monographs 75(2):139-157. doi:10.1890/04-0988

- Brookes PC, Landman A, Pruden G, Jenkinson DS (1985) Chloroform fumigation and the release of soil nitrogen: a rapid direct extraction method to measure microbial biomass nitrogen in soil. Soil Biology and Biochemistry 17(6):837-842.

doi:10.1016/0038-0717(85)90144-0

- Carron MP, Auriac Q, Snoeck D, Villenave C, Blanchart E, Ribeyre F, Marichal R, Darminto M, Caliman JP (2015) Spatial heterogeneity of soil quality around mature oil 
palms receiving mineral fertilization. European Journal of Soil Biology 66:24-31. doi:10.1016/j.ejsobi.2014.11.005

- Carter C, Finley W, Fry J, Jackson D, Willis L (2007) Palm oil markets and future supply. European Journal of Lipid Science and Technology 109: 307-314. doi:10.1002/ejlt.200600256

- Clough Y, Krishna VV, Corre MD, Darras K, Denmead LH, Meijide A, Moser S, Musshoff O, Steinebach S, Veldkamp E, Allen K, Barnes AD, Breidenbach N, Brose U, Buchori D, Daniel R, Finkeldey R, Harahap I, Hertel D, Holtkamp AM, Hörandl E, Irawan B, Jaya INS, Jochum M, Klarner B, Knohl A, Kotowska MM, Krashevska V, Kreft H, Kurniawan S, Leuschner C, Maraun M, Melati DN, Opfermann N, Pérez-Cruzado C, Prabowo WE, Rembold K, Rizali A, Rubiana R, Schneider D, Tjitrosoedirdjo SS, Tjoa A, Tscharntke T, Scheu S (2016) Land-use choices follow profitability at the expense of ecological functions in Indonesian smallholder landscapes. Nature Communications 7:13137. doi:10.1038/ncomms13137 - Comte I, Colin F, Whalen JK, Grünberger O, Caliman J-P (2012) Agricultural practices in oil palm plantations and their impact on hydrological changes, nutrient fluxes and water quality in Indonesia. Advances in Agronomy 116: 71-124. doi:10.1016/B978-0-12-394277-7.00003-8

- Cookson WR, Marschner P, Clark IM, Milton N, Smirk MN, Murphy DV, Osman M, Stockdale EA, Hirsch PR (2006) The influence of season, agricultural management, and soil properties on gross nitrogen transformations. Australian Journal of Soil Research 44(4):453-465.doi:10.1071/SR05042

- Corley RHV, Tinker PB (2016) The oil palm, 5th ed. John Wiley \& Sons, Ltd, Hoboken, NJ

- Corre MD, Lamersdorf NP (2004) Reversal of nitrogen saturation after long-term deposition reduction: impact on soil nitrogen cycling. Ecology 85(11):3090-3104. doi:10.1890/03-0423

- Corre, MD, Dechert G, Veldkamp E (2006) Soil nitrogen cycling following montane forest conversion in Central Sulawesi, Indonesia. Soil Science Society of America Journal 70:359-366. doi:10.2136/sssaj2005.0061

- Corre MD, Sueta JP, Veldkamp E (2014) Nitrogen-oxide emissions from tropical forest soils exposed to elevated nitrogen input strongly interact with rainfall quantity and seasonality. Biogeochemistry 118:103-120. doi:10.1007/s10533-013-9908-3

- Corre MD, Veldkamp E, Arnold J, Wright SJ (2010) Impact of elevated N input on soil $\mathrm{N}$ cycling and losses in old-growth lowland and montane forests in Panama. Ecology 91(6):1715-1729. doi:10.1890/09-0274.1 
- Craine JM, Brookshire ENJ, Cramer MD, Hasselquist NJ, Koba K, Marin-Spiotta E, Wang L (2015) Ecological interpretations of nitrogen isotope ratios of terrestrial plants and soils. Plant and Soil 396:1-26. doi:10.1007/s11104-015-2542-1

- Darras KFA, Corre MD, Formaglio G, Tjoa A, Potapov A, Brambach F, Sibhatu KT, Grass I, Rubiano AA, Buchori D, Drescher J, Fardiansah R, Hölscher D, Irawan B, Kneib T, Krashevska V, Krause A, Kreft H, Li K, Maraun M, Polle A, Ryadin AR, Rembold K, Stiegler C, Scheu S, Tarigan S, Valdés-Uribe A, Yadi S, Tscharntke T, Veldkamp E (2019) Reducing fertilizer and avoiding herbicides in oil palm plantations - ecological and economic valuations. Frontiers in Forests and Global Change 2. doi:10.3389/ffgc.2019.00065

- Davidson EA, Hart SC, Shanks CA, Firestone MK (1991) Measuring gross nitrogen mineralization, and nitrification by $15 \mathrm{~N}$ isotopic pool dilution in intact soil cores. Journal of Soil Science 42:335-349. doi:10.1111/j.1365-2389.1991.tb00413.x

- Directorate General of Estate Crop (2017) Tree crop estate statistics of Indonesia 2015 - 2017: palm oil

- Dislich C, Keyel AC, Salecker J, Kisel Y, Meyer KM, Auliya M, Barnes AD, Corre MD, Darras K, Faust H, Hess B, Klasen S, Knohl A, Kreft H, Meijide A, Nurdiansyah F, Otten F, Pe'er G, Steinebach S, Tarigan S, Tölle MH, Tscharntke T, Wiegand K (2017) A review of the ecosystem functions in oil palm plantations, using forests as a reference system. Biological Reviews of the Cambridge Philosophical Society 92:1539-1569. doi:10.1111/brv.12295

- FAO (2017) Food and Agricolture Organization, FAOSTAT. http:/ / faostat.fao.org/site/339/default.aspx. Accessed 23 Aug 2019

- Frazão LA, Paustian K, Cerri CEP, Cerri CC (2014) Soil carbon stocks under oil palm plantations in Bahia State, Brazil. Biomass and Bioenergy 62:1-7. doi:10.1016/j.biombioe.2014.01.031

- Hall SJ, Matson PA (1999) Nitrogen oxide emissions after nitrogen additions in tropical forests. Nature 400:152. doi:10.1038/22094

- Haron K, Brookes PC, Anderson JM, Zakaria ZZ (1998) Microbial biomass and soil organic matter dynamics in oil palm (Elaeis Guineensis Jacq.) plantations, West Malaysia. Soil Biology and Biochemistry 30(5):547-552.

doi:10.1016/S0038-0717(97)00217-4

- Harris D, Horwáth WR, van Kessel C (2001) Acid fumigation of soils to remove carbonates prior to total organic carbon or carbon-13 isotopic analysis. Soil Science Society of America Journal 65:1853-1856. doi:10.2136/sssaj2001.1853 
- Hart SC, Nason GE, Myrold DD, Perry DA (1994a) Dynamics of gross nitrogen transformations in an old-growth forest: the carbon connection. Ecology 75(4):880-891. doi:10.2307/1939413

- Hart SC, Stark JM, Davidson EA, Firestone MK (1994b) Nitrogen mineralization, immobilization, and nitrification. Methods of Soil Analysis. Part 2. Soil Science society of America Book Series. Microbiological and Biochemical Properties, Madison, WI, USA

- Hassler E, Corre MD, Kurniawan S, Veldkamp E (2017) Soil nitrogen oxide fluxes from lowland forests converted to smallholder rubber and oil palm plantations in Sumatra, Indonesia. Biogeosciences 14:2781-2798. doi:10.5194/bg-14-2781-2017 - Koehler B, Corre MD, Veldkamp E, Wullaert H, Wright SJ (2009) Immediate and long-term nitrogen oxide emissions from tropical forest soils exposed to elevated nitrogen input. Global Change Biology 15(8):2049-2066. doi:10.1111/j.1365-2486.2008.01826.x

- Kotowska MM, Leuschner C, Triadiati T, Hertel D (2016) Conversion of tropical lowland forest reduces nutrient return through litterfall, and alters nutrient use efficiency and seasonality of net primary production. Oecologia 180:601-618. doi:10.1007/s00442-015-3481-5

- Kotowska MM, Leuschner C, Triadiati T, Meriem S, Hertel D (2015) Quantifying above- and belowground biomass carbon loss with forest conversion in tropical lowlands of Sumatra (Indonesia). Global Change Biology 21: 3620-3634. doi:10.1111/gcb.12979

- Kurniawan S, Corre MD, Matson AL, Schulte-Bisping H, Utami SR, van Straaten O, Veldkamp E (2018) Conversion of tropical forests to smallholder rubber and oil palm plantations impacts nutrient leaching losses and nutrient retention efficiency in highly weathered soils. Biogeosciences 15:5131-5154. doi:10.5194/bg-15-5131-2018 - Lang M, Li P, Han X, Qiao Y, Miao S (2016) Gross nitrogen transformations in black soil under different land uses and management systems. Biology and Fertility of Soils 52: 233-241. doi:10.1007/s00374-015-1070-8

- Lee JSH, Abood S, Ghazoul J, Barus B, Obidzinski K, Koh LP (2014) Environmental impacts of large-scale oil palm enterprises exceed that of smallholdings in Indonesia. Conservation Letters 7(1):25-33. doi:10.1111/conl.12039

- Leff JW, Wieder WR, Taylor PG, Townsend AR, Nemergut DR, Grandy AS, Cleveland CC (2012) Experimental litterfall manipulation drives large and rapid changes in soil carbon cycling in a wet tropical forest. Global Change Biology 18:2969-2979. doi:10.1111/j.1365-2486.2012.02749.x 
- Lehmann J, Lilienfein J, Rebel K, Carmo Lima S, Wilcke W (2004) Subsoil retention of organic and inorganic nitrogen in a Brazilian savanna Oxisol. Soil Use and Management 20(2):163-172. doi:10.1111/j.1475-2743.2004.tb00352.x

- Li Y, Xu M, Sun OJ, Wangcheng C (2004) Effects of root and litter exclusion on soil $\mathrm{CO} 2$ efflux and microbial biomass in wet tropical forests. Soil Biology and Biochemistry 36:2111-2114. doi:10.1016/j.soilbio.2004.06.003

- Mendham DS, Sankaran KV, O'Connell AM, Grove TS (2002) Eucalyptus Globulus harvest residue management effects on soil carbon and microbial biomass at 1 and 5 years after plantation establishment. Soil Biology and Biochemistry 34:1903-1912 doi:10.1016/S0038-0717(02)00205-5

- Ministry of Agriculture of Indonesia (2016) Guidelines on oil palm replanting. Regulation No: 18/Permentan/KB.330/5/2016

- Moradi A, Teh CBS, Goh KJ, Husni MHA, Ishak CF (2014) Decomposition and nutrient release temporal pattern of oil palm residues. Annals of Applied Biology 164:208-219. doi:10.1111/aab.12094

- Moradi A, Teh Boon Sung C, Goh KJ, Husni Mohd Hanif A, Fauziah Ishak C (2015) Effect of four soil and water conservation practices on soil physical processes in a non-terraced oil palm plantation. Soil and Tillage Research 145: 62-71.

doi:10.1016/j.still.2014.08.005

- Müller AK, Matson AL, Corre MD, Veldkamp E (2015) Soil N2O fluxes along an elevation gradient of tropical montane forests under experimental nitrogen and phosphorus addition. Frontiers in Earth Science 3:66. doi:10.3389/feart.2015.00066 - Nelson PN, Banabas M, Scotter DR, Webb MJ (2006) Using soil water depletion to measure spatial distribution of root activity in oil palm (Elaeis Guineensis Jacq.) plantations. Plant and Soil 286:109-121. doi:10.1007/s11104-006-9030-6

- Omoti U, Ataga DO, Isenmila AE (1983) Leaching losses of nutrients in oil palm plantations determined by tension lysimeters. Plant and Soil 73: 365-376.

doi:10.1007/BF02184313

- Pahan I (2010) Complete guide to oil palm, 8th edition. Penebar Swadaya, Jakarta, Indonesia

- R Core Team (2019) R: A language and environment for statistical computing. Foundation for Statistical Computing, Vienna, Austria

- Rahman N, Neergaard A de, Magid J, van de Ven GWJ, Giller KE, Bruun TB (2018) Changes in soil organic carbon stocks after conversion from forest to oil palm plantations in Malaysian Borneo. Environ. Res. Lett. 13(10): 105001. doi:10.1088/1748-9326/aade0f 
- RSPO (2018) Principles and criteria. For the production of sustainable palm Oil

- Sanchez PA, Logan TJ (1992) Myths and science about the chemistry and fertility of soils in the tropics. Soil Science Society of America and American Society of Agronomy 29. doi:10.2136/sssaspecpub29.c3

- Sayer EJ, Powers JS, Tanner EVJ (2007) Increased litterfall in tropical forests boosts the transfer of soil CO2 to the atmosphere. PloS One 2(12):e1299.

doi:10.1371/journal.pone.0001299

- Schneider D, Engelhaupt M, Allen K, Kurniawan S, Krashevska V, Heinemann M, Nacke H, Wijayanti M, Meryandini A, Corre MD, Scheu S, Daniel R (2015) Impact of lowland rainforest transformation on diversity and composition of soil prokaryotic communities in Sumatra (Indonesia). Frontiers in Microbiology 6:1339. doi:10.3389/fmicb.2015.01339

- Schroth G, Rodrigues MRL, D'Angelo SA (2000) Spatial patterns of nitrogen mineralization, fertilizer distribution and roots explain nitrate leaching from mature Amazonian oil palm plantation. Soil Use and Management 16:222-229. doi:10.1111/j.1475-2743.2000.tb00197.x

- Silver WL, Herman DJ, Firestone MK (2001) Dissimilatory nitrate reduction to ammonium in upland tropical forest soils. Ecology 82(9):2410-2416. doi:10.1890/0012-9658(2001)082[2410:DNRTAI]2.0.CO;2

- Silver WL, Thompson AW, Reich A, Ewel JJ, Firestone MK (2005) Nitrogen cycling in tropical plantation forests: potential controls on nitrogen retention. Ecological Applications 15(5):1604-1614. doi:10.1890/04-1322

- Singh P, Ghoshal N (2010) Variation in total biological productivity and soil microbial biomass in rainfed agroecosystems: impact of application of herbicide and soil amendments. Agriculture, Ecosystems \& Environment 137(3):241-250. doi:10.1016/j.agee.2010.02.009

- Tao H-H, Slade EM, Willis KJ, Caliman J-P, Snaddon JL (2016) Effects of soil management practices on soil fauna feeding activity in an Indonesian oil palm plantation. Agriculture, Ecosystems \& Environment 218:133-140.

doi:10.1016/j.agee.2015.11.012

- Tung PGA, Yusoff MK, Majid NM, Joo GK, Huang GH (2009) Effect of N and K fertilizers on nutrient leaching and groundwater quality under mature oil palm in Sabah during the monsoon period. American Journal of Applied Sciences 6(10):1788-1799. doi:10.3844/ajassp.2009.1788.1799

- Zhang J, Zhu T, Meng T, Zhang Y, Yang J, Yang W, Müller C, Cai Z (2013) Agricultural land use affects nitrate production and conservation in humid 
subtropical soils in China. Soil Biology and Biochemistry 62:107-114.

doi:10.1016/j.soilbio.2013.03.006 


\section{Chapter 3}

\section{Biological asymbiotic nitrogen fixation in soil and litter in a large-scale oil palm plantation}

Greta Formaglio, Edzo Veldkamp, Aiyen Tjoa, Marife D. Corre 


\section{Abstract}

Asymbiotic $\mathrm{N}_{2}$ fixation can be an important source of $\mathrm{N}$ to crops but little is known about this process in tropical agricultural systems, like oil palm plantations. The intensive management practices typical of large-scale oil palm plantations are likely to affect asymbiotic $\mathrm{N}_{2}$ fixation. We assessed the effect of management practices on asymbiotic $\mathrm{N}_{2}$ fixation in soil and litter and we investigated the role of nutrients in regulating this process. We compared soil asymbiotic $\mathrm{N}_{2}$ fixation rates three zones in the plantation, characterized by different management: the fertilized and weeded palm circle, the weeded inter-row and the mulched frond-stacked area. Also we established a management experiment with four treatment combinations: conventional fertilization ( $260 \mathrm{~N}, 50 \mathrm{P}, 220 \mathrm{~K} \mathrm{~kg} \mathrm{ha}^{-1} \mathrm{yr}^{-1}$ ) with herbicide spraying (2.25 $\mathrm{L}_{\text {glyphosate }} \mathrm{ha}^{-1} \mathrm{yr}^{-1}$ ), conventional fertilization with mechanical weeding, reduced fertilization $(136 \mathrm{~N}, 17 \mathrm{P}$, $187 \mathrm{~K} \mathrm{~kg} \mathrm{ha}^{-1} \mathrm{yr}^{-1}$ ) with herbicide spraying, and reduced fertilization with mechanical weeding. We measured asymbiotic $\mathrm{N}_{2}$ fixation in the litter (the frond pile) and in the top-5-cm soil once a month for one year, using the acetylene reduction assay. Soil and litter properties were also measured. The results showed no clear trend among experimental treatments but clear differences $(\mathrm{p}<0.01)$ among management zones with higher rates in the palm circle and lower rates in the frond-stacked area, and inter-row in between. The soil $\mathrm{N}$ content and $\mathrm{pH}$ were the main factors determining these differences. Asymbiotic $\mathrm{N}_{2}$ fixation in litter was higher than in the soil, but, given the limited amount of litter in the plantation, the contribution to the plantation $\mathrm{N}$ budget was limited. 


\subsection{Introduction}

The main natural pathway through which $\mathrm{N}$ enters the ecosystem in a plant-available form is biological $\mathrm{N}_{2}$ fixation (Galloway et al. 1995). This is carried out by specialized microorganisms, known as diazotrophic bacteria, which can occur as symbionts of leguminous plants or free-living in soil and litter. Asymbiotic $\mathrm{N}_{2}$ fixation, carried out by free-living diazotrophic bacteria, is nearly ubiquitous in terrestrial ecosystems, and can represent the main source of fixed $\mathrm{N}$, especially in ecosystems where symbiotic N-fixing plants are not abundant (Cleveland et al. 1999, Reed et al. 2011). While tropical forests have the highest $\mathrm{N}_{2}$ fixation rates among terrestrial ecosystems (Cleveland et al. 1999), asymbiotic $\mathrm{N}_{2}$ fixation in tropical agricultural ecosystems is highly uncertain. Oil palm is one of the most important tree cash crop, being the world's leading vegetable oil (Carter et al. 2007), with a rapid expansion in the last two decades from 6 to 20 Million ha between 1990 to 2015 , accounting for $12 \%$ of the total permanent cropland (FAO 2018). This expansion has been especially remarkable in Indonesia, where the planted area covers approximately 9 Million ha (FAO 2018), distributed mainly in the islands of Sumatra and Kalimantan (Directorate General of Estate Crop 2017). The high productivity of oil palm plantations is dependent on chemical fertilizer input. Compared to tropical forests, oil palm plantations have lower natural input of $\mathrm{N}$ into the soil, because of lower return of $\mathrm{N}$ thought litterfall, lower $\mathrm{N}$ mineralization from organic matter and in general reduced nutrient cycling functions, from vertebrates, to invertebrates, to N-fixing bacteria (Allen et al. 2015, Barnes et al. 2017, Kotowska et al. 2016, Schneider et al. 2015). Also, oil palm plantations have lower plant diversity than forests, including leguminous species, which are absent in mature oil palm plantations (Corley and Tinker 2016, Rembold et al. 2017), with consequently minimal symbiotic $\mathrm{N}_{2}$ fixation. Therefore, our study aimed to measure asymbiotic $\mathrm{N}_{2}$ fixation in an oil palm plantation to evaluate the importance of this pathway as a natural source of $\mathrm{N}$ 
to the soil, and its potential to decrease the dependency on chemical fertilizer input. We investigated asymbiotic $\mathrm{N}_{2}$ fixation in soil and in litter, which is represented by senesced fronds piled up on the soil, since these nutrient-rich substrates (Kotowska et al. 2016) have not been investigated on their N-fixing capacity; we worked in Sumatra, where oil palm plantations are one of the dominant agricultural ecosystem.

Large-scale oil palm plantations are typically intensively managed, with high rates of fertilization and herbicide application for weed control. These management practices are likely to affect asymbiotic $\mathrm{N}_{2}$ fixation, as they alter the nutrient and organic matter input to the soil. Fertilization with $\mathrm{N}$ can suppress asymbiotic $\mathrm{N}_{2}$ fixation (Barron et al. 2009, Matson et al. 2015), as the energy costly $\mathrm{N}_{2}$ fixation by free-living diazotrophic bacteria no longer provides a competitive advantage (Hedin et al. 2009). Nevertheless, in some exceptional case, where $\mathrm{N}$ is strongly limiting, there can be no inhibitory effect of $\mathrm{N}$ fertilization, as the quantity added does not exceed the ecosystem demand for N (Reed et al. 2007). On the other hand, intensive weeding practices can influence asymbiotic $\mathrm{N}_{2}$ fixation by altering the biomass and composition of the understory vegetation in oil palm plantations (Darras et al. 2019, Luke et al. 2019) which, in turn, affect the organic matter input as well as water infiltration and retention in the soil. A positive relationship between asymbiotic $\mathrm{N}_{2}$ fixation and soil $\mathrm{C}$ concentrations have been reported (Hofmockel and Schlesinger 2007, van Langenhove et al. 2019), which indicates the role of $C$ availability as energy source for the free-living $\mathrm{N}$ fixing bacteria. Moreover, high moisture content can stimulate asymbiotic $\mathrm{N}_{2}$ fixation in soil and litter (Cusack et al. 2009, Matson et al. 2015) by reducing oxygen concentration that favors the activity of oxygen-sensitive nitrogenase enzyme (Hofmockel and Schlesinger 2007). Based on these, we expect that a reduction of fertilization and weeding intensity could positively impact asymbiotic $\mathrm{N}_{2}$ fixation directly, through a reduction of the inhibitory effect of $\mathrm{N}$ application, and indirectly, by promoting understory vegetation with the associated positive effects. 
Finally, intensive management practices of large-scale oil palm plantations create a very defined spatial structure with three distinct management zones: (1) the palm circle, an area around the palm's trunks where fertilizers are applied and regularly weeded; (2) the inter-row, an area between palm rows that is not fertilized but weeded; and (3) the frond-stacked area, where the pruned fronds, which are cut regularly to facilitate harvesting, are used as mulch on the soil at every second inter-rows. The different management of these zones allow the investigation of the effect of management practices (i.e. fertilization, weeding, and mulching) on asymbiotic $\mathrm{N}_{2}$ fixation. These three management zones differ in soil physical and chemical properties (Haron et al. 1998, Rahman et al. 2018, Rüegg et al. 2019) as well as internal soil-N cycling rates (Chapter 2), and thus provide a platform for evaluating the roles of nutrient availability on regulating soil asymbiotic $\mathrm{N}_{2}$ fixation.

This study aimed to address the knowledge gap on one of the natural pathways of $\mathrm{N}$ input in oil palm plantations. We aimed to quantify asymbiotic $\mathrm{N}_{2}$ fixation, to assess the relationships with nutrient availability and to evaluate the impact of agricultural management practices. The hypothesis of this study are that (1) the different nutrient availability of the management zones will result in differences in soil asymbiotic $\mathrm{N}_{2}$ fixation rates and that (2) reduction of management intensity (i.e. reduced intensity of fertilization and weeding) will stimulate asymbiotic $\mathrm{N}_{2}$ fixation in soil and litter because of reduction of $\mathrm{N}$ inputs and increase of understory vegetation

\subsection{Materials and Methods}

\subsubsection{Study site and experimental design}

This study was conducted in a large-scale oil palm plantation in Jambi province, Indonesia ( $1^{\circ} 43^{\prime} 8^{\prime \prime} \mathrm{S}, 103^{\circ} 23^{\prime} 53^{\prime \prime}$ E, elevation $73 \mathrm{~m}$ above sea level) with a highly weathered Acrisol (Allen et al. 2015). The climate in the area has mean annual tem- 
perature of $26.7 \pm 1.0^{\circ} \mathrm{C}$ and mean annual precipitation of $2235 \pm 385 \mathrm{~mm}$ (1991-2011; climate station at the Jambi Sultan Thana airport of the Meteorological, Climatological and Geophysical Agency). The climatic data measured during our study period (March 2017-February 2018) showed a mean daily air temperature of $26.3^{\circ} \mathrm{C}$ and annual precipitation of $2772 \mathrm{~mm}$. Total nutrient deposition through rainfall, measured in 2013, was $12.9 \mathrm{~kg} \mathrm{~N}, 0.4 \mathrm{~kg} \mathrm{P,} 5.5 \mathrm{~kg} \mathrm{~K} \mathrm{ha}^{-1} \mathrm{yr}^{-1}$ (Kurniawan et al. 2018). This largescale (2025 ha) oil palm plantation was established between 1998 and 2002, such that the palms were 16-20 years old during the study period. The palms were planted in rows at $8 \mathrm{~m}$ distance between rows and between palms in a row, with average planting density of 142 palms ha $^{-1}$.

We established a management experiment in this oil palm plantation, starting in November 2016, with a $2 \times 2$ full-factorial treatments on fertilization rates (i.e. conventional high rates versus reduced rates based on harvest export) and weed control (i.e. herbicide versus mechanical weeding), resulting in four treatments combinations. These treatment combinations were assigned randomly to each of the four plots (50 m $\mathrm{x} 50 \mathrm{~m}$ each) within each of the four block replicates. The minimum distance between blocks was $200 \mathrm{~m}$ and between plots within a block was $70 \mathrm{~m}$. The conventional fertilization rates, commonly used by large-scale plantations in Jambi province, were 260 $\mathrm{N}, 50 \mathrm{P}, 220 \mathrm{~K} \mathrm{~kg} \mathrm{ha}^{-1} \mathrm{yr}^{-1}$, and for the reduced fertilization rates were $130 \mathrm{~N}, 17 \mathrm{P}, 187$ $\mathrm{K} \mathrm{kg} \mathrm{ha}^{-1} \mathrm{yr}^{-1}$.

These reduced rates were determined to compensate for nutrients exported with the harvested fruit bunches at the studied plantation. The nutrient contents in the fruit bunches was determined as follows: 20 fruit bunches were sampled at the plantation mill, separately for fruits and stalks, and measured for total N, P, and K contents. Total $\mathrm{N}$ was analyzed from dried $\left(60^{\circ} \mathrm{C}\right)$, ground samples using a $\mathrm{CN}$ analyzer (Vario EL Cube, Elementar Analysis Systems GmbH, Hanau, Germany) and total $\mathrm{P}$ and $\mathrm{K}$ were determined from dried, ground samples by pressure digestion with 
concentrated $\mathrm{HNO}_{3}$ and analyzed using an inductively coupled plasma-atomic emission spectrometer (ICP-AES; iCAP 6300 Duo VIEW ICP Spectrometer, Thermo Fischer Scientific GmbH, Dreieich, Germany). The nutrient exports were calculated by upscaling the measured nutrient concentrations in fruits and stalks with the long-term yield record of the plantation.

Fertilizer sources were urea for $\mathrm{N}$, triple superphosphate for $\mathrm{P}$, and muriate of potash for K; application was done twice per year (in April and October) within a 2-m radius around the palm (palm circle). Lime (426 kg dolomite $\mathrm{ha}^{-1} \mathrm{yr}^{-1}$ ) and micronutrients (142 kg micro-mag ha ${ }^{-1} \mathrm{yr}^{-1}$ with $0.5 \% \mathrm{~B}_{2} \mathrm{O}_{3}, 0.5 \% \mathrm{CuO}, 0.25 \% \mathrm{Fe}_{2} \mathrm{O}_{3}, 0.15 \% \mathrm{ZnO}$, $0.1 \% \mathrm{MnO}$ and $18 \% \mathrm{MgO}$ ) were also applied together with the $\mathrm{N}, \mathrm{P}$ and $\mathrm{K}$ fertilizers, as normally practiced in large-scale oil palm plantations on acidic soils (Acrisol) in the region. As to the weed control treatments, the herbicide weeding used $1.5 \mathrm{~L}$ glyphosate haha ${ }^{-1} \mathrm{yr}^{-1}$, split in four applications per year and applied within the palm circles, and $0.75 \mathrm{~L}_{\text {glyphosate }} \mathrm{ha}^{-1} \mathrm{yr}^{-1}$, divided in two applications per year and applied on the inter-rows. Mechanical weeding was carried out using a weed whacker to weed out the aboveground understory vegetation within the palm circles and inter-row in the same annual frequency as that of the herbicides.

For soil biochemical characteristics and asymbiotic $\mathrm{N}_{2}$ fixation, we selected two subplots in each plot and sampled in the top-5-cm depth at the three distinct management zones: (1) within the fertilized palm circle, (2) in the inter-row without direct fertilization, and (3) in the frond-stacked area, which was every second inter-row, mulched with senesced frond (Fig. 1). For the frond litter characteristics and asymbiotic $\mathrm{N}_{2}$ fixation, samples were taken from stacked frond piles (Fig. 1) and measured separately for leaflets and rachis, as these parts differ in macronutrient concentrations (Moradi et al. 2014). In total, there were 96 intact soil cores and 48 frond litters for measurements of asymbiotic $\mathrm{N}_{2}$ fixation, water content, and mineral $\mathrm{N}$ (see sections 2.2 and 2.3) during each measurement period. 
Figure 1: Sampling design within a treatment plot in a large-scale oil palm plantation. Two subplots (in green) were selected: top 5-cm mineral soil was sampled in each management zone per subplot (blue crosses) and litter was sampled from the frond stack in one subplot (red cross).

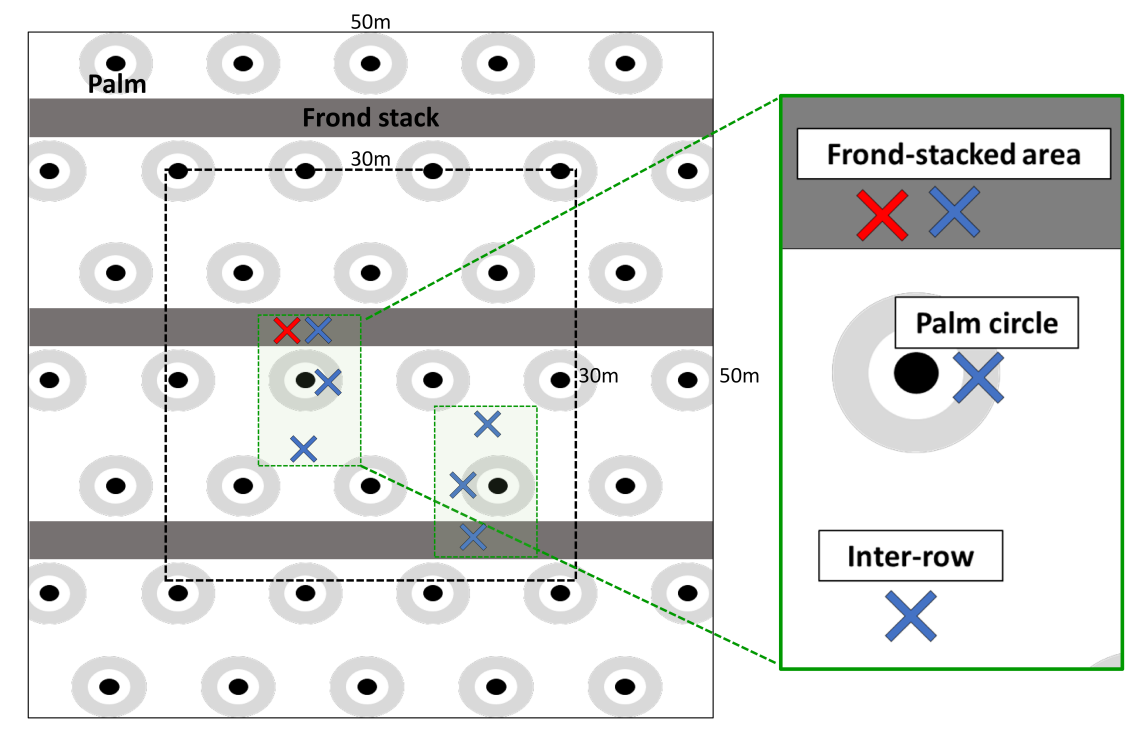

Soil characteristics (gross $\mathrm{N}$ mineralization, $\mathrm{pH}$, effective cation exchange capacity, base saturation) were measured one time in February 2018, 1.5 years after the start of the treatment and were reported in our early work (Chapter 2, Table S1). We investigated the relationship between asymbiotic $\mathrm{N}_{2}$ fixation and gross $\mathrm{N}$ mineralization, as this is a proxy for $\mathrm{N}$ availability in the soil. Litter parameters (moisture, $\mathrm{C}$ and nutrient contents) were measured four times in September, October, November 2017, and in February 2018.

\subsubsection{Measurements of asymbiotic nitrogen fixation}

We measured asymbiotic $\mathrm{N}_{2}$ fixation from intact soil cores and frond litter using the $\mathrm{C}_{2} \mathrm{H}_{2}$ reduction method (Hardy et al. 1968). Measurements were conducted in all plots and management zones generally once a month from March 2017 to March 2018, except in August 2017 for the soil and March, June, August and December 2017 for the frond litter, due to logistical problems. All plots within a block were measured on the same day. From every sampling location (Fig. 1), we took one intact soil core $\left(123 \mathrm{~cm}^{3}\right)$ in the 
top $5 \mathrm{~cm}$ and collected litter sample from the piled fronds, which was separated into leaflets and rachis. The samples were immediately placed in air-tight incubation glass jars (0.94 L volume), equipped with rubber septa for gas sampling of the headspace. In each jar, we exchanged $10 \%$ of the headspace air with $\mathrm{C}_{2} \mathrm{H}_{2}$, which was previously scrubbed in the laboratory by flowing through $98 \% \mathrm{H}_{2} \mathrm{SO}_{4}$ and $5 \mathrm{M} \mathrm{NaOH}$ (Hyman and Arp 1987). On each sampling day, one empty jar (without a soil core or litter) was also incubated the same as the samples to measure the background levels of ethylene $\left(\mathrm{C}_{2} \mathrm{H}_{4}\right)$. The jars were partially buried in the soil to incubate in situ for $24 \mathrm{~h}$. During this period, three gas samples $(20 \mathrm{~mL})$ were taken from each jar at 1, 3 and $24 \mathrm{~h}$ after $\mathrm{C}_{2} \mathrm{H}_{2}$ injection, using a gas-tight syringe, and injected into $12 \mathrm{~mL}$ pre-evacuated glass exetainers (Labco Limited, Lampeter, United Kingdom). These exetainers, which were tested to be leak proof from our previous work (Hassler et al. 2015), were transported to University of Göttingen, Germany, where they were analyzed for $\mathrm{C}_{2} \mathrm{H}_{4}$ concentrations using a gas chromatograph with a flame ionization detector and an autosampler (SRI 8610C, SRI Instruments Europe GmbH, Bad Honnef, Germany). We determined the $\mathrm{C}_{2} \mathrm{H}_{4}$ concentrations based on standard calibration curves $\left(\mathrm{R}^{2} \leq 0.99\right)$ established from various $\mathrm{C}_{2} \mathrm{H}_{4}$ concentrations, which we prepared by mixing $\mathrm{C}_{2} \mathrm{H}_{4}(99.5 \%$ purity, Westfalen AG, Münster Westfalen, Germany) with $\mathrm{N}_{2}$. Background levels of $\mathrm{C}_{2} \mathrm{H}_{4}$ from empty jars on each sampling day, ranging from 0.02 to $9.25 \mu \mathrm{L} \mathrm{L}^{-1}$ across the measurement period, were subtracted from the $\mathrm{C}_{2} \mathrm{H}_{4}$ concentrations of the incubated samples. Rates of $\mathrm{C}_{2} \mathrm{H}_{4}$ production were calculated as the slope of the regression line between $\mathrm{C}_{2} \mathrm{H}_{4}$ concentrations and incubation time; rates were considered equal to zero if the changes in $\mathrm{C}_{2} \mathrm{H}_{4}$ concentrations over the incubation period were lower than the minimum detectable concentration (MDC) on that sampling day, calculated as MDC = $3 \times$ standard deviation of the background $\mathrm{C}_{2} \mathrm{H}_{4}$ concentrations in the empty jars. At the end of the incubation period, the samples were brought to the field station (30 minutes from the study site) to determine the field-moist weights and the gravimetric moisture 
contents by taking subsamples for oven-drying at $105^{\circ} \mathrm{C}$ for $24 \mathrm{~h}$ for the soil and at $70^{\circ} \mathrm{C}$ for $48 \mathrm{~h}$ for the litter. We expressed the $\mathrm{C}_{2} \mathrm{H}_{4}$ production rates on dry mass soil or litter. To convert the measured rates to ground area basis, we measured the soil bulk density in the top $5 \mathrm{~cm}$ with the core method (Blake and Hartge 1986), and the litter amount by determining the dry mass of 10 frond samples (divided into leaflets and rachis) taken within $1 \mathrm{~m} \times 1 \mathrm{~m}$ section of the piled fronds in each plot. Annual rates were calculated for each plot and each management zone for the soil and frond litter by linear interpolation of monthly measured rates and sampling day intervals during the whole year.

As additional support of this $\mathrm{C}_{2} \mathrm{H}_{2}$ reduction method, we tested the soil and frond litter for endogenous $\mathrm{C}_{2} \mathrm{H}_{4}$ production, as suggested by Nohrstedt (1983). This test was performed by taking intact soil cores from the three management zones in two treatments, selected for their most contrasting management intensities (i.e. conventional fertilization-herbicide and reduced fertilization-mechanical weeding), with four replicate plots (total of 24 soil cores) as well as frond litters, and incubating them in glass jars with headspace concentrations of $0.05 \%$ of $\mathrm{C}_{2} \mathrm{H}_{2}$ (Nohrstedt 1983). We found no production of $\mathrm{C}_{2} \mathrm{H}_{4}$ during the 24-h incubation period. We also tested the soils for endogenous $\mathrm{C}_{2} \mathrm{H}_{4}$ consumption by incubating intact soil cores in glass jars with headspace concentrations of $0.001 \% \mathrm{C}_{2} \mathrm{H}_{4}$ for $24 \mathrm{~h}$ (Keuter et al. 2014), and no $\mathrm{C}_{2} \mathrm{H}_{4}$ consumption was detected.

\subsubsection{Determination of conversion factor of ethylene production to nitrogen fixation and controlling factors of asymbiotic nitrogen fixation}

We determined the conversion factor of $\mathrm{C}_{2} \mathrm{H}_{4}$ production to $\mathrm{N}_{2}$ fixation by calibrating the $\mathrm{C}_{2} \mathrm{H}_{2}$ reduction method with ${ }^{15} \mathrm{~N}_{2}$ fixation, measured in parallel incubations in the field. We selected three sampling locations that exhibited high rates of $\mathrm{C}_{2} \mathrm{H}_{2}$ 
reduction and we took three intact soil cores as well as three sets of litter samples, separated for leaflets and rachis. One set of these samples was incubated for $\mathrm{C}_{2} \mathrm{H}_{2}$ reduction assay, as described above, and the other two sets for ${ }^{15} \mathrm{~N}_{2}$-fixation measurements. For the latter, one set of samples was incubated in the same glass jars described above with ambient air and the other set with ${ }^{15} \mathrm{~N}$ enriched air, obtained by exchanging $100 \mathrm{~mL}$ of the headspace with ${ }^{15} \mathrm{~N}_{2}\left(98 \%{ }^{15} \mathrm{~N}\right.$, Cambridge, Isotope Laboratories, Inc.). We measured the $\mathrm{O}_{2}$ concentrations in the headspace every day during the incubation period, using an Oxymeter (Greisinger GmbH 3691, Greisinger Messtechnik GmbH, Regenstauf, Germany). We stopped the incubation when $\mathrm{O}_{2}$ concentrations in the jars' headspace had decreased, resulting in 4-days incubation for leaflets, 3-days incubation for rachis and 10-days incubation for soil cores. For both sets of samples, with and without ${ }^{15} \mathrm{~N}_{2}$, headspace samples $(20 \mathrm{~mL})$ were taken at the beginning and at the end of the incubation, and these were analyzed for ${ }^{15} \mathrm{~N}_{2}$ enrichment with an isotope ratio mass spectrometer (IRMS, Finnigan Deltaplus XP, Thermo Electron Corporation, Bremen, Germany). After the incubation, the soil and litter samples were air-dried, sieved (for the soil), ground and analyzed for total $\mathrm{N}$ using a CN analyzer (Vario EL Cube, Elementar Analysis Systems GmbH, Hanau, Germany) as well as ${ }^{15} \mathrm{~N}$ enrichment using an IRMS. We calculated ${ }^{15} \mathrm{~N}_{2}$ fixation following Keuter et al. (2014):

$$
{ }^{15} N_{\text {fix }}=\left({ }^{15} N_{e}-{ }^{15} N_{r a}\right) \times\left({ }^{15} N_{N 2}-{ }^{15} N_{a}\right)^{-1} \times(N) \times(t){ }^{-1} \times(m)^{-1}
$$

where ${ }^{15} \mathrm{~N}_{\text {fix }}=\mathrm{N}_{2}$ fixation rate $\left(\mathrm{mol} \mathrm{N} \mathrm{Ng}^{-1} \mathrm{~d}^{-1}\right) ;{ }^{15} \mathrm{~N}_{\mathrm{e}}=$ atom $\%{ }^{15} \mathrm{~N}$ of the sample incubated with ${ }^{15} \mathrm{~N}_{2}$-enriched headspace; ${ }^{15} \mathrm{~N}_{\text {ra }}=$ atom $\%{ }^{15} \mathrm{~N}$ natural abundance of the sample incubated with ambient air; ${ }^{15} \mathrm{~N}_{\mathrm{N} 2}$ = average atom $\%{ }^{15} \mathrm{~N}$ of the headspace of the ${ }^{15} \mathrm{~N}_{2}$-enriched sample at the start and end of incubation period; ${ }^{15} \mathrm{~N}_{\mathrm{a}}=$ atom $\%{ }^{15} \mathrm{~N}$ natural abundance of the headspace of the unlabeled sample; $\mathrm{N}=$ total $\mathrm{N}$ concentration of the sample incubated with ${ }^{15} \mathrm{~N}_{2}$-enriched headspace $\left(\mathrm{mg} \mathrm{N} \mathrm{kg}^{-1}\right) ; \mathrm{t}=$ incubation time 
(d); $\mathrm{m}=$ molar mass of $\mathrm{N}_{2}\left(\mathrm{mg} \mathrm{mol}^{-1}\right)$. The conversion factor was calculated as the ratio between $\mathrm{C}_{2} \mathrm{H}_{4}$ production (measured from the $\mathrm{C}_{2} \mathrm{H}_{2}$ reduction assay in $\mathrm{mol}_{2} \mathrm{H}_{4} \mathrm{~kg}^{-1}$ $\left.\mathrm{d}^{-1}\right)$ and ${ }^{15} \mathrm{Nfix}$.

On each measurement date, parallel to the incubations for $\mathrm{N}_{2}$ fixation, we took one intact soil core $\left(250 \mathrm{~cm}^{3}\right)$ in the top $5 \mathrm{~cm}$ and one hand-collected litter sample on the same sampling locations for determination of extractable $\mathrm{N}$. The soil core was broken up directly in the field and mixed in a plastic bag, and large roots were removed. We extracted immediately the soil and separately the litter by placing a subsample into prepared extraction bottles containing $150 \mathrm{~mL}$ of $0.5 \mathrm{M} \mathrm{K}_{2} \mathrm{SO}_{4}$ solution. These bottles were brought to the laboratory, shaken for 1 hour, and filtered through $\mathrm{K}_{2} \mathrm{SO}_{4}$-prewashed filter papers ( $4 \mu \mathrm{m}$ nominal pore size). The extracts were immediately frozen and kept frozen during the transport to the University of Göttingen, Germany. The N concentration in the extracts was measured by ultraviolet-persulfate digestion followed by hydrazine sulfate reduction using a continuous flow injection colorimetry (SEAL Analytical AA3, SEAL Analytical GmbH, Norderstadt, Germany). Also, $\mathrm{C}$ and nutrient contents were measured in the litter from samples of four months (September, October, November 2017, and February 2018), which were air-dried and ground after the incubation for $\mathrm{C}_{2} \mathrm{H}_{2}$ reduction measurements. Total $\mathrm{C}$ and total $\mathrm{N}$ were measured with a $\mathrm{CN}$ analyzer (described above) and other nutrients (P, Mo, Ca, $\mathrm{Mg}, \mathrm{K}, \mathrm{Na}, \mathrm{Al}, \mathrm{Fe}, \mathrm{Mn}$ ) by pressure digestion as decribed above.

\subsubsection{Statistical analyses}

Differences in asymbiotic $\mathrm{N}_{2}$ fixation among treatments and management zones were tested on the monthly measurements (including zero rates of $\mathrm{N}_{2}$ fixation) and on the annual values as these were trapezoidal interpolations. We used linear mixed effect (LME) models (Pinheiro et al. 2019) from the log-transformed rates of asymbiotic $\mathrm{N}_{2}$ fixation as these data showed non-normal distribution. In LME models, treatment or 
management zone was considered as fixed effect whereas replicate plot with nested subplot and sampling day were considered as random effects. Fixed effect was assessed with one-way analysis of variance (ANOVA) followed by Tukey HSD test for multiple comparisons. To assess temporal relationships with controlling factors across the measurement period, we used the Spearman rank correlation test between asymbiotic $\mathrm{N}_{2}$ fixation with extractable $\mathrm{N}$ and moisture content separately for each management zone as well as for frond rachis and leaflets; this test used the average of replicate plots on each sampling day, and thus for soil $n=48$ (12 monthly measurements $x 4$ treatments), and for frond litter $n=32$ (8 monthly measurements $x 4$ treatments). For spatial relationships with controlling factors across replicate plots and management zones, we tested correlations of asymbiotic $\mathrm{N}_{2}$ fixation with extractable $\mathrm{N}$ and moisture content (using their averages over the measurement period) as well as with the soil and litter properties, and these were carried out separately for the soil ( $\mathrm{n}=48=16$ plots $\times 3$ management zones) and frond litter ( $n=32=16$ plots $\times 2$ litter parts). All tests were considered statistically significant at $\mathrm{p} \leq 0.05$. Statistical analyses were carried out using R version 3.6.1 (R Core Team 2019).

\subsection{Results}

\subsubsection{Asymbiotic nitrogen fixation in soil and litter}

The conversion factors of $\mathrm{C}_{2} \mathrm{H}_{4}$ production to $\mathrm{N}_{2}$ fixation were 2.8 for the soil, 10.6 for the leaflets, and 40.9 for the rachis. There were no differences in soil asymbiotic $\mathrm{N}_{2}$ fixation among treatments in all management zones (all $\mathrm{p} \geq 0.09$; Table 1). Instead, there were clear differences among the management zones in all treatments (all $\mathrm{p}<$ 0.01) with the highest rates in the palm circle and the lowest in the frond-stacked area (Table 1). Monthly soil asymbiotic $\mathrm{N}_{2}$ fixation did not show any specific pattern: there was no difference between the months when fertilizers were applied and the rest of the 
months ( $\mathrm{p}>0.1$ for all management zones), and there was no difference between the dry and wet season $(\mathrm{p}>0.1)$, except for the inter-row where asymbiotic $\mathrm{N}_{2}$ fixation was higher in the dry than wet seasons $(p=0.03)$.

Table 1: Annual rates of asymbiotic $\mathrm{N}_{2}$ fixation (mean $\pm \mathrm{SE}, \mathrm{n}=4$ plots) in the top-5$\mathrm{cm}$ depth mineral soil at each treatment and management zone as well as in the frond litter, placed at every second inter-row, in a large-scale oil palm plantation in Jambi, Indonesia.

\begin{tabular}{|c|c|c|c|c|}
\hline Treatment & $\begin{array}{l}\text { Soil } \\
\text { management } \\
\text { zone }\end{array}$ & $\begin{array}{l}\text { Asymbiotic } \\
\mathrm{N}_{2} \text { fixation } \\
\mathrm{mg} \mathrm{N} \mathrm{kg}^{-1} \text { soil } \mathrm{yr}^{-1}\end{array}$ & $\begin{array}{l}\text { Frond } \\
\text { litter } \\
\text { part }\end{array}$ & $\begin{array}{l}\text { Asymbiotic } \\
\mathrm{N}_{2} \text { fixation } \\
\mathrm{mg} \mathrm{N} \mathrm{kg}^{-1} \text { litter } \mathrm{yr}^{-1}\end{array}$ \\
\hline \multirow{3}{*}{ ch } & Palm circle & $2.9 \pm 0.0 \mathrm{a}$ & Leaflets & $84 \pm 63 a$ \\
\hline & Inter-row & $4.1 \pm 2.0 \mathrm{a}$ & Rachis & $17 \pm 7 a$ \\
\hline & Frond-stacked & $0.7 \pm 0.3 b$ & & \\
\hline \multirow[b]{2}{*}{$\mathrm{cW}$} & Palm circle & $3.9 \pm 1.4 \mathrm{a}$ & Leaflets & $15 \pm 2 \mathrm{a}$ \\
\hline & $\begin{array}{l}\text { Inter-row } \\
\text { Frond-stacked }\end{array}$ & $\begin{array}{l}2.0 \pm 0.3 \mathrm{a} \\
0.6 \pm 0.2 \mathrm{~b}\end{array}$ & Rachis & $11 \pm 3 a$ \\
\hline \multirow[b]{2}{*}{ rh } & Palm circle & $5.8 \pm 1.6 \mathrm{a}$ & Leaflets & $19 \pm 7 a$ \\
\hline & $\begin{array}{l}\text { Inter-row } \\
\text { Frond-stacked }\end{array}$ & $\begin{array}{l}2.7 \pm 0.7 \mathrm{ab} \\
1.0 \pm 0.4 \mathrm{~b}\end{array}$ & Rachis & $80 \pm 55 a$ \\
\hline \multirow[b]{2}{*}{ rw } & Palm circle & $3.6 \pm 9.8 \mathrm{a}$ & Leaflets & $39 \pm 10 a$ \\
\hline & $\begin{array}{l}\text { Inter-row } \\
\text { Frond-stacked }\end{array}$ & $\begin{array}{l}1.8 \pm 0.7 \mathrm{ab} \\
0.8 \pm 0.3 \mathrm{~b}\end{array}$ & Rachis & $46 \pm 17 \mathrm{a}$ \\
\hline
\end{tabular}

Means with different letters indicate significant differences among management zones or between frond litter parts within each treatment (linear mixed-effects model on repeated measurements followed by ANOVA with Tukey HSD at $p \leq 0.05$ ). There was no significant differences among treatments $(\mathrm{p}>0.05)$.

Annual rates are calculated by linear interpolation between monthly measured rates and sampling day intervals.

Treatments: $\mathrm{ch}=$ conventional fertilization-herbicide; $\mathrm{cw}=$ conventional fertilization-mechanical weeding; $r$ h = reduced fertilization-herbicide; $r w=$ reduced fertilization-mechanical weeding

For frond litter, there were no differences in asymbiotic $\mathrm{N}_{2}$ fixation among treatments or frond parts (all $\mathrm{p}>0.1$; Table 1). Similarly to the soil, the monthly litter asymbiotic $\mathrm{N}_{2}$ fixation did not exhibit a specific pattern and there was no difference between dry and wet seasons ( $\mathrm{p} \leq 0.07$ for both frond parts). 
The annual rates of asymbiotic $\mathrm{N}_{2}$ fixation on mass basis were clearly larger in the frond litter compared to the soil, but, given the low amount of piled frond litter in the plantation, the annual rates on the ground-area basis were larger in the soil than the litter (Table 2). The total (top $5 \mathrm{~cm}$ mineral soil + frond litter) asymbiotic $\mathrm{N}_{2}$ fixation in the plantation was $1.9 \pm 0.2 \mathrm{~kg} \mathrm{~N} \mathrm{ha}^{-1} \mathrm{yr}^{-1}$.

Table 2: Area-based extrapolation of annual rates of asymbiotic $\mathrm{N}_{2}$ fixation (mean \pm $\mathrm{SE}, \mathrm{n}=4$ plots) in the top-5-cm depth mineral soil $(a)$ and in the frond litter $(b)$ in a large-scale oil palm plantation in Jambi, Indonesia.

\begin{tabular}{|c|c|c|c|c|c|}
\hline $\begin{array}{l}\text { a) Soil } \\
\text { management } \\
\text { zone }\end{array}$ & $\begin{array}{l}\text { Average } \\
\text { asymbiotic } \\
\mathrm{N}_{2} \text { fixation } \\
\text { across all plots } \\
\mathrm{mg} \mathrm{N} \mathrm{kg}^{-1} \text { soil yr }{ }^{-1}\end{array}$ & $\begin{array}{l}\text { Area } \\
\text { cover }\end{array}$ & $\begin{array}{l}\text { Area-weighted } \\
\text { asymbiotic } \\
\mathrm{N}_{2} \text { fixation } \\
\mathrm{mg} \mathrm{N} \mathrm{kg}^{-1} \text { soil } \mathrm{yr}^{-1}\end{array}$ & $\begin{array}{l}\text { Average } \\
\text { soil } \\
\text { bulk } \\
\text { density } \\
\mathrm{g} \mathrm{cm}^{-3}\end{array}$ & $\begin{array}{l}\text { Area-based } \\
\text { asymbiotic } \\
\mathrm{N}_{2} \text { fixation } \\
\mathrm{kg} \mathrm{N} \mathrm{ha}^{-1} \mathrm{yr}^{-1}\end{array}$ \\
\hline $\begin{array}{l}\text { Palm circle } \\
\text { Inter-row } \\
\text { Frond- } \\
\text { stacked }\end{array}$ & $\begin{array}{l}4.0 \pm 0.7 \\
2.7 \pm 0.5 \\
0.8 \pm 0.2\end{array}$ & $\begin{array}{l}18 \\
67 \\
15\end{array}$ & $2.6 \pm 0.3$ & 1.2 & $1.6 \pm 0.2$ \\
\hline $\begin{array}{l}\text { b) Frond } \\
\text { litter part }\end{array}$ & $\begin{array}{l}\text { Average } \\
\text { asymbiotic } \\
\mathrm{N}_{2} \text { fixation } \\
\text { across all plots } \\
\mathrm{mg} \mathrm{N} \mathrm{kg}^{-1} \text { litter } \mathrm{yr}^{-1}\end{array}$ & $\begin{array}{l}\text { Frond } \\
\text { parts }\end{array}$ & $\begin{array}{l}\text { Frond } \\
\text { part-weighted } \\
\text { asymbiotic } \\
\mathrm{N}_{2} \text { fixation } \\
\mathrm{mg} \mathrm{N} \mathrm{kg}^{-1} \text { litter } \mathrm{yr}^{-1}\end{array}$ & $\begin{array}{l}\text { Average } \\
\text { amount } \\
\text { of frond } \\
\text { litter } \\
\mathrm{kg} \mathrm{dw} \mathrm{m}^{-2}\end{array}$ & $\begin{array}{l}\text { Asymbiotic } \\
\mathrm{N}_{2} \text { fixation } \\
\mathrm{kg} \mathrm{N} \mathrm{ha}^{-1} \mathrm{yr}^{-1}\end{array}$ \\
\hline $\begin{array}{l}\text { Leaflets } \\
\text { Rachis }\end{array}$ & $\begin{array}{l}39 \pm 17 \\
38 \pm 13\end{array}$ & $\begin{array}{l}46 \\
54\end{array}$ & $39 \pm 9$ & 0.8 & $0.3 \pm 0.1$ \\
\hline
\end{tabular}

Treatments: $\mathrm{ch}=$ conventional fertilization-herbicide; $\mathrm{cw}=$ conventional fertilization-mechanical weeding; rh = reduced fertilization-herbicide; rw = reduced fertilization-mechanical weeding

\subsubsection{Controlling factors of asymbiotic nitrogen fixation}

Soil biochemical characteristics were not affected by management practices by the differed among management zones (Table S1). The frond-stacked area had higher gross $\mathrm{N}$ mineralization than the other management zones ( $\mathrm{p}<0.01$; Fig. 2, Table S1) and had higher extractable $\mathrm{N}$ than the inter-row ( $\mathrm{p}<0.01$; Fig. 2$)$. The palm circle had lower gross $\mathrm{N}$ mineralization than the inter-row ( $\mathrm{p}=0.01$; Fig. 2 , Table S1) and higher soil 
Table 3: Frond litter characteristics (mean $\pm S E, n=4$ plots in a large-scale oil palm plantation in Jambi, Indonesia.

\begin{tabular}{llll}
\hline Frond litter characteristics & Leaflets & Rachis \\
\hline Moisture content & $\mathrm{kg} \mathrm{kg}^{-1}$ & $1.25 \pm 0.05 \mathrm{~b}$ & $1.56 \pm 0.01 \mathrm{a}$ \\
Total C & $\mathrm{g} \mathrm{kg}^{-1}$ & $484.7 \pm 1.8 \mathrm{a}$ & $479.1 \pm 1.8 \mathrm{~b}$ \\
Total N & $\mathrm{g} \mathrm{kg}^{-1}$ & $17.9 \pm 0.4 \mathrm{a}$ & $8.1 \pm 0.4 \mathrm{~b}$ \\
C:N ratio & & $29 \pm 1 \mathrm{~b}$ & $65 \pm 2 \mathrm{a}$ \\
$\mathrm{Ca}$ & $\mathrm{g} \mathrm{kg}^{-1}$ & $7.8 \pm 0.2 \mathrm{~b}$ & $8.8 \pm 0.4 \mathrm{a}$ \\
$\mathrm{Mg}$ & $\mathrm{g} \mathrm{kg}^{-1}$ & $2.07 \pm 0.09 \mathrm{~b}$ & $2.25 \pm 0.16 \mathrm{a}$ \\
$\mathrm{K}$ & $\mathrm{g} \mathrm{kg}^{-1}$ & $1.44 \pm 0.09 \mathrm{a}$ & $1.34 \pm 0.08 \mathrm{a}$ \\
$\mathrm{S}$ & $\mathrm{g} \mathrm{kg}^{-1}$ & $0.96 \pm 0.05 \mathrm{~b}$ & $1.16 \pm 0.03 \mathrm{a}$ \\
$\mathrm{P}$ & $\mathrm{mg} \mathrm{kg}^{-1}$ & $820 \pm 46 \mathrm{~b}$ & $924 \pm 52 \mathrm{a}$ \\
$\mathrm{Al}$ & $\mathrm{mg} \mathrm{kg}^{-1}$ & $527 \pm 115 \mathrm{a}$ & $517 \pm 82 \mathrm{a}$ \\
Extractable N & $\mathrm{mg} \mathrm{kg}^{-1}$ & $226 \pm 19 \mathrm{a}$ & $190 \pm 10 \mathrm{~b}$ \\
Fe & $\mathrm{mg} \mathrm{kg}^{-1}$ & $170 \pm 26 \mathrm{a}$ & $184 \pm 18 \mathrm{a}$ \\
$\mathrm{Na}$ & $\mathrm{mg} \mathrm{kg}^{-1}$ & $83 \pm 6 \mathrm{a}$ & $79 \pm 6 \mathrm{a}$ \\
$\mathrm{Mn}$ & $\mathrm{mg} \mathrm{kg}^{-1}$ & $58 \pm 10 \mathrm{a}$ & $75 \pm 9 \mathrm{~b}$ \\
Mo & $\mu \mathrm{g} \mathrm{kg}^{-1}$ & $56 \pm 6 \mathrm{a}$ & $57 \pm 9 \mathrm{a}$ \\
\hline
\end{tabular}

Means with different letters indicate significant differences between frond litter parts (linear mixed effect model with ANOVA at $\mathrm{p} \leq 0.05$ ).

Values are the average of the treatments and of the repeated measurements (extractable $\mathrm{N}$ and moisture content measured eight times, others measured 4 times).

$\mathrm{pH}$ than the other zones ( $\mathrm{p}<0.01$; Fig. 2, Table S1). Litter biochemical characteristics differed among frond parts, wwith higher $\mathrm{C}$, and $\mathrm{N}$ (total and extractable) contents in the leaflets and higher $\mathrm{C}: \mathrm{N}$ ratio, moisture, $\mathrm{Ca}, \mathrm{Mg}, \mathrm{S}, \mathrm{P}, \mathrm{Mn}$ contents in the rachis, whereas the other nutrients were comparable among the two (all $\mathrm{p} \leq 0.05$; Table 3 ).

Temporal correlations between asymbiotic $\mathrm{N}_{2}$ fixation and soil properties were not consistent across management zones. Only the inter-row asymbiotic $\mathrm{N}_{2}$ fixation showed a negative correlation with extractable $N(R=-0.47, p=0.001, n=48)$. Additionally, only the frond rachis asymbiotic $\mathrm{N}_{2}$ fixation showed positive correlation with moisture content $(\mathrm{R}=0.36, \mathrm{p}=0.03, \mathrm{n}=32)$. Spatial relationships across plots and management zones showed negative correlations of soil asymbiotic $\mathrm{N}_{2}$ fixation with 
extractable $\mathrm{N}$ and gross $\mathrm{N}$ mineralization, and a positive correlation with $\mathrm{pH}$ (Fig. 2).

Figure 2: Spearman rank correlations between soil asymbiotic $\mathrm{N}_{2}$ fixation (averaged across year-round monthly measurements) and soil properties, measured in the top 5 -cm depth ( $\mathrm{n}=48 ; 3$ management zones $x 16$ plots $)$ in a large-scale oil palm plantation in Jambi, Indonesia.

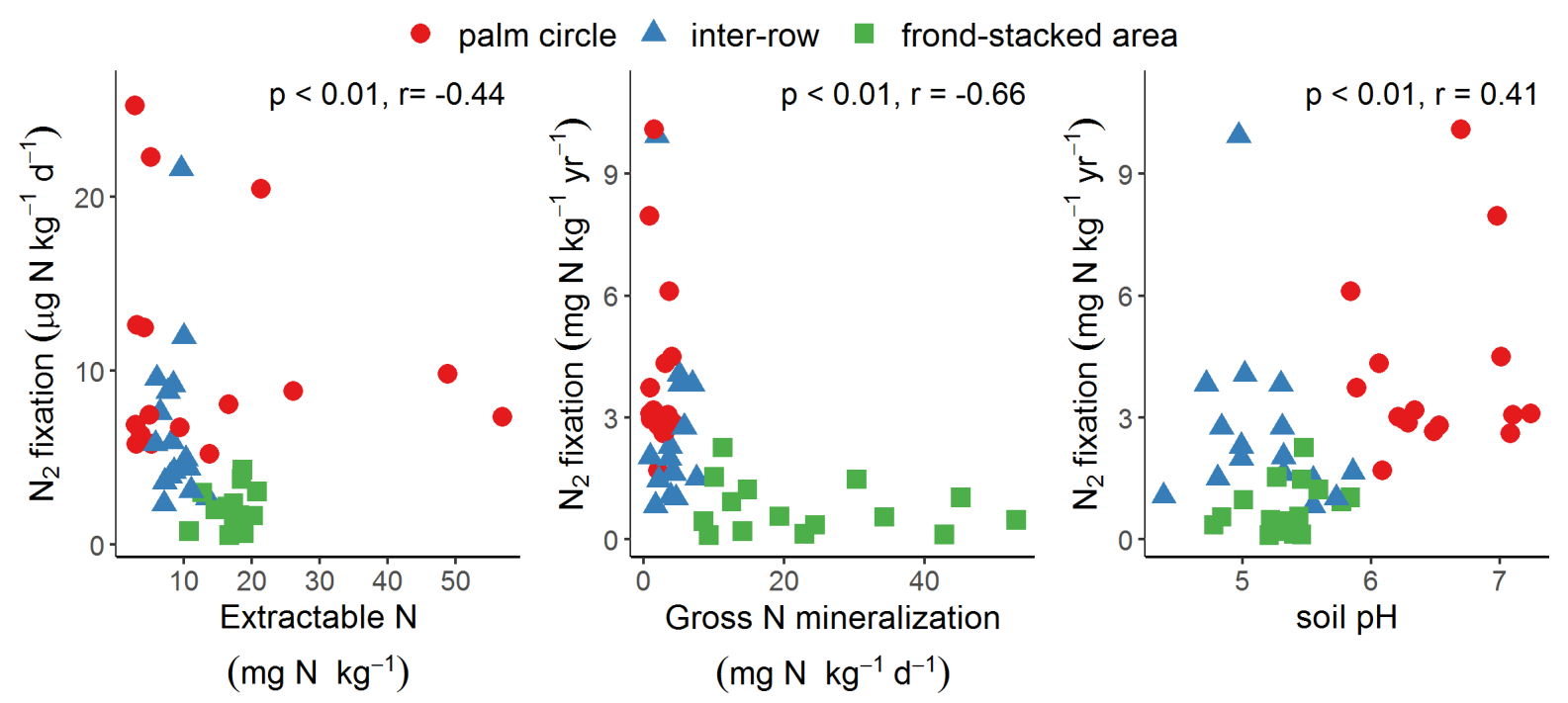

\subsection{Discussion}

\subsubsection{Asymbiotic nitrogen fixation in oil palm plantations}

The measured conversion factor for soil was close to the theoretical value of 3 (Hardy et al. 1968). The high conversion factor measured for the frond litter could be due to its high water content: $\mathrm{C}_{2} \mathrm{H}_{2}$ is more soluble in water than $\mathrm{N}_{2}$, and low dissolution of $\mathrm{N}_{2}$ in samples with high water content and incubated with ambient air might limit $\mathrm{N}_{2}$ fixation (Nohrstedt 1983a). The high gravimetric water content in our incubated frond litter, especially in rachis (Table 3), seems to be in line with this hypothesis. Nevertheless, other studies on litter $\mathrm{N}_{2}$ fixation also reported large conversion factor in temperate (8.5, Roskoski 1981) and tropical forests (3.9 in Hawaii, Vitousek and Hobbie 2000; 7.9 in Panama, Barron et al. 2009), showing that the deviation from the theoretical value of 3 is common. Our results show that different substrates (e.g. soil, leaflets 
and rachis) can have different conversion factors and so they highlight the importance of measuring the conversion factor in each studied system and for each substrate, especially when the values from the $\mathrm{C}_{2} \mathrm{H}_{2}$ reduction assay are used for extrapolation to ecosystem level.

The asymbiotic $\mathrm{N}_{2}$ fixation rates in our highly weathered Acrisol soil for the top $5 \mathrm{~cm}$ (Table 2) were similar, but slightly lower, than the rates reported for unfertilized Eucalyptus plantations on Acrisol soil in China $\left(4.0 \mathrm{~kg} \mathrm{~N} \mathrm{ha}^{-1} \mathrm{yr}^{-1}\right.$ for the top $10 \mathrm{~cm}$, Zheng et al. 2016). Comparing with tropical forests, our rates were somewhat lower than the rates for a forest on Ultisol soil in Puerto Rico ( $4.3 \mathrm{~kg} \mathrm{~N} \mathrm{ha}^{-1} \mathrm{yr}^{-1}$ for the top $10 \mathrm{~cm}$, Cusack et al. 2009) but higher than in a forest on Ultisol soil in Costa Rica (1.3 $\mathrm{kg} \mathrm{N} \mathrm{ha}^{-1} \mathrm{yr}^{-1}$ for the top $10 \mathrm{~cm}$, Reed et al. 2007). The asymbiotic $\mathrm{N}_{2}$ fixation rates of oil palm leaf litter (Table 2) were much lower than those from forest litter in Costa Rica (555 mg N kg litter ${ }^{-1} \mathrm{yr}^{-1}$, Reed et al. 2007), but similar to rates for tropical forests in Panama (28-31 mg N kg litter ${ }^{-1} \mathrm{yr}^{-1}$, Wurzburger et al. 2012) and higher than rates in French Guyana (20 mg N kg litter ${ }^{-1} \mathrm{yr}^{-1}$, van Langenhove et al. 2019) all on highly weathered Ferralsol or Acrisol soils. We conclude that our measured rates of $\mathrm{N}_{2}$ fixation were in the range reported in literature for tropical forests, even if this comparison don't include data of asymbiotic $\mathrm{N}_{2}$ fixation in Asian tropical forests, for which there is virtually no study (Davies-Barnard and Friedlingstein 2020).

Our study is the first to provide robust estimates of annual asymbiotic $\mathrm{N}_{2}$ fixation in an oil palm plantation (Table 3), which is one of the key unknowns in the $\mathrm{N}$ budget of this land use (Pardon et al. 2016). The contribution of asymbiotic $\mathrm{N}_{2}$ fixation to the $\mathrm{N}$ budget was small, if compared to atmospheric $\mathrm{N}$ deposition of $12.9 \mathrm{~kg} \mathrm{~N}^{-1}$ $\mathrm{yr}^{-1}$ (Kurniawan et al. 2018) and to the fertilization rates of $260 \mathrm{~kg} \mathrm{~N} \mathrm{ha}^{-1} \mathrm{yr}^{-1}$. It is likely that asymbiotic $\mathrm{N}_{2}$ fixation was reduced by land-use conversion from forest to oil palm, given that in our study area oil palm plantations have lower abundance of N-fixing bacteria compared to the reference forest (Berkelmann et al. 2018). We have to 
point out that other compartments that can be additional sources of fixed $\mathrm{N}$ were not measured in this study, such as canopy soil (Matson et al. 2015), epiphytes (Benner et al. 2007), lichens (Matzek and Vitousek 2003) and mosses (Cusack et al. 2009). However, given their limited coverage, the contribution to the plantation $\mathrm{N}$ budget is likely very small. Nevertheless, the high rates of asymbiotic $\mathrm{N}_{2}$ fixation per litter amount point to the importance of retaining the senesced fronds in the plantation as an additional source of $\mathrm{N}$, as well as a source of organic matter and nutrients to the soil (Table 3). Therefore, management practices should aim at increasing the retention of litter in the plantation.

\subsubsection{Effects of management practices and controlling factors of asym- biotic nitrogen fixation}

Contrary to our second hypothesis, there was no effect of reduced management practices on asymbiotic $\mathrm{N}_{2}$ fixation. Similarly, a study in a Eucalyptus plantation in Brazil found that the addition of $\mathrm{N}$ and $\mathrm{P}$ did not affect soil asymbiotic $\mathrm{N}_{2}$ fixation (Bomfim et al. 2019) and attributed it to the influence of previous fertilization regimes in the plantation. Indeed, the conventional management has been ongoing since the plantation establishment, whereas the reduced management practices were employed only four months prior to the start of our year-round measurements. This was further supported by comparable soil nutrient contents among experimental treatments (Table S1). These findings signified that the reduction in management intensity will take years to impact asymbiotic $\mathrm{N}_{2}$ fixation, which may have been reduced after two decades of high fertilization following forest conversion.

Nevertheless, in line with our first hypothesis, we found differences in soil asymbiotic $\mathrm{N}_{2}$ fixation among management zones, demonstrating that oil palm management practices shaped the spatial pattern of asymbiotic $\mathrm{N}_{2}$ fixation. The negative correlations of soil $\mathrm{N}_{2}$ fixation rates with extractable $\mathrm{N}$ and gross $\mathrm{N}$ mineralization (Fig. 
2) suggest that high $\mathrm{N}$ availability diminished this process, as shown for tropical soils in forests (Cusack et al. 2009, Matson et al. 2015) and plantations (Zheng et al. 2016). This correlation was clearly driven by the frond-stacked area with the highest soil Ncycling rates and $\mathrm{N}$ contents (Fig. 2), derived from the regularly piled senesced fronds. The regular addition of frond litter into this frond-stacked area maintained steadily high extractable $\mathrm{N}$ concentrations during our year-round of measurements explaining the consistently low asymbiotic $\mathrm{N}_{2}$ fixation. Interestingly, the palm circle showed low extractable $\mathrm{N}$ contents (Fig. 2), except the months following the bi-annual $\mathrm{N}$ fertilization, suggesting that the $\mathrm{N}$ applied was either quickly taken up by the palms, or translocated beyond our measured top-5-cm depth, or lost via leaching and gaseous emissions (Dubos et al. 2017, Hassler et al. 2017, Kurniawan et al. 2018). This hypothesis is also supported by the lack of fertilization effect on asymbiotic $\mathrm{N}_{2}$ fixation and the lack of temporal correlation with $\mathrm{N}$ contents. Even though we found some peaks of high soil $\mathrm{N}$ concentrations after fertilization, they were detectable just when the sampling time was close to the fertilization day and they were variable across space given that the fertilizer was applied in the form of granulates, resulting in high variability in the extractable $\mathrm{N}$ concentrations (Fig. 2). In the inter-row the intermediate levels of extractable $\mathrm{N}$ (Fig. 2) negatively correlated with asymbiotic $\mathrm{N}_{2}$ fixation across the monthly measurements, further affirming the control of available $\mathrm{N}$ in regulating $\mathrm{N}_{2}$ fixation rates. Another important controlling factor for spatial variations of soil asymbiotic $\mathrm{N}_{2}$ fixation was soil $\mathrm{pH}$, which was higher in the palm circle (due to lime application) than in the other zones (Fig. 2; Table S1). Soil pH is one of the most important factors explaining spatial variations of bacterial community in tropical forests (Tripathi et al. 2014) as well as the shift in bacterial community following conversion of forest to oil palm plantations in our study region (Schneider et al. 2015). Abundance of diazotrophic bacteria is reduced in acidic soils (Mirza et al. 2014, Liang et al. 2016, Liao et al. 2018). In addition, $\mathrm{pH}$ determines the availability of $\mathrm{P}$ in the soil, since in acidic 
soils P is fixed by Al- and Fe-oxides and rendered unavailable for plants and microorganisms (Schlesinger and Bernhardt 2013). It has been found that $\mathrm{P}$ is an important controlling factor for asymbiotic $\mathrm{N}_{2}$ fixation in tropical soils (Matson et al. 2015, van Langenhove et al. 2019), and therefore the correlation of asymbiotic $\mathrm{N}_{2}$ fixation with $\mathrm{pH}$ could in part be the result of differences in available $\mathrm{P}$ between these zones. These point out to the importance of investigating $\mathrm{P}$ limitation of asymbiotic $\mathrm{N}_{2}$ fixation in oil palm plantations.

On the other hand, there was no difference in litter asymbiotic $\mathrm{N}_{2}$ fixation between leaflets and rachis, even if the latter reported generally more favorable conditions for $\mathrm{N}_{2}$ fixation, as lower $\mathrm{N}$, and higher moisture and P contents (Table 1). It may be that the main controlling factor for litter asymbiotic $\mathrm{N}_{2}$ fixation in this plantation was Mo, which was comparable among frond parts (Table 3). Indeed a review on litter asymbiotic $\mathrm{N}_{2}$ fixation in tropical forests suggested that Mo concentrations lower than $100 \mu \mathrm{g} \mathrm{kg}^{-1}$ resulted in Mo limitation rather than P limitation (Reed et al. 2013). The lack of spatial and temporal correlations between litter asymbiotic $\mathrm{N}_{2}$ fixation and controlling factors is likely the results of the low variability of litter characteristics, which were not different among treatments or replicate plots, against the high variability of the litter sampled (see high standard errors), given the intrinsic heterogeneity of litter in space and time. The high spatial and temporal variability of our litter samples show the importance of having replicates and repeated measurements, in order to include the inherent variability of litter for extrapolation to ecosystem level.

\subsection{Conclusion}

Our study is, to our knowledge, the first to measure asymbiotic $\mathrm{N}_{2}$ fixation in mature oil palm plantations and it provides a robust estimate of annual rates of asymbiotic $\mathrm{N}_{2}$ fixation from soil and litter. Differences in asymbiotic $\mathrm{N}_{2}$ fixation among management zones show that management practices influence the spatial patterns of fixation 
by regulating the nutrient concentrations in the soil. In the frond-stacked area the accumulation of litter returns high $\mathrm{N}$ to the soil that restrain asymbiotic $\mathrm{N}_{2}$ fixation in this zone, whereas in the palm circle lime application increases soil $\mathrm{pH}$ resulting in higher asymbiotic $\mathrm{N}_{2}$ fixation. Litter asymbiotic $\mathrm{N}_{2}$ fixation is comparable in the leaflets and in the rachis and is probably limited by Mo. Future research should focus on evaluating other possible controlling factors for asymbiotic $\mathrm{N}_{2}$ fixation in soil (e.g. P and Mo) and investigating diazotrophic bacteria abundance and microbial community composition in oil palm plantations. As regarding our management experiment, there was no effect of reduced management on asymbiotic $\mathrm{N}_{2}$ fixation at this early stage of the experiment, but some effects may arise in the long run, given the differences found between management zones. Finally, the high rates of $\mathrm{N}$ fixed by the litter, point out to the importance of pile the senescent fronds in the plantation rather than export them from the field.

\section{Acknowledgements}

This research is part of the sub-project A05 of the Collaborative Research Center 990 EFForTs project (Ecological and Socioeconomic Functions of Tropical Lowland Rainforest Transformation Systems), funded by the Deutsche Forschungsgemeinschaft (DFG, Project ID: 192626868 - SFB 990). We acknoweldge Perkebunan Nusantara VI (PTPN VI) for granting the experiment establishment in their plantation, as well as Kevin Darras and the sub-project Z01 for the management of this experiment. We thank our Indonesian assistants, Happy Chandra, Fajar Sidik and Sofyan Raden for their precious help in the field and in the laboratory. We also thank the laboratory staff in Goettingen from the department of Tropical Soil Science and from the Centre for Stable Isotope Research and Analysis, Reinhard Langel and Lars Szwec. This research was conducted under the research permit 539351/SIP/FRP/E5/Dit.KI/X/2016. 


\section{Declaration of author contribution}

GF carried out the experiment, conducted the data analysis and wrote the manuscript with support from MDC. EV and MDC conceptualized the study design, methodologies and laboratory analyses. AT facilitated field access, logistical support, collaborator agreements and material exports.

\subsection{Supplementary material}

Table S1: Soil biochemical properties in the top-5-cm soil depth (mean \pm SE, $\mathrm{n}=4$ plots) in the different management zones in a large-scale oil palm plantation in Jambi, Indonesia. Data from Chapter 2.

\begin{tabular}{|c|c|c|c|}
\hline Characteristics & $\begin{array}{l}\text { Frond- } \\
\text { stacked }\end{array}$ & Inter-row & Palm circle \\
\hline Gross $\mathrm{N}$ mineralization $\left(\mathrm{mg} \mathrm{N} \mathrm{kg}^{-1} \mathrm{~d}^{-1}\right)$ & $2.3 \pm 0.3 c$ & $4.2 \pm 0.8 \mathrm{~b}$ & $24.4 \pm 5.0 \mathrm{a}$ \\
\hline Soil organic $C\left(\mathrm{~g} \mathrm{C} \mathrm{kg}^{-1}\right)$ & $47.6 \pm 5.3 a$ & $12.2 \pm 0.6 b$ & $11.9 \pm 1.4 b$ \\
\hline Total N ( $\left.\mathrm{g} \mathrm{N} \mathrm{kg}^{-1}\right)$ & $2.9 \pm 0.3 \mathrm{a}$ & $0.9 \pm 0.1 b$ & $0.8 \pm 0.1 b$ \\
\hline Soil C:N ratio & $16.0 \pm 0.3 \mathrm{a}$ & $14.1 \pm 0.2 b$ & $15.1 \pm 0.3 \mathrm{ab}$ \\
\hline $\operatorname{ECEC~}\left(\mathrm{mmol}_{\mathrm{C}} \mathrm{kg}^{-1}\right)$ & $113 \pm 13 a$ & $22 \pm 2 c$ & $72 \pm 7 b$ \\
\hline Base saturation (\%) & $96 \pm 1 b$ & $59 \pm 6 c$ & $100 \pm 0 \mathrm{a}$ \\
\hline $\mathrm{pH}($ & $6.51 \pm 0.05 a$ & $5.17 \pm 0.06 b$ & $5.33 \pm 0.12 a$ \\
\hline Bulk density $\left(\mathrm{g} \mathrm{cm}^{-3}\right)$ & $0.52 \pm 0.06 \mathrm{a}$ & $1.20 \pm 0.04 b$ & $1.23 \pm 0.04 b$ \\
\hline Moisture content ( $\mathrm{kg}$ water $\left.\mathrm{kg}^{-1}\right)$ & $0.19 \pm 0.01 b$ & $0.21 \pm 0.01 b$ & $0.50 \pm 0.12 \mathrm{a}$ \\
\hline Temperature $\left({ }^{\circ} \mathrm{C}\right)$ & $26.0 \pm 0.3 \mathrm{a}$ & $25.5 \pm 0.4 \mathrm{a}$ & $25.8 \pm 0.5 \mathrm{a}$ \\
\hline Soil $\delta^{15} \mathrm{~N}$ natural abundance $(\%)$ & $2.3 \pm 0.3 b$ & $4.3 \pm 0.2 \mathrm{a}$ & $5.0 \pm 0.1 \mathrm{a}$ \\
\hline
\end{tabular}

For each parameter, different letters indicate significant differences among management zones (one-way ANOVA with Tukey HSD or Kruskal-Wallis H test with multiple comparisons extension at $p \leq 0.05$ ).

$\mathrm{ECEC}=$ effective cation exchange capacity. 


\section{References}

- Allen K, Corre MD, Tjoa A, Veldkamp E (2015) Soil nitrogen-cycling responses to conversion of lowland forests to oil palm and rubber plantations in Sumatra, Indonesia. PloS One 10(7):e0133325. doi:10.1371/journal.pone.0133325

- Barnes AD, Allen K, Kreft H, Corre MD, Jochum M, Veldkamp E, Clough Y, Daniel R, Darras K, Denmead LH, Farikhah Haneda N, Hertel D, Knohl A, Kotowska MM, Kurniawan S, Meijide A, Rembold K, Edho Prabowo W, Schneider D, Tscharntke T, Brose U (2017) Direct and cascading impacts of tropical land-use change on multi-trophic biodiversity. Nature Ecology and Evolution 1(10):1511-1519. doi:10.1038/s41559-017-0275-7

- Barron AR, Wurzburger N, Bellenger JP, Wright SJ, Kraepiel AML, Hedin LO (2009) Molybdenum limitation of asymbiotic nitrogen fixation in tropical forest soils. Nature Geoscience 2(1):42-45. doi:10.1038/ngeo366

- Benner JW, Conroy S, Lunch CK, Toyoda N, Vitousek PM (2007) Phosphorus fertilization increases the abundance and nitrogenase activity of the cyanolichen Pseudocyphellaria Crocata in Hawaiian montane forests. Biotropica 39(3):400-405. doi:10.1111/j.1744-7429.2007.00267.x

- Berkelmann D, Schneider D, Engelhaupt M, Heinemann M, Christel S, Wijayanti M, Meryandini A, Daniel R (2018) How rainforest conversion to agricultural systems in Sumatra (Indonesia) affects active soil bacterial communities. Frontiers in Microbiology 9:2381. doi:10.3389/fmicb.2018.02381

- Blake GR, Hartge KH (1986) Bulk density

- Bomfim B, Silva LCR, Doane TA, Horwath WR (2019) Interactive effects of land-use change and topography on asymbiotic nitrogen fixation in the Brazilian Atlantic Forest. Biogeochemistry 142(1):137-153. doi:10.1007/s10533-018-0525-z

- Carter C, Finley W, Fry J, Jackson D, Willis L (2007) Palm oil markets and future supply. European Journal of Lipid Science and Technology 109(4): 307-314. doi:10.1002/ejlt.200600256

- Cleveland CC, Townsend AR, Schimel DS, Fisher H, Howarth RW, Hedin LO, Perakis SS, Latty EF, Fischer JC von, Elseroad A, Wasson MF (1999) Global patterns of terrestrial biological nitrogen (N2) fixation in natural ecosystems. Global Biogeochemical Cycles 13(2):623-645. doi:10.1029/1999GB900014

- Corley RHV, Tinker PB (2016) The oil palm, 5th ed. John Wiley \& Sons, Ltd, Hoboken, NJ 
- Cusack DF, Silver W, McDowell WH (2009) Biological nitrogen fixation in two tropical forests: ecosystem-level patterns and effects of nitrogen fertilization. Ecosystems 12(8):1299-1315. doi:10.1007/s10021-009-9290-0

- Darras KFA, Corre MD, Formaglio G, Tjoa A, Potapov A, Brambach F, Sibhatu KT, Grass I, Rubiano AA, Buchori D, Drescher J, Fardiansah R, Hölscher D, Irawan B, Kneib T, Krashevska V, Krause A, Kreft H, Li K, Maraun M, Polle A, Ryadin AR, Rembold K, Stiegler C, Scheu S, Tarigan S, Valdés-Uribe A, Yadi S, Tscharntke T, Veldkamp E (2019) Reducing fertilizer and avoiding herbicides in oil palm plantations-ecological and economic valuations. Frontiers in Forests and Global Change 2. doi:10.3389/ffgc.2019.00065

- Davies-Barnard T, Friedlingstein P (2020) The global distribution of biological nitrogen fixation in terrestrial natural ecosystems. Global Biogeochemical Cycles. doi:10.1029/2019GB006387

- Directorate General of Estate Crop (2017) Tree crop estate statistics of Indonesia 2015 - 2017: palm oil

- Dubos B, Snoeck D, Flori A (2017) Excessive use of fertilizer can increase leaching processes and modify soil reserves in two Ecuadorian oil palm plantations. Experimental Agriculture 53(2):255-268. doi:10.1017/S0014479716000363

- FAO (2018) Food and Agricolture Organization, FAOSTAT. http:/ / faostat.fao.org/site/339/default.aspx. Accessed 30 Mar 2020

- Galloway JN, Schlesinger WH, Levy H, Michaels A, Schnoor JL (1995) Nitrogen fixation: anthropogenic enhancement-environmental response. Global Biogeochemical Cycles 9(2):235-252. doi:10.1029/95GB00158

- Hardy RWF, Holsten RD, Jackson EK, Burns RC (1968) The acetylene-ethylene assay for N2 fixation: laboratory and field evaluation. Plant Physiology 43(8):1185-1207. doi:10.1104/pp.43.8.1185

- Haron K, Brookes PC, Anderson JM, Zakaria ZZ (1998) Microbial biomass and soil organic matter dynamics in oil palm (Elaeis Guineensis Jacq.) plantations, West Malaysia. Soil Biology and Biochemistry 30(5):547-552.

doi:10.1016/S0038-0717(97)00217-4

- Hassler E, Corre MD, Kurniawan S, Veldkamp E (2017) Soil nitrogen oxide fluxes from lowland forests converted to smallholder rubber and oil palm plantations in Sumatra, Indonesia. Biogeosciences 14:2781-2798. doi:10.5194/bg-14-2781-2017

- Hassler E, Corre M d., Tjoa A, Damris M, Utami SR, Veldkamp E (2015) Soil fertility controls soil-atmosphere carbon dioxide and methane fluxes in a tropical landscape 
converted from lowland forest to rubber and oil palm plantations. Biogeosciences 12(19):5831-5852. doi:10.5194/bg-12-5831-2015

- Hedin LO, Brookshire EJ, Menge DNL, Barron AR (2009) The nitrogen paradox in tropical forest ecosystems. Annual Review of Ecology, Evolution, and Systematics 40(1):613-635. doi:10.1146/annurev.ecolsys.37.091305.110246

- Hofmockel KS, Schlesinger WH (2007) Carbon dioxide effects on heterotrophic dinitrogen fixation in a temperate pine forest. Soil Science Society of America Journal 71(1):140. doi:10.2136/sssaj2006.110

- Hyman MR, Arp DJ (1987) Quantification and removal of some contaminating gases from acetylene used to study gas-utilizing enzymes and microorganisms. Applied and Environmental Microbiology 53(2):298-303

- Keuter A, Veldkamp E, Corre MD (2014) Asymbiotic biological nitrogen fixation in a temperate grassland as affected by management practices. Soil Biology and Biochemistry 70:38-46. doi:10.1016/j.soilbio.2013.12.009

- Kotowska MM, Leuschner C, Triadiati T, Hertel D (2016) Conversion of tropical lowland forest reduces nutrient return through litterfall, and alters nutrient use efficiency and seasonality of net primary production. Oecologia 180:601-618. doi:10.1007/s00442-015-3481-5

- Kurniawan S, Corre MD, Matson AL, Schulte-Bisping H, Utami SR, van Straaten O, Veldkamp E (2018) Conversion of tropical forests to smallholder rubber and oil palm plantations impacts nutrient leaching losses and nutrient retention efficiency in highly weathered soils. Biogeosciences 15:5131-5154. doi:10.5194/bg-15-5131-2018

- Liang Y, Pan F, He X, Chen X, Su Y (2016) Effect of vegetation types on soil arbuscular mycorrhizal fungi and nitrogen-fixing bacterial communities in a karst region. Environ Sci Pollut Res 23(18):18482-18491. doi:10.1007/s11356-016-7022-5

- Liao H, Li Y, Yao H (2018) Fertilization with inorganic and organic nutrients changes diazotroph community composition and $\mathrm{N}$-fixation rates. Journal of Soils and Sediments 18(3):1076-1086. doi:10.1007/s11368-017-1836-8

- Luke SH, Purnomo D, Advento AD, Aryawan AAK, Naim M, Pikstein RN, Ps S, Rambe TDS, Soeprapto, Caliman J-P, Snaddon JL, Foster WA, Turner EC (2019) Effects of understory vegetation management on plant communities in oil palm plantations in Sumatra, Indonesia. Frontiers in Forests and Global Change 2:1-13. doi:10.3389/ffgc.2019.00033

- Matson AL, Corre MD, Burneo JI, Veldkamp E (2015) Free-living nitrogen fixation responds to elevated nutrient inputs in tropical montane forest floor and canopy soils 
of southern Ecuador. Biogeochemistry 122(2-3):281-294.

doi:10.1007/s10533-014-0041-8

- Matzek V, Vitousek P (2003) Nitrogen fixation in bryophytes, lichens, and decaying wood along a soil-age gradient in Hawaiian montane rain forest. Biotropica 35(1):12-19. doi:10.1111/j.1744-7429.2003.tb00257.x

- Mirza BS, Potisap C, Nüsslein K, Bohannan BJM, Rodrigues JLM (2014) Response of free-living nitrogen-fixing microorganisms to land use change in the Amazon rainforest. Applied and Environmental Microbiology 80(1): 281-288. doi:10.1128/AEM.02362-13

- Moradi A, Teh CBS, Goh KJ, Husni MHA, Ishak CF (2014) Decomposition and nutrient release temporal pattern of oil palm residues. Annals of Applied Biology 164:208-219. doi:10.1111/aab.12094

- Nohrstedt H-Ö (1983a) Conversion factor between acetylene reduction and nitrogen fixation in soil: effect of water content and nitrogenase activity. Soil Biology and Biochemistry 15(3):275-279. doi:10.1016/0038-0717(83)90071-8

- Nohrstedt H-Ö (1983b) Natural formation of ethylene in forest soils and methods to correct results given by the acetylene-reduction assay. Soil Biology and Biochemistry 15(3):281-286. doi:10.1016/0038-0717(83)90072-X

- Pinheiro J, Bates D, DebRoy S, Sarkar D, R Core Team (2019) Linear and nonlinear mixed effects models. $R$ package version 3.1-139

- R Core Team (2019) R: A language and environment for statistical computing. Foundation for Statistical Computing, Vienna, Austria

- Rahman N, Bruun TB, Giller KE, Magid J, Ven GWJ, Neergaard A (2019) Soil greenhouse gas emissions from inorganic fertilizers and recycled oil palm waste products from Indonesian oil palm plantations. GCB Bioenergy 214(2): 107. doi:10.1111/gcbb.12618

- Reed SC, Cleveland CC, Townsend AR (2007) Controls over leaf litter and soil nitrogen fixation in two lowland tropical rain forests. Biotropica 39(5): 585-592. doi:10.1111/j.1744-7429.2007.00310.x

- Reed SC, Cleveland CC, Townsend AR (2011) Functional ecology of free-living nitrogen fixation: a contemporary perspective. Annual Review of Ecology, Evolution, and Systematics 42(1):489-512. doi:10.1146/annurev-ecolsys-102710-145034 - Reed SC, Cleveland CC, Townsend AR (2013) Relationships among phosphorus, molybdenum and free-living nitrogen fixation in tropical rain forests: results from observational and experimental analyses. Biogeochemistry 114 (1-3): 135-147. doi:10.1007/s10533-013-9835-3 
- Rembold K, Mangopo H, Tjitrosoedirdjo SS, Kreft H (2017) Plant diversity, forest dependency, and alien plant invasions in tropical agricultural landscapes. Biological Conservation 213:234-242. doi:10.1016/j.biocon.2017.07.020

- Roskoski JP (1981) Comparative C2H2 reduction and 15N2 fixation in deciduous wood litter. Soil Biology and Biochemistry 13(1):83-85.

doi:10.1016/0038-0717(81)90109-7

- Rüegg J, Quezada JC, Santonja M, Ghazoul J, Kuzyakov Y, Buttler A, Guillaume T (2019) Drivers of soil carbon stabilization in oil palm plantations. Land Degrad Dev 30 (16):1-12. doi:10.1002/ldr.3380

- Schlesinger WH, Bernhardt ES (2013) Biogeochemistry. An analysis of global change, 3rd ed. Academic Press, Waltham, Mass

- Schneider D, Engelhaupt M, Allen K, Kurniawan S, Krashevska V, Heinemann M, Nacke H, Wijayanti M, Meryandini A, Corre MD, Scheu S, Daniel R (2015) Impact of lowland rainforest transformation on diversity and composition of soil prokaryotic communities in Sumatra (Indonesia). Frontiers in Microbiology 6:1339. doi:10.3389/fmicb.2015.01339

- Tripathi BM, Lee-Cruz L, Kim M, Singh D, Go R, Shukor NAA, Husni MHA, Chun J, Adams JM (2014) Spatial scaling effects on soil bacterial communities in Malaysian tropical forests. Microb Ecol 68(2):247-258

- van Langenhove L, Depaepe T, Vicca S, van den Berge J, Stahl C, Courtois E, Weedon J, Urbina I, Grau O, Asensio D, Peñuelas J, Boeckx P, Richter A, van der Straeten D, Janssens IA (2019) Regulation of nitrogen fixation from free-living organisms in soil and leaf litter of two tropical forests of the Guiana shield. Plant and Soil 253-254:114. doi:10.1007/s11104-019-04012-1

- Vitousek PM, Hobbie S (2000) Heterotrophic nitrogen fixation in decomposing litter: patterns and regulation. Ecology 81(9):2366-2376.

doi:10.1890/0012-9658(2000)081[2366:HNFIDL]2.0.CO;2

- Wurzburger N, Bellenger JP, Kraepiel AML, Hedin LO (2012) Molybdenum and phosphorus interact to constrain asymbiotic nitrogen fixation in tropical forests. PloS One 7(3):e33710. doi:10.1371/journal.pone.0033710

- Zheng M, Chen H, Li D, Zhu X, Zhang W, Fu S, Mo J (2016) Biological nitrogen fixation and its response to nitrogen input in two mature tropical plantations with and without legume trees. Biology and Fertility of Soils 52(5):665-674. doi:10.1007/s00374-016-1109-5 


\title{
Chapter 4
}

\section{Herbicide weed control increases}

\author{
nutrient leaching as compared to
}

mechanical weeding in a large-scale oil

\section{palm plantation}

Greta Formaglio, Edzo Veldkamp, Xiaohong Duan, Aiyen Tjoa, Marife D. Corre 


\section{Abstract}

Nutrient leaching in intensively managed oil palm plantations can diminish soil fertility and water quality. There is a need to reduce this environmental footprint without sacrificing yield. We quantified nutrient leaching in a large-scale oil palm plantation on Acrisol soil with factorial treatment combinations of two fertilization rates $(260 \mathrm{~N}$, $50 \mathrm{P}, 220 \mathrm{~K} \mathrm{~kg} \mathrm{ha}^{-1} \mathrm{yr}^{-1}$ as conventional practice, and $136 \mathrm{~N}, 17 \mathrm{P}, 187 \mathrm{~K} \mathrm{~kg} \mathrm{ha}^{-1} \mathrm{yr}^{-1}$, equal to harvest export, as reduced management) and two weeding methods (conventional herbicide, and mechanical weeding as reduced management). Each of the four treatment combinations was represented by a $2500-\mathrm{m}^{2}$ plot, replicated in four blocks. In each plot, soil-pore water was collected monthly at 1.5-m depth for one year in three management zones: palm circle, inter-row, and frond-stacked area. In the palm circle, nutrient leaching was low due to low solute concentrations and small drainage fluxes, resulting from large plant uptake. Conversely, in the inter-row, nitrate and aluminum leaching losses were high due to their high concentrations, large drainage fluxes, low plant uptake, and acidic $\mathrm{pH}$. In the frond-stacked area, base cation leaching was high, presumably from frond litter decomposition, but $\mathrm{N}$ leaching was low. Mechanical weeding, even with conventional high fertilization rates, reduced leaching losses of all nutrients. Mechanical weeding with reduced fertilization had the lowest $\mathrm{N}$ and base cation leaching whereas its yield and economic gross margin remain comparable with the conventional management practices. Herbicide weed control decreased ground vegetation, and thereby reduced efficiency of soil nutrient retention. Our findings signified that mechanical weeding and reduced fertilization should be included in the Indonesian Ministry of Agriculture program for precision farming (e.g. variable rates with plantation age), particularly for large-scale plantations, and in the science-based policy recommendations, such as those endorsed by the Roundtable for Sustainable Palm Oil association. 


\subsection{Introduction}

Agricultural expansion is a major driver of tropical deforestation (Geist and Lambin 2002), which have global impacts on reducing carbon sequestration (Asner et al. 2010, van Straaten et al. 2015), greenhouse gas regulation (e.g. Meijide et al. 2020, Murdiyarso et al. 2010), and biodiversity (e.g Clough et al. 2016) and increasing profit gains at the expense of ecosystem multifunctionality (Grass et al. 2020). Oil palm is the most important rapidly expanding tree-cash crop that replaces tropical forest in Southeast Asia (Gibbs et al. 2010, Carlson et al. 2013) due to its high yield with low production costs and rising global demand (Carter et al. 2007, Corley 2009). Currently, Indonesia produces $57 \%$ of palm oil worldwide (FAO 2018) and this production is projected to expand in the future, threatening the remaining tropical forest (Vijay et al. 2016, Pirker et al. 2016). Forest to oil palm conversion is associated with a decrease in soil fertility, because of high nutrient export via harvest, reduced rates of soil-N cycling, and decreases in soil organic carbon (SOC) and nutrient stocks (Allen et al. 2015, Allen et al. 2016, van Straaten et al. 2015). The decline in soil fertility reinforces the dependency on fertilizer inputs, and a severe decline can lead to abandonment of the area with further expansion of oil palm plantations in another, exacerbating land-use change. Leaching can contribute to the impoverishment of soil nutrients as well as reduction in water quality and eutrophication of water bodies. Increased nutrient loads to water bodies due to agricultural expansion and intensification, common in temperate areas (Carpenter et al. 1998), are increasingly reported for tropical regions (Figueiredo et al. 2010, Teklu et al. 2018). Given the typically high precipitation rates, leaching losses can possibly be large in intensively managed plantations in the tropics, although deeply weathered tropical soils also have the capacity to store large quantities of $\mathrm{N}$ and P (Jankowski et al. 2018, Neill et al. 2013). Indeed, $\mathrm{NO}_{3}{ }^{-}$, the most leachable form of $\mathrm{N}$, can be retained in the subsoil by anion exchange capacity of highly weathered acidic soils (Wong et 
al. 1990) whereas $\mathrm{P}$ can be fixed to Fe and Al (hydr)oxides of tropical soils (Roy et al. 2016). Nevertheless, there are some evidences of streamwater quality reductions due to oil palm cultivation in Malaysia (Luke et al. 2017, Tokuchi et al. 2019), signifying the importance of quantifying nutrient leaching losses in other areas with expansive oil palm plantations, especially in Jambi, Indonesia, one of the hotspots of forest conversion to oil palm in Indonesia (Drescher et al. 2016).

Although oil palm plantations can possibly have low leaching losses, as a consequence of high evapotranspiration and thus low drainage fluxes (Tarigan et al. 2020), most of oil palm plantations are large-scale enterprises that are characterized by intensive management with high fertilization rates and herbicide application. Intensive agriculture in the tropics is associated with high $\mathrm{N}$ leaching losses (Huddell et al. 2020). Even in tree-cash or perennial crop plantations, with generally higher evapotranspiration and deeper rooting depth than annual crops, high fertilization rates result in sustained, large nutrient leaching losses (e.g. Cannavo et al. 2013, Wakelin et al. 2011). Large $\mathrm{NO}_{3}{ }^{-}$leaching from high $\mathrm{N}$ fertilization is always accompanied by leaching of cations (Cusack et al. 2009, Dubos et al. 2017), impoverishing highly weathered tropical soils that are inherently low in base cations (Allen et al. 2016, Kurniawan et al. 2018). Fertilization is necessary to support high yields of oil palm plantations, but reduction in fertilization rates, e.g. to levels that compensate for nutrient export through harvest, may reduce nutrient leaching losses while maintaining high productivity. On the other hand, the use of herbicide for weed control can exacerbate nutrient leaching losses, as prolonged absence of ground vegetation reduces uptake of redistributed nutrients from applied fertilizers far from reach of crop roots (Abdalla et al., 2019). Herbicide weeding, common in large-scale oil palm plantation, is practiced in the area where the fertilizers are applied, to reduce competition for nutrients and water with ground vegetation, and in the inter-rows, to facilitate access during harvest (Corley and Tinker 2016). However, herbicide not only eradicates aboveground vegetative parts but also 
removes roots slowing down regeneration. In contrast, mechanical weeding only removes aboveground part, allowing relatively fast regeneration of ground vegetation, which could take up redistributed nutrients and could reduce leaching losses.

To investigate nutrient leaching losses in an oil palm plantation, the spatial structure created by the planting design and by the management practices must be taken into account, which is only partly considered in the sampling designs of previous studies. Three management zones in oil palm plantations can be identified: (1) the palm circle, an area around the palm's trunk where the fertilizers are applied and weeded; (2) the inter-row, weeded less frequently than the palm circle but unfertilized; and (3) the frond-stacked area, usually every second inter-row, where the cut senesced fronds are piled up. In these management zones, the interplay of water fluxes, root uptake and soil nutrient contents determine the extent of nutrient leaching losses. The palm circle despite having direct fertilization have also large water and nutrient uptake (Nelson et al. 2006) because of high root density (Lamade et al. 1996) such that large leaching losses may only occur following pulse high fertilization and during high drainage (from high precipitation) events (Banabas et al. 2008a). The inter-row experiences higher water input from precipitation than the palm circle because of lower canopy interception (Banabas et al. 2008b), and large water flux within the soil because of low root uptake, stimulating nutrient transport to lower depths. However, as there is no direct fertilizer application on the inter-row, nutrient leaching may be low. The frond-stacked area receives nutrients from decomposition of nutrient-rich fronds (Kotowska et al. 2016) and such mulching with senesced fronds prevents run-off and promotes water infiltration as a consequence of enhanced macroporosity by increased organic matter (Moradi et al. 2015). High water infiltration may generate high water drainage fluxes, resulting in intermediate nutrient leaching losses in the frond-stacked area.

In this study, we aimed to quantify nutrient leaching losses in an intensively 
managed, large-scale oil palm plantation, and to assess if reduced intensity of management (i.e. reduced fertilization rates equal to harvest export and mechanical weeding) can reduce leaching losses in oil palm plantations. We tested these hypotheses: (1) leaching losses in the palm circle will be larger than in the other management zones because of direct fertilizer application; (2) leaching losses under herbicide application will be higher than mechanical weeding because of slower regeneration of ground vegetation that can augment nutrient retention; (3) nutrient leaching fluxes under conventional high fertilization rates will be substantial compared to reduced rates because of excessive nutrient inputs. Our study provides a systematic quantification of an important environmental footprint of oil palm production, taking into consideration its spatial variation in management zones, and evaluates the effectiveness of alternative management practices for leaching reduction.

\subsection{Materials and Methods}

\subsubsection{Study area and experimental design}

This study was conducted in a state-owned oil palm plantation in Jambi province, Indonesia ( $1^{\circ} 43^{\prime} 8^{\prime \prime} \mathrm{S}, 103^{\circ} 23^{\prime} 53^{\prime \prime} \mathrm{E}, 73 \mathrm{~m}$ above sea level). Mean annual air temperature is $26.7 \pm 1.0^{\circ} \mathrm{C}$ and mean annual precipitation is $2235 \pm 385 \mathrm{~mm}$ (1991-2011; data from Sultan Thaha airport, Jambi). During our study period (March 2017-February 2018), the mean daily air temperature was $26.3^{\circ} \mathrm{C}$ and annual precipitation was $2772 \mathrm{~mm}$, with a dry period between July and October (precipitation $<140 \mathrm{~mm} \mathrm{month}^{-1}$ ). The soil is highly weathered, loam Acrisol soil (Allen et al. 2015) and nutrient inputs from bulk precipitation in the area, measured in 2013, were $12.9 \mathrm{~kg} \mathrm{~N}, 0.4 \mathrm{~kg} \mathrm{P}, 5.5 \mathrm{~kg} \mathrm{~K} \mathrm{ha}^{-1}$ $\mathrm{yr}^{-1}$ (Kurniawan et al. 2018).

This oil palm plantation was established between 1998 and 2002, and so the palms were 16-20 years old during our study period. The plantation encompassed 
2025 ha, with a planting density of approximately 142 palms ha $^{-1}$, spaced $8 \mathrm{~m}$ apart on rows. The rows between palms are used alternately for harvesting operations and to pile-up senesced fronds, which are regularly cut to facilitate harvesting of fruits; this frond-stacked area covers $15 \%$ of the plantation. The palm circle, 2-m radius from the trunk, wherein fertilizers are applied and weeded four times a year, covers $18 \%$ of the plantation. The remaining $67 \%$ can be classified as inter-row, which is not fertilized but weeded two times a year.

In November 2016, a two (fertilization rates) by two (weeding methods) factorial management experiment was established in this plantation as part of the framework of the EFForTS project, described in detail by Darras et al. (2019). For fertilization treatments, the conventional rates were $260 \mathrm{~N}, 50 \mathrm{P}, 220 \mathrm{~K} \mathrm{~kg} \mathrm{ha}^{-1} \mathrm{yr}^{-1}$, whereas the reduced rates were $136 \mathrm{~N}, 17 \mathrm{P}, 187 \mathrm{~K} \mathrm{~kg} \mathrm{ha}^{-1} \mathrm{yr}^{-1}$. Reduced fertilization rates were determined to compensate for nutrient exports via fruit harvest and were based on the nutrient concentrations measured in the fruit bunches multiplied by the annual yield. The fertilizer sources were urea $\left(\mathrm{CH}_{4} \mathrm{~N}_{2} \mathrm{O}\right)$, triple superphosphate $\left(\mathrm{Ca}\left(\mathrm{H}_{2} \mathrm{PO}_{4}\right)_{2} \mathrm{H}_{2} \mathrm{O}\right)$ and muriate of potash $(\mathrm{KCl})$, and these were applied according to the plantation's standard practices: split in two applications per year (in April and October), applied in a band within a 2-m radius from the palm, and this area was raked before fertilizer application. For both fertilization treatments, lime (426 kg dolomite ha $\left.{ }^{-1} \mathrm{yr}^{-1} ; \mathrm{CaMg}\left(\mathrm{CO}_{3}\right)_{2}\right)$ and micronutrients (142 kg micro-mag ha ${ }^{-1} \mathrm{yr}^{-1}$ with $0.5 \% \mathrm{~B}_{2} \mathrm{O}_{3}, 0.5 \% \mathrm{CuO}, 0.25 \%$ $\mathrm{Fe}_{2} \mathrm{O}_{3}, 0.15 \% \mathrm{ZnO}, 0.1 \% \mathrm{MnO}$ and $18 \% \mathrm{MgO}$ ) were also applied besides the $\mathrm{N}, \mathrm{P}$ and $\mathrm{K}$ fertilizers, as commonly practiced in large-scale plantations on acidic Acrisol soils (Pahan 2010). For weeding treatments, the conventional method was the use of herbicide (glyphosate), whereas the reduced method was mechanical weeding using a brush cutter. Glyphosate was applied following plantation's standard practice: $1.5 \mathrm{~L} \mathrm{ha}^{-1} \mathrm{yr}^{-1}$ to the palm circle, split four times a year, and $0.75 \mathrm{~L} \mathrm{ha}^{-1} \mathrm{yr}^{-1}$ to the inter-row, split two times a year. The mechanical weeding was carried out in the same areas and frequen- 
cies as herbicide application. This management experiment comprised of four replicate blocks and each had four plots (50 m x $50 \mathrm{~m}$ each) assigned to four treatment combinations: conventional rate-herbicide, conventional rate-mechanical weeding, reduced rate-herbicide, and reduced rate-mechanical weeding.

\subsubsection{Soil water sampling}

We collected monthly soil-pore water samples over one year, using suction cup lysimeters (P80 ceramic, maximum pore size $1 \mu \mathrm{m}$; CeramTec AG, Marktredwitz, Germany). We installed the lysimeters in January 2017, choosing two palms per plot and sampling in the three management zones: (1) in the palm circle, at $1 \mathrm{~m}$ from the palm trunk, (2) in the frond-stacked area, at about $4 \mathrm{~m}$ from the palm trunk, and (3) in the inter-row, at approximately $4 \mathrm{~m}$ from the palm trunk (Fig. S1). In total, 96 lysimeters were installed (4 treatment plots $\times 4$ replicates $\times 2$ subplots $\times 3$ management zones). The lysimeters were inserted into the soil till $1.5-\mathrm{m}$ depth, so that the soil-pore water was collected well below the rooting depth of $1 \mathrm{~m}$ which is common to oil palm plantations on loam Acrisol soils near our study site (Kurniawan et al. 2018). Starting in March 2017, soil water was sampled by applying $40 \mathrm{kPa}$ vacuum (Kurniawan et al. 2018, Dechert et al. 2005) to the lysimeters and collected in dark glass bottles, which were stored in a bucket buried in the field. Once a week, we transferred the collected water into plastic bottles and transported them to the field station, where they were stored frozen. The collection continued over a month until a volume of $100 \mathrm{~mL}$ was collected from each lysimeter, or until the end of the month. The frozen water samples were transported by air freight to the University of Göttingen, Germany, where element concentrations

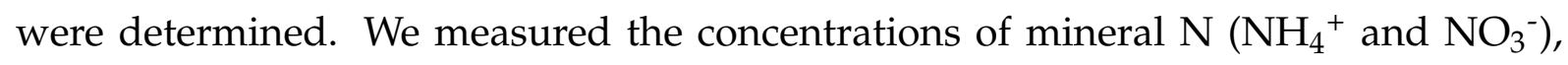
total dissolved $\mathrm{N}$ (TDN) and $\mathrm{Cl}$ by continuous flow injection colorimetry (SEAL Analytical AA3, SEAL Analytical GmbH, Norderstadt, Germany), as described in details by Kurniawan et al. (2018). Dissolved organic N (DON) was calculated as the differ- 
ence between TDN and mineral N. We measured the concentrations of base cations $(\mathrm{Na}, \mathrm{K}, \mathrm{Ca}, \mathrm{Mg}$ ), total $\mathrm{Al}$, total $\mathrm{Fe}$, total $\mathrm{Mn}$, total $\mathrm{S}$, and total $\mathrm{P}$ with an inductively coupled plasma-atomic emission spectrometer (iCAP 6300; Thermo Fischer Scientific $\mathrm{GmbH}$, Dreieich, Germany).

We determined a partial cation-anion charge balance of the major elements (concentrations $0.03 \mathrm{mg} \mathrm{L}^{-1}$ ) in soil-pore water by converting the concentrations to $\mu \mathrm{mol}_{\text {charge }}$ $\mathrm{L}^{-1}$. We assumed $\mathrm{S}$ to be in the form of sulfate $\left(\mathrm{SO}_{4}{ }^{2-}\right)$ and total $\mathrm{Al}$ to have a charge of $3+$. We calculated the contribution of organic acids $\left(\mathrm{RCOO}^{-}\right)$and bicarbonate $\left(\mathrm{HCO}_{3}^{-}\right)$ as the difference between the measured cations and anions (Kurniawan et al. 2018).

\subsubsection{Modeling water drainage}

The water balance was modeled using the water sub-model of the Expert-N software, version 5.0 (Priesack 2005), which was successfully used to estimate drainage fluxes from different land uses in Indonesia (Dechert et al. 2005, Kurniawan et al. 2018). The model inputs were climate data (solar radiation, temperature, precipitation, relative humidity, and wind speed), and soil (texture, bulk density, and hydraulic functions) and vegetation characteristics (biomass, leaf area index, and root distribution). The climate data were taken from the climatological station in the plantation (described in detail by Meijide et al. 2017), and the oil palm biomass was taken from a study on oil palm plantations near our study site (Kotowska et al. 2015). Soil bulk density and porosity in the top $10 \mathrm{~cm}$ were measured in each management zone at our study site, whereas for the 10-50-cm depth these were measured in the inter-row, assuming that the differences in soil bulk density among management zones would be minimal below the topsoil. Data for soil bulk density and porosity for the 50-200-cm depth, as well as soil texture, soil hydraulic parameters (i.e. water retention curve, saturated hydraulic conductivity and Van Genuchten parameters for the water retention curve), and root distribution were taken from Allen et al. (2015) and Kurniawan et al. (2018), 
choosing their studied oil palm plantations closest to our study site. Expert-N water sub-model calculates daily water drainage based on precipitation, evapotranspiration, canopy interception, runoff, and change in soil water storage. Evapotranspiration is calculated using Penman-Monteith method (Allen 1998), applying a plant factor of 1.06 (Meijide et al. 2017), with plant transpiration based on leaf area index (LAI), plant biomass, and maximum rooting depth. The canopy interception is calculated from the percentage of throughfall and the maximum water storage capacity of the canopy. Runoff is calculated from soil texture and bulk density, which determine the water infiltration rate, and from the slope, which was 5\% (Röll et al. 2019). The vertical water movement is calculated using Richard's equation based on soil hydraulic functions.

To model the drainage in the different management zones, we used the measured soil bulk density and porosity in the top $10 \mathrm{~cm}$ and adjusted other input parameters to simulate differences in water balance in each management zone. For the palm circle, we set the LAI to 3.65, which is the maximum LAI measured at our site (Fan et al. 2015), to simulate high water uptake in the palm circle (Nelson et al. 2006) and maximum rooting depth to $1 \mathrm{~m}$, which is reported for oil palm plantations near our site (Kurniawan et al. 2018). The percentage throughfall in the palm circle was set to $50 \%$ and the water storage capacity of oil palm trunk was set to $8.4 \mathrm{~mm}$ (Tarigan et al. 2018). For the inter-row, we set the LAI and the maximum rooting depth as half of the palm circle (1.8 LAI, 50-cm rooting depth), as roots are shallower between palms (Nelson et al. 2006); the throughfall was set to $10 \%$, and the palm trunk's water storage capacity was set to $4.7 \mathrm{~mm}$ (based on canopy storage capacity reported by Tarigan et al. 2018). For the frond-stacked area, the LAI was set to 0.75, which is half of the minimum measured in the studied plantation (Darras et al. 2019), as understory vegetation is absent at this zone. Values for interception in the frond-stacked area was set to the same values as the inter-row, whereas the runoff was set to 0 , as mulching with senesced fronds slows down runoff (Tarigan et al. 2016). 
For validation of the Expert-N water sub-model outputs, we measured soil water matric potential at depths of $30 \mathrm{~cm}$ and $60 \mathrm{~cm}$ over the study period and compared the measured values with the modeled matric potential. Matric potential was measured by installing a tensiometer (P80 ceramic, maximum pore size $1 \mu \mathrm{m}$; CeramTec AG, Marktredwitz, Germany) at each depth in each management zone near to two palms in two treatments (i.e. conventional rate-herbicide, and reduced rate-mechanical weeding), for a total of 12 tensiometers. We summed the modeled daily drainage at 1.5-m depth to get the monthly drainage fluxes, which we then multiplied with the element concentrations in soil water to get the monthly nutrient leaching fluxes.

\subsubsection{Soil biochemical characteristics and nutrient retention efficiency}

We measured soil biochemical properties in the same sampling locations (Figure S1) at four depth intervals: $0-5 \mathrm{~cm}, 5-10 \mathrm{~cm}, 10-30 \mathrm{~cm}$, and $30-50 \mathrm{~cm}$. Soil samples from the same management zone in each plot were pooled to make one composite sample, totaling to 192 soil samples ( 4 treatments plots $\times 4$ replicates $\times 3$ management zones $\times 4$ depths). The samples were air-dried and sieved $(2 \mathrm{~mm})$ and measured for $\mathrm{pH}(1: 4$ soilto-water ratio) and for effective cation exchange capacity (ECEC), by percolating the soils with unbuffered $1 \mathrm{~mol} \mathrm{~L}^{-1} \mathrm{NH}_{4} \mathrm{Cl}$ and measuring the cations $(\mathrm{Ca}, \mathrm{Mg}, \mathrm{K}, \mathrm{Na}, \mathrm{Al}$, $\mathrm{Fe}, \mathrm{Mn}$ ) in percolates using ICP-AES. A subsample was finely ground and analyzed for organic $\mathrm{C}$ and total $\mathrm{N}$ using a $\mathrm{CN}$ analyzer (Vario EL Cube, Elementar Analysis Systems $\mathrm{GmbH}$, Hanau, Germany), and for ${ }^{15} \mathrm{~N}$ natural abundance signature using isotope ratio mass spectrometer (IRMS; Delta Plus, Finnigan MAT, Bremen, Germany). We calculated the soil element stocks for each depth by multiplying the element concentration with the measured bulk density and summed for the top $50 \mathrm{~cm}$; other soil characteristics (e.g. pH, ECEC, base saturation) in the top $50 \mathrm{~cm}$ soil were calculated as the depth-weighted average of the sampled depths.

In addition, we calculated the $\mathrm{N}$ and base cation retention efficiency in the soil 
for each experimental treatment and management zone following the formula: nutrient retention efficiency $=1-$ (nutrient leaching loss / soil-available nutrient) (Kurniawan et al. 2018). We used the gross $\mathrm{N}$ mineralization rates in the top $5 \mathrm{~cm}$ soil (Table S1) as an index of soil-available $\mathrm{N}$ whereas soil-available base cations was the sum of the stocks of $\mathrm{K}, \mathrm{Na}, \mathrm{Mg}$ and $\mathrm{Ca}$ in the top $10 \mathrm{~cm}$ soil, expressed in $\mathrm{mol}_{\text {charge }} \mathrm{m}^{-2}$.

\subsubsection{Statistical analyses}

For soil biochemical properties measured once, we tested for differences among management zones as well as among experimental treatments for the entire $50-\mathrm{cm}$ depth, using the analysis of variances (ANOVA) with Tukey HSD as a post-hoc test. The soil variables that showed non-normal distribution or unequal variances, tested with Shapiro-Wilk and Levene's tests, respectively, were log-transformed prior to the analysis. Base cation and $\mathrm{N}$ retention efficiency were also tested for differences between experimental treatments in the same way. For repeatedly measured variables, i.e. soilpore water solute concentrations and leaching fluxes, we used linear mixed-effects models (LME; Bates et al. 2015) to assess the differences among management zones and treatments. For testing management zone differences, we conducted the LME with management zone as fixed effect and random effects for sampling months and experimental treatments nested with replicate plots, which were also nested with subplots. For testing treatment differences, we calculated for each replicate plot on each sampling month the area-weighted average of the three management zones (i.e. palm circle accounts for $18 \%$ of the plantation area, the frond-stacked area $15 \%$, and the interrow 67\%), and LME was carried out with treatment as fixed effect and random effects for sampling months and replicate plots nested with subplots. If the residuals of the LME models were not normally distributed, we applied either logarithmic or square root transformation. Differences were assessed with ANOVA (Kuznetsova et al. 2017) followed by Tukey HSD (Hothorn et al. 2008). We also used LME to assess differences 
in soil water matric potential among management zones, with management zone as fixed effect and measurement days and depth nested with treatment as random effects. Comparability between modeled and measured soil water matric potential for each depth in each management zone ( $\mathrm{n}=50$ field measurements) was assessed using Pearson correlation test. All tests were considered significant at $p \leq 0.05$, except for soil $\mathrm{pH}$ which we considered a marginal significance at $\mathrm{p}=0.06$. All statistical analyses were performed with $R$ version 3.6.1 (R Core Team 2019).

\subsection{Results}

\subsubsection{Soil biochemical properties and water balance}

Soil biochemical properties in the top $50 \mathrm{~cm}$ did not differ between experimental treatments (all $\mathrm{p}>0.05$ ) but strongly differed among management zones (Table 1). The frond-stacked area, where senesced fronds were regularly piled like mulch material, had higher SOC and total N stocks $(\mathrm{p}<0.01)$ compared to the other management zones. The inter-row, with regular weeding but without direct fertilizer and lime inputs, showed lower exchangeable base cation contents (i.e. $\mathrm{Ca}, \mathrm{Mg}, \mathrm{K}$ ) compared to the other management zones $(\mathrm{p} \leq 0.02)$ and higher exchangeable $\mathrm{Al}$ content than the palm circle $(p=0.01)$. This was reflected in the lower base saturation and higher $\mathrm{Al}$ saturation in the inter-row compared to the other zones $(\mathrm{p}<0.01)$. Also, inter-row had the lowest ECEC $(\mathrm{p}<0.01)$ and marginally lower $\mathrm{pH}$ than the palm circle $(\mathrm{p}=0.06)$. The palm circle, where fertilizers and lime were applied, had generally comparable exchangeable element contents with the frond-stacked area, except for $\mathrm{K}$, which was higher in the palm circle ( $\mathrm{p}<0.01)$, and for $\mathrm{Mn}$, which was higher in the frond-stacked area $(\mathrm{p}<0.01)$. 
Table 1: Soil physical and biochemical characteristics (mean \pm standard errors, $\mathrm{n}=4$ plots) in the top-50-cm depth for each management zone, averaged across experimental treatments in a large-scale oil palm plantation in Jambi, Indoensia.

\begin{tabular}{lllll}
\hline Soil properties & & Palm circle & Frond-stacked area & Inter-row \\
\hline Bulk density & $\mathrm{g} \mathrm{cm}^{-3}$ & $1.37 \pm 0.01 \mathrm{a}$ & $0.89 \pm 0.01 \mathrm{~b}$ & $1.36 \pm 0.01 \mathrm{~b}$ \\
Soil organic C & $\mathrm{kg} \mathrm{m}^{-2}$ & $6.2 \pm 0.6 \mathrm{~b}$ & $9.1 \pm 0.8 \mathrm{a}$ & $6.4 \pm 0.2 \mathrm{~b}$ \\
Total N & $\mathrm{g} \mathrm{m}^{-2}$ & $402 \pm 31 \mathrm{~b}$ & $571 \pm 39 \mathrm{a}$ & $426 \pm 15 \mathrm{ab}$ \\
soil C:N ratio & & $15.5 \pm 0.5 \mathrm{a}$ & $15.7 \pm 0.3 \mathrm{a}$ & $15.0 \pm 0.5 \mathrm{a}$ \\
$15 \mathrm{~N}$ natural abundance & $\%$ & $5.9 \pm 0.1 \mathrm{a}$ & $5.3 \pm 0.2 \mathrm{a}$ & $5.7 \pm 0.2 \mathrm{a}$ \\
pH & $\left.1: 4 \mathrm{H}_{2} \mathrm{O}\right)$ & $5.05 \pm 0.08 \mathrm{a}$ & $5.00 \pm 0.08 \mathrm{ab}$ & $4.81 \pm 0.05 \mathrm{~b}$ \\
ECEC & $\mathrm{mmol}_{\mathrm{c}} \mathrm{kg}^{-1}$ & $35 \pm 2 \mathrm{a}$ & $28 \pm 2 \mathrm{a}$ & $18 \pm 1 \mathrm{~b}$ \\
Base saturation & $\%$ & $48 \pm 3 \mathrm{a}$ & $46 \pm 4 \mathrm{a}$ & $20 \pm 2 \mathrm{~b}$ \\
Aluminum saturation & $\%$ & $52 \pm 4 \mathrm{~b}$ & $50 \pm 2 \mathrm{~b}$ & $78 \pm 2 \mathrm{a}$ \\
$\mathrm{Mg}$ & $\mathrm{g} \mathrm{m}^{-2}$ & $32 \pm 3 \mathrm{a}$ & $28 \pm 6 \mathrm{a}$ & $9 \pm 1 \mathrm{~b}$ \\
Ca & $\mathrm{g} \mathrm{m}^{-2}$ & $169 \pm 21 \mathrm{a}$ & $157 \pm 15 \mathrm{a}$ & $37 \pm 5 \mathrm{~b}$ \\
$\mathrm{~K}$ & $\mathrm{~g} \mathrm{~m}^{-2}$ & $39 \pm 13 \mathrm{a}$ & $13 \pm 1 \mathrm{~b}$ & $6 \pm 1 \mathrm{~b}$ \\
$\mathrm{Na}$ & $\mathrm{g} \mathrm{m}^{-2}$ & $1.5 \pm 0.4 \mathrm{a}$ & $0.7 \pm 0.2 \mathrm{a}$ & $0.6 \pm 0.2 \mathrm{a}$ \\
$\mathrm{Al}$ & $\mathrm{g} \mathrm{m}^{-2}$ & $66 \pm 4 \mathrm{~b}$ & $71 \pm 4 \mathrm{ab}$ & $87 \pm 3 \mathrm{a}$ \\
$\mathrm{Fe}$ & $\mathrm{g} \mathrm{m}^{-2}$ & $1.4 \pm 0.2 \mathrm{a}$ & $1.8 \pm 0.4 \mathrm{a}$ & $1.8 \pm 0.5 \mathrm{a}$ \\
$\mathrm{Mn}$ & $\mathrm{g} \mathrm{m}^{-2}$ & $0.7 \pm 0.1 \mathrm{~b}$ & $1.8 \pm 0.3 \mathrm{a}$ & $0.6 \pm 0.2 \mathrm{~b}$ \\
$\mathrm{H}$ & $\mathrm{g} \mathrm{m}^{-2}$ & $0.2 \pm 0.0 \mathrm{a}$ & $0.2 \pm 0.0 \mathrm{a}$ & $0.2 \pm 0.1 \mathrm{a}$ \\
\hline
\end{tabular}

Means within a row followed by different letters indicate significant differences among management zones (one-way ANOVA with Tukey HSD or Kruskal-Wallis H test with multiple comparisons extension at $\mathrm{p} \leq 0.05$ ).

Bulk density measured in the top $10 \mathrm{~cm}$ of soil, whereas all the other parameters are for the $0-50 \mathrm{~cm}$ soil depth: element stocks are the sum of the sampled soil depths $(0-5 \mathrm{~cm}$, 5-10 cm, 10-30 cm and 30-50 cm) and the rest are depth-weighted averages, calculated for each replicate plot.

ECEC: effective cation exchange capacity.

There were high positive correlations between field-measured and modeled soil water matric potential (Fig. 1). The matric potential was generally lowest in the palm circle, intermediate in the inter-row, and highest in the frond-stacked area $(\mathrm{p}<0.01)$. This pattern was also reflected in the low drainage flux in the palm circle and high drainage flux in the frond-stacked area (Table 2; Fig. 2). In the palm circle, the low drainage flux had resulted from high plant transpiration and interception whereas the high drainage flux in the frond-stacked area was due to low evapotranspiration and 
runoff with the senesced frond mulch (Table 2).

Figure 1: Pearson correlation test between modeled (red line) and fieldmeasured soil water matric potential (black points) $(n=50$ field measurements over one year) for each management zone at 30- and 60-cm depths in a largescale oil palm plantation in Jambi, Indoensia.
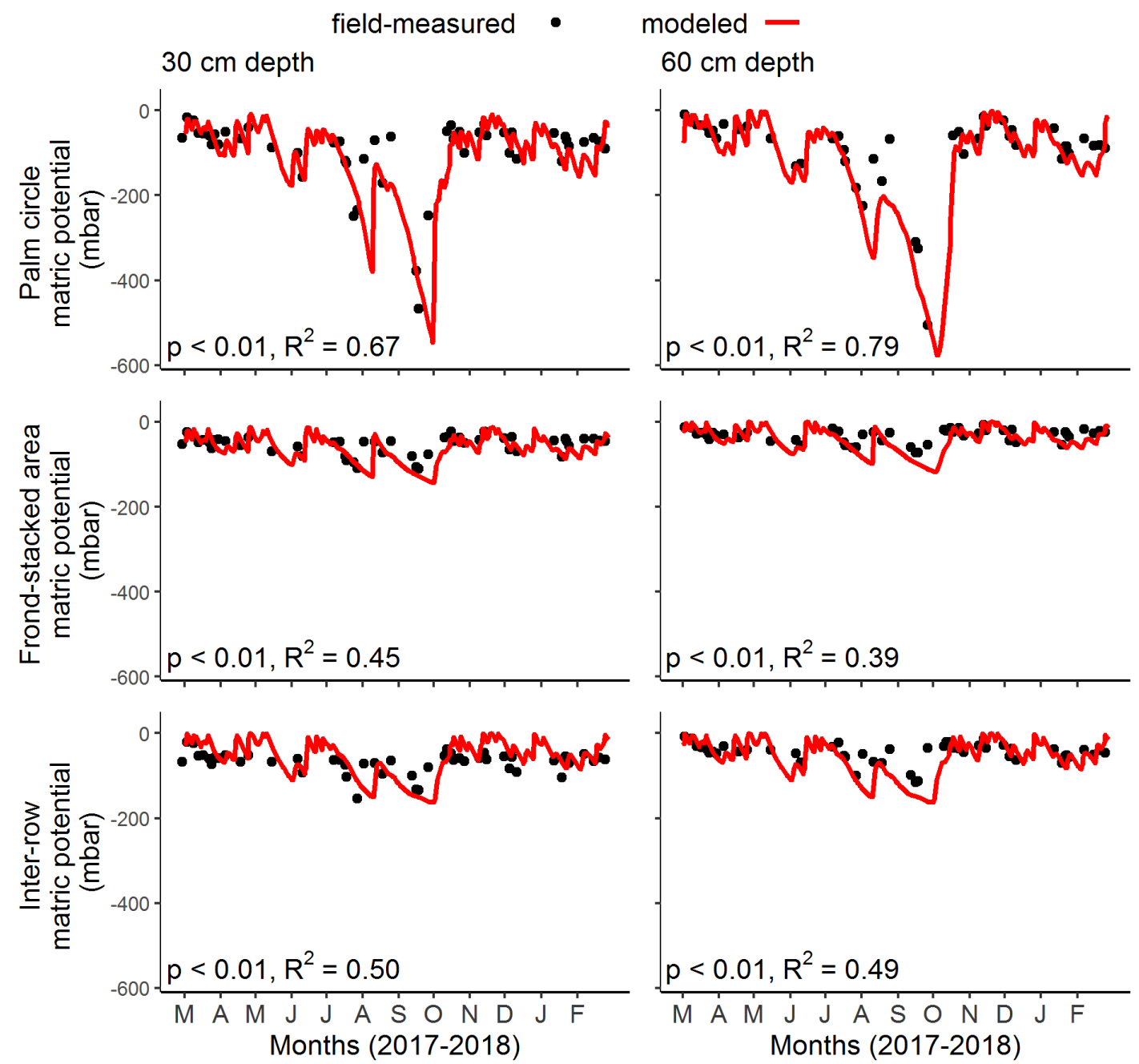

Table 2: Annual water balance simulated from March 2017 to February 2018 for each management zone in a large-scale oil palm plantation in Jambi, Indoensia.

\begin{tabular}{llll}
\hline Water flux $\left(\mathrm{mm} \mathrm{yr}^{-1}\right)$ & Palm circle & Frond-stacked area & Inter-row \\
\hline Precipitation & 2772 & 2772 & 2772 \\
Transpiration & 828 & 448 & 401 \\
Evaporation & 228 & 214 & 434 \\
Interception & 351 & 209 & 209 \\
Runoff & 338 & 0 & 216 \\
Drainage (1.5-m depth) & 556 & 1806 & 1179 \\
\hline
\end{tabular}


In ratio to annual precipitation, the calculated annual evapotranspiration was $51 \%, 31 \%$, and $38 \%$ in the palm circle, frond-stacked area, and inter-row, respectively; annual drainage fluxes at $1.5-\mathrm{m}$ depth were $20 \%$ of precipitation in the palm circle, $65 \%$ in the frond-stacked area, and $43 \%$ in the inter-row. Seasonally, the monthly drainage fluxes had two peak periods, May and November, after consecutive days of moderate rainfall, and were lowest during the end of the dry season towards the start of the wet season (Fig. 2).

Figure 2: Monthly water drainage at 1.5-m depth, simulated in each management zone, and daily rainfall from March 2017 to February 2018 in a largescale oil palm plantation in Jambi, Indoensia. The gray shaded area represent the dry season (precipitation $<140 \mathrm{~mm} \mathrm{month}^{-1}$ )

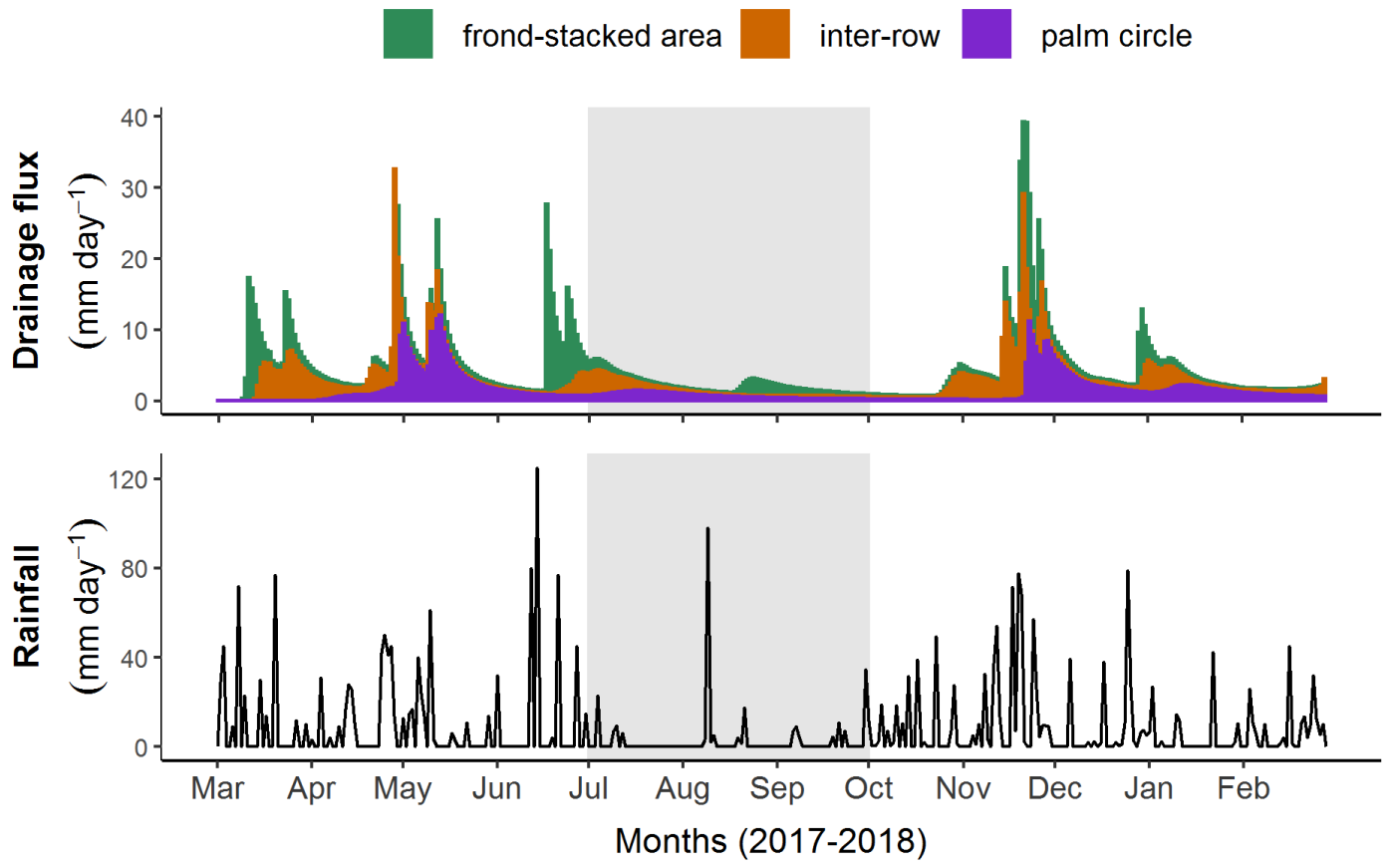

\subsubsection{Differences in leaching losses among management zones and treatments}

For element concentrations in soil-pore water at 1.5-m depth, treatment differences were exhibited clearly in the palm circle and inter-row (Fig. 3), with the herbicide treatment showing higher element concentrations than the mechanical weeding $(\mathrm{p} \leq$ 
0.02). The frond-stacked area had generally lower ionic charge concentrations compared to the other management zones (Fig. 3). The dominant cations were $\mathrm{Al}^{3+}, \mathrm{Ca}^{2+}$, $\mathrm{Mg}^{2+}, \mathrm{K}^{+}$, and $\mathrm{Na}^{+}$across experimental treatments and management zones. Among the management zones, $\mathrm{Al}^{3+}$ concentrations were highest in the inter-row, intermediate in the palm circle, and lowest in the frond-stacked area $(\mathrm{p}<0.01)$. The concentrations of $\mathrm{Ca}^{2+}$ were similar in the palm circle and frond-stacked area $(\mathrm{p}=0.42)$, and these were higher than the inter-row $(\mathrm{p}<0.01)$. The concentrations of $\mathrm{Mg}^{2+}$ and $\mathrm{K}^{+}$were higher in the palm circle than in the other two management zones $(\mathrm{p}<0.01)$. The $\mathrm{Na}^{+}$concentrations were higher in the palm circle and inter-row than in the frond-stacked area $(\mathrm{p}<0.01)$. As for dissolved $\mathrm{N}, \mathrm{NH}_{4}{ }^{+}$concentrations were lower in the frond-stacked area, followed by the palm circle, and higher in the inter-row $(\mathrm{p}=0.01)$. Across treatments, $\mathrm{NH}_{4}{ }^{+}$was $4-18 \%$ of TDN whereas DON was $1-7 \%$ of TDN. Thus, $\mathrm{NO}_{3}{ }^{-}$was the main form of dissolved $\mathrm{N}$, and this was highest in the inter-row, followed by the frond-stacked area, and lowest in the palm circle $(\mathrm{p}<0.01)$. The dominant anion was $\mathrm{Cl}^{-}$with higher concentrations in the palm circle than in the other zones $(\mathrm{p}<0.01)$. 
Figure 3: Partial cation-anion charge balance of the major solutes (with concentrations $>0.03 \mathrm{mg} \mathrm{L}^{-1}$ ) in soil water at 1.5-m depth for each experimental treatment in the different management zones in a large-scale oil palm plantation in Jambi, Indoensia.

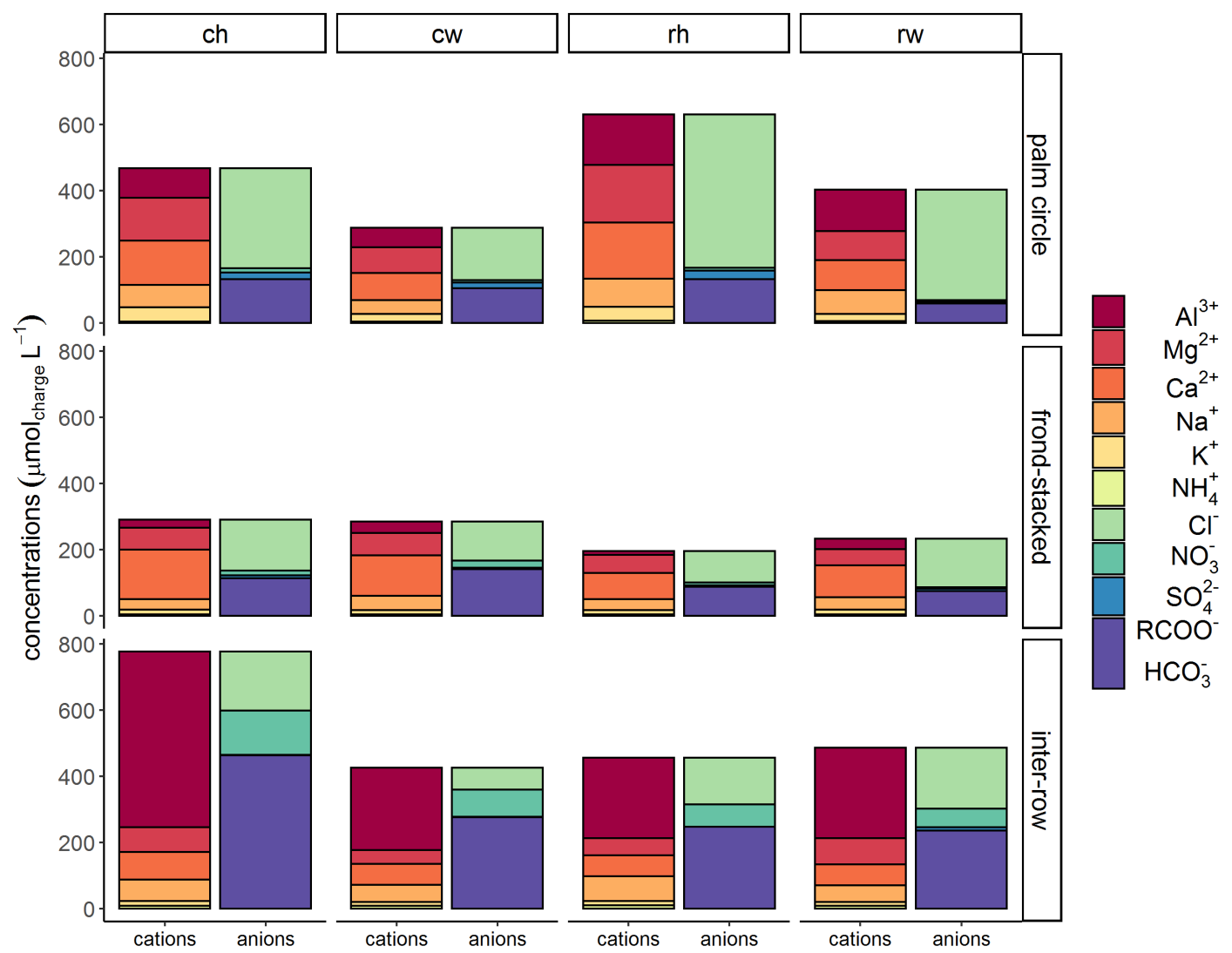

The concentrations of organic acids $\left(\mathrm{RCOO}^{-}\right)$and carbonates $\left(\mathrm{HCO}_{3}{ }^{-}\right)$are calculated as the difference between the measured cations and anions.

Treatments: $\mathrm{ch}=$ conventional fertilization-herbicide; $\mathrm{cw}=$ conventional fertilization-mechanical weeding; $r h=$ reduced fertilization-herbicide; $r w$ = reduced fertilization-mechanical weeding.

Monthly leaching fluxes showed a common pattern among the major solutes (Fig. 4): there were two peaks of leaching losses (May and November) that followed fertilizer applications, and lower leaching losses during the dry season from July to October. Leaching fluxes of $\mathrm{NO}_{3}{ }^{-}$showed similar pattern as its concentrations: higher in the inter-row, followed by the frond-stacked area, and lower in the palm circle $(\mathrm{p}<$ 0.01; Fig. 4). 
Figure 4: Monthly leaching losses at $1.5 \mathrm{~m}$ depth (mean \pm standard errors, $\mathrm{n}=4$ plots) for each management zone in a large-scale oil palm plantation in Jambi, Indoensia. Black arrows indicate fertilizer applications and the gray shaded area represents the dry season (precipitation $>140 \mathrm{~mm} \mathrm{month}^{-1}$ )
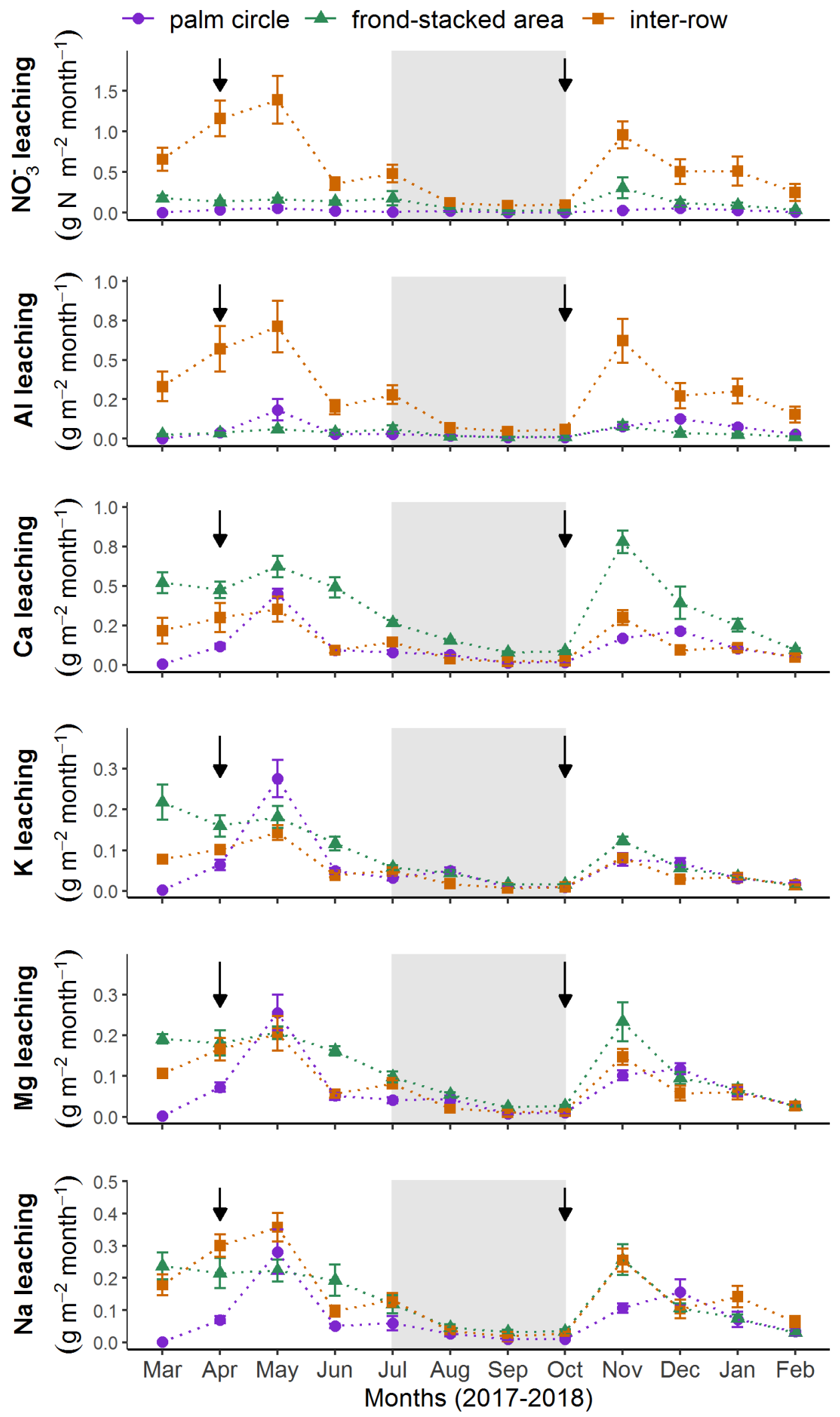
Total Al leaching fluxes were also higher in the inter-row than the other zones ( $\mathrm{p}<0.01 ;$ Fig. 4). On the other hand, although base cation concentrations were large in the palm circle (Fig. 3), the low drainage fluxes in this zone (Fig. 2; Table 2) resulted in opposite patterns of base cation leaching fluxes among management zones; $\mathrm{Ca}, \mathrm{K}$, and $\mathrm{Mg}$ were higher in the frond-stacked area than the palm circle and inter-row (all $\mathrm{p}<$ 0.01; Fig. 4). Leaching of Na was higher in both the frond-stacked area and inter-row than the palm circle ( $\mathrm{p}<0.01$; Fig. 4).

Reduced intensity of management clearly influenced nutrient leaching losses (Fig. 5; Table 3). Specifically, mechanical weeding reduced $\mathrm{NO}_{3}{ }^{-}$and cation leaching compared to herbicide weed control ( $\mathrm{p} \leq 0.03$; Fig. 5; Table 3). Leaching of $\mathrm{NO}_{3}{ }^{-}$was highest in the conventional fertilization-herbicide treatment and lowest in reduced management treatments ( $\mathrm{p} \leq 0.02$; Fig. 5). This was also reflected in the leaching fluxes of accompanying cations; specifically, total $\mathrm{Al}$ and $\mathrm{Ca}$ leaching were higher in conventional fertilization-herbicide treatment than the reduced management treatments (all $p$ $\leq$ 0.02; Fig. 5). For the other base cations, mechanical weeding clearly lowered leaching losses compared to herbicide weeding, in particular $\mathrm{K}$ and $\mathrm{Na}$ leaching in both fertilization rates and $\mathrm{Mg}$ leaching in conventional fertilization (all $\mathrm{p} \leq 0.03$; Fig. 5). 
Figure 5: Average monthly leaching losses at 1.5-m depth for each experimental treatment from March 2017 to February 2018 in a large-scale oil palm plantation in Jambi, Indoensia. Values are area-weighted averages of leaching losses in each management zone (means \pm standard errors, $\mathrm{n}=4$ plots).
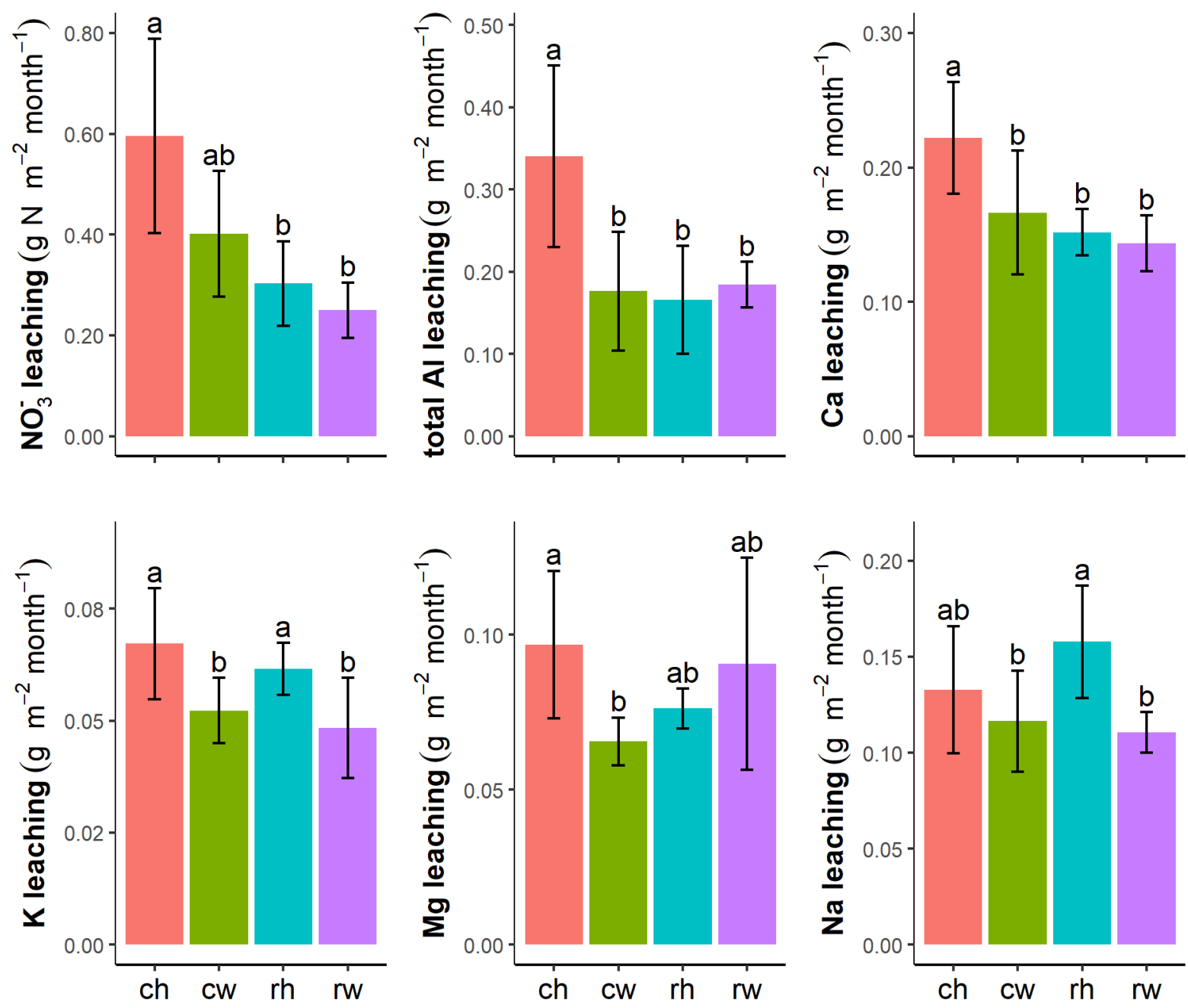

For each parameter, different letters indicate significant differences among treatments (linear-mixed effect models on monthly values followed by Tukey HSD test for multiple comparisons at $\mathrm{p} \leq 0.05$ ).

Treatments: $\mathrm{ch}=$ conventional fertilization-herbicide; $\mathrm{cw}=$ conventional fertilization-mechanical weeding; rh = reduced fertilization-herbicide; rw = reduced fertilization-mechanical weeding. 
Table 3: Annual leaching losses at 1.5-m depth for each experimental treatment from March 2017 to February 2018 in a large-scale oil palm plantation in Jambi, Indoensia. Values are area-weighted averages of leaching losses in each management zone (mean \pm standard error, $\mathrm{n}=4$ plots).

\begin{tabular}{lllll}
\hline $\begin{array}{l}\text { Element leaching } \\
\left(\mathrm{kg} \mathrm{ha}^{-1} \mathrm{yr}^{-1}\right)\end{array}$ & ch & $\mathrm{cW}$ & rh & rw \\
\hline $\mathrm{NO}_{3}{ }^{-} \mathrm{N}$ & $71.5 \pm 20.1 \mathrm{a}$ & $48.2 \pm 13.0 \mathrm{ab}$ & $36.3 \pm 20.1 \mathrm{~b}$ & $30.0 \pm 5.7 \mathrm{~b}$ \\
$\mathrm{NH}_{4}{ }^{+}-\mathrm{N}$ & $1.7 \pm 0.2 \mathrm{a}$ & $1.7 \pm 0.1 \mathrm{a}$ & $1.8 \pm 0.1 \mathrm{a}$ & $1.7 \pm 0.2 \mathrm{a}$ \\
$\mathrm{DON}$ & $0.5 \pm 0.5 \mathrm{a}$ & $0.6 \pm 0.3 \mathrm{a}$ & $0.4 \pm 0.1 \mathrm{a}$ & $0.3 \pm 0.0 \mathrm{a}$ \\
$\mathrm{TDN}$ & $73.6 \pm 20.2 \mathrm{a}$ & $50.4 \pm 13.1 \mathrm{ab}$ & $38.4 \pm 8.9 \mathrm{~b}$ & $32.0 \pm 5.8 \mathrm{~b}$ \\
$\mathrm{Ca}$ & $26.6 \pm 4.3 \mathrm{a}$ & $19.4 \pm 4.4 \mathrm{~b}$ & $18.2 \pm 1.8 \mathrm{~b}$ & $17.0 \pm 2.1 \mathrm{~b}$ \\
$\mathrm{Mg}$ & $11.6 \pm 2.5 \mathrm{a}$ & $7.7 \pm 0.8 \mathrm{~b}$ & $9.1 \pm 0.7 \mathrm{ab}$ & $10.8 \pm 3.6 \mathrm{ab}$ \\
$\mathrm{K}$ & $8.1 \pm 1.3 \mathrm{a}$ & $6.2 \pm 0.7 \mathrm{~b}$ & $8.9 \pm 0.6 \mathrm{a}$ & $5.7 \pm 1.1 \mathrm{~b}$ \\
$\mathrm{Na}$ & $15.9 \pm 3.5 \mathrm{ab}$ & $13.6 \pm 2.4 \mathrm{~b}$ & $18.9 \pm 3.1 \mathrm{a}$ & $13.1 \pm 1.2 \mathrm{~b}$ \\
$\mathrm{Mn}$ & $0.3 \pm 0.1 \mathrm{a}$ & $0.2 \pm 0.0 \mathrm{~b}$ & $0.2 \pm 0.0 \mathrm{bc}$ & $0.1 \pm 0.0 \mathrm{c}$ \\
Total Al & $40.8 \pm 11.5 \mathrm{a}$ & $20.8 \pm 7.6 \mathrm{~b}$ & $19.9 \pm 6.8 \mathrm{~b}$ & $21.8 \pm 3.1 \mathrm{~b}$ \\
Total S & $2.4 \pm 0.5 \mathrm{a}$ & $1.8 \pm 0.4 \mathrm{a}$ & $2.1 \pm 0.6 \mathrm{a}$ & $4.9 \pm 3.3 \mathrm{a}$ \\
Total Fe & $0.2 \pm 0.0 \mathrm{a}$ & $0.5 \pm 0.3 \mathrm{a}$ & $0.2 \pm 0.0 \mathrm{a}$ & $0.5 \pm 0.3 \mathrm{a}$ \\
Total P & $0.0 \pm 0.0 \mathrm{a}$ & $0.1 \pm 0.0 \mathrm{a}$ & $0.0 \pm 0.0 \mathrm{a}$ & $0.0 \pm 0.0 \mathrm{a}$ \\
$\mathrm{Cl}$ & $79.7 \pm 15.8 \mathrm{a}$ & $36.9 \pm 8.3 \mathrm{~b}$ & $67.7 \pm 8.7 \mathrm{a}$ & $78.3 \pm 7.5 \mathrm{a}$ \\
\hline
\end{tabular}

Means followed by different letters indicate differences among experimental treatments (linear-mixed effect models on monthly values followed by Tukey HSD test for multiple comparisons at $\mathrm{p} \leq 0.05$ ).

Treatments: $\mathrm{ch}=$ conventional fertilization-herbicide; $\mathrm{cw}=$ conventional fertilization-mechanical weeding; $r$ = reduced fertilization-herbicide; $\mathrm{rw}=$ reduced fertilization-mechanical weeding; rw = reduced fertilization-mechanical weeding; $\mathrm{DON}=$ dissolved organic $\mathrm{N} ; \mathrm{TDN}=$ total dissolved $\mathrm{N}$.

\subsubsection{Annual leaching losses and nutrient retention efficiency}

In proportion to the applied fertilizer, annual leaching losses of TDN (Table 3) were $28 \%$ of the applied $\mathrm{N}$ in the herbicide treatment for both conventional and reduced fertilization rates, $24 \%$ in the mechanical weeding with conventional fertilization, and only $19 \%$ in the mechanical weeding with reduced fertilization. The annual leaching of $\mathrm{K}$ (Table 3) was $4 \%$ of the applied $\mathrm{K}$ fertilizer in the herbicide treatment and 3\% in the mechanical weeding for both fertilization rates. In this highly weathered Acrisol soils with high capacity for P fixation by $\mathrm{Fe}$ and $\mathrm{Al}$ (hydr)oxides, there was no leaching 
of dissolved P (Table 3).

Both $\mathrm{N}$ and base cation retention efficiencies were generally lower in the interrow compared to the other management zones ( $\mathrm{p} \leq 0.03)$, except for reduced fertilization-mechanical weeding where there were no differences among management zones (Table 4). The area-weighted average $\mathrm{N}$ retention efficiency was comparable among experimental treatments $(\mathrm{p}=0.89)$ but there was a trend of increasing efficiency with decreasing management intensity (Table 4). Base cation retention efficiency showed clear differences among experimental treatments for each management zones: in the palm circle, it was highest in mechanical weeding and lowest in the herbicide treatment $(\mathrm{p}=0.04)$; in the frond-staked area and inter-row, it was lowest in the most intensive management treatment (conventional fertilization-herbicide) and highest in either mechanical weeding or reduced fertilization ( $\mathrm{p} \leq 0.05$; Table 4$)$. The area-weighted average base cation retention efficiency was also clearly influenced by weeding method, being lowest in herbicide treatment and highest in mechanical weeding both with conventional fertilization $(p=0.03$; Table 4$)$. 
Table 4: $\mathrm{N}$ and base cation retention efficiencies in the soil for each management zone and experimental treatment (means \pm standard error, $\mathrm{n}=4$ plots) in a largescale oil palm plantation in Jambi, Indoensia.

\begin{tabular}{|c|c|c|c|c|}
\hline \multicolumn{5}{|c|}{$\mathrm{N}$ retention efficiency $\left(\mathrm{mg} \mathrm{N} \mathrm{m}^{-2} \mathrm{~d}^{-1} / \mathrm{mg} \mathrm{N} \mathrm{m}^{-2} \mathrm{~d}^{-1}\right)$} \\
\hline & $\mathrm{ch}$ & $\mathrm{cW}$ & $\mathrm{rh}$ & rw \\
\hline \multicolumn{5}{|l|}{ Palm } \\
\hline circle & $0.987 \pm 0.002 \mathrm{aA}$ & $0.982 \pm 0.007 \mathrm{aAB}$ & $0.986 \pm 0.003 \mathrm{aAB}$ & $0.997 \pm 0.000 \mathrm{aA}$ \\
\hline Frond- & & & & \\
\hline $\begin{array}{l}\text { stacked } \\
\text { Inter- }\end{array}$ & $0.984 \pm 0.004 \mathrm{aA}$ & $0.989 \pm 0.004 \mathrm{aA}$ & $0.993 \pm 0.001 \mathrm{aA}$ & $0.987 \pm 0.002 \mathrm{aA}$ \\
\hline row & $0.877 \pm 0.025 \mathrm{aB}$ & $0.870 \pm 0.022 \mathrm{aB}$ & $0.900 \pm 0.018 \mathrm{aB}$ & $0.906 \pm 0.039 \mathrm{aA}$ \\
\hline $\begin{array}{l}\text { Weighted- } \\
\text { average }\end{array}$ & $0.925 \pm 0.022 \mathrm{a}$ & $0.934 \pm 0.020 \mathrm{a}$ & $0.945 \pm 0.012 \mathrm{a}$ & $0.946 \pm 0.018 a$ \\
\hline \multicolumn{5}{|c|}{ Base cation retention efficiency $\left(\mathrm{mol}_{\mathrm{C}} \mathrm{m}^{-2} \mathrm{yr}^{-1} / \mathrm{mol}_{\mathrm{c}} \mathrm{m}^{-2} \mathrm{yr}^{-1}\right)$} \\
\hline & $\mathrm{ch}$ & $\mathrm{cW}$ & $\mathrm{rh}$ & rw \\
\hline $\begin{array}{l}\text { Palm } \\
\text { circle }\end{array}$ & $0.967 \pm 0.008 \mathrm{abA}$ & $0.982 \pm 0.002 \mathrm{aA}$ & $0.937 \pm 0.013 \mathrm{bA}$ & $0.974 \pm 0.010 \mathrm{abA}$ \\
\hline $\begin{array}{l}\text { Frond- } \\
\text { stacked } \\
\text { Inter- }\end{array}$ & $0.884 \pm 0.013 \mathrm{bA}$ & $0.950 \pm 0.004 \mathrm{aA}$ & $0.960 \pm 0.002 \mathrm{aA}$ & $0.928 \pm 0.016 \mathrm{abA}$ \\
\hline row & $0.588 \pm 0.086 \mathrm{bB}$ & $0.875 \pm 0.022 \mathrm{aB}$ & $0.704 \pm 0.048 \mathrm{abB}$ & $0.822 \pm 0.063 \mathrm{abA}$ \\
\hline $\begin{array}{l}\text { Weighted- } \\
\text { average }\end{array}$ & $0.876 \pm 0.009 b$ & $0.945 \pm 0.007 \mathrm{a}$ & $0.902 \pm 0.019 \mathrm{ab}$ & $0.934 \pm 0.012 \mathrm{ab}$ \\
\hline
\end{tabular}

Means followed by different lowercase letters indicate differences among experimental treatments for each management zone, whereas different uppercase letters indicate differences among management zones for each experimental treatment (one-way ANOVA with Tukey HSD or Kruskal-Wallis H test with multiple comparisons extension at $\mathrm{p} \leq 0.05$ );

Weighted-average is based on the areal coverage of each management zone: $18 \%$ for palm circle, $15 \%$ for frond-stacked area, and $67 \%$ for inter-row. See section 2.4 for calculations of $\mathrm{N}$ and base cation retention efficiency.

Treatments: $\mathrm{ch}=$ conventional fertilization-herbicide; $\mathrm{cw}=$ conventional fertilization-mechanical weeding; $r h=$ reduced fertilization-herbicide; $r w=$ reduced fertilization-mechanical weeding. 


\subsection{Discussion}

\subsubsection{Water model and temporal pattern of nutrient leaching losses}

To our knowledge, this study is the first attempt to model drainage fluxes from the different management zones of an oil palm plantation, making our comparisons with literature values limited. Our modeled annual transpiration rate in the palm circle (Table 2) was remarkably similar to the values estimated with the same Penman-Monteith method (827-829 mm yr ${ }^{-1}$, Meijide et al. 2017, Röll et al. 2019), and our average daily transpiration rate $\left(2.3 \mathrm{~mm} \mathrm{~d}^{-1}\right)$ was within the range of that measured with dronebased photogrammetry ( $3 \pm 1 \mathrm{~mm} \mathrm{~d}^{-1}$, Ahongshangbam et al. 2019), all in the same oil palm plantation. Also, the modeled annual runoff in the palm circle and inter-row (Table 2) was within the range of runoff estimates in oil palm plantations in Jambi province (10-20\% of rainfall, Tarigan et al. 2016) and in Papua New Guinea (1.4-6\% of rainfall, Banabas et al. 2008b). Considering the areal proportions of the three management zones, the weighted-average drainage flux $\left(1161 \mathrm{~mm} \mathrm{yr}^{-1}\right)$ was lower than that estimated for smallholder oil palm plantations near our study site (1614 mm drainage flux with $3418 \mathrm{~mm}$ precipitation measured in 2013, Kurniawan et al. 2018), although their ratios to annual precipitation were comparable. Aside from the difference in precipitation during our study period compared to the relatively wet year of 2013, evapotranspiration rate is higher in large-scale than smallholder oil palm plantations in our study area (Röll et al. 2019), which would lead to lower drainage flux in large-scale plantation. Moreover, in the frond-stacked area, enhanced porosity from organic matter that facilitates water infiltration (Moradi et al. 2015), as indirectly indicated by its low soil bulk density (Table 1), combined with low evapotranspiration and run-off, resulted in large drainage flux (Table 2). This suggests that piling senesced fronds may amend groundwater recharge, which could moderate discharge fluctuations in 
water catchments of oil palm converted areas (Tarigan et al. 2020). Based on these comparisons with literature values and on the good agreement between modeled and measured soil water matric potential (Fig. 1), we conclude that our modeled drainage fluxes were reliable.

The temporal peaks of nutrient leaching fluxes (May and November; Fig. 4) had resulted from the combined effect of high drainage flux and fertilizer application. The high drainage fluxes in May and November (Fig. 2) might have stimulated the downward transport of elements and decreased their residence time in the soil, and thus their adsorption onto the soil exchange sites (Lohse and Matson 2005). These high water fluxes usually dilute the element concentrations in the soil-pore water; however, high concentrations were maintained because of fertilizer and lime applications in the same periods, resulting in parallel peaks of drainage and leaching fluxes (Figs. 2 and 4). The high $\mathrm{NO}_{3}{ }^{-}$leaching following urea-N fertilization (Fig. 4) suggests increased nitrification (Silver et al. 2005), fast $\mathrm{NO}_{3}{ }^{-}$transport through the soil column, and reduced anion adsorbtion capacity, which otherwise would have delayed anion leaching (Wong et al. 1990). The latter was possibly aggravated by the additional $\mathrm{Cl}^{-}$from fertilization with $\mathrm{KCl}$ (Fig. 3), which could saturate the soil anion exchange sites, particularly at this mature plantation with already 16-20 years of high fertilization rates. Large $\mathrm{NO}_{3}{ }^{-}$leaching is always accompanied by large leaching of buffering cations (Dubos et al. 2017, Kurniawan et al. 2018), resulting in their similar temporal patterns (Fig. 4). These findings showed that fertilization should be avoided during periods of high drainage fluxes. Generally, the high drainage was a consequence of a protracted period of moderate rainfall (Fig. 2). Prediction of periods of high precipitation and drainage will further be confounded by climate change, which is widening the range between wet and dry seasons and increasing the uncertainties in rainfall intensity and distribution (Chou et al. 2013, Feng et al. 2013). Fertilization during the dry period is also not advisable given the high volatilization of applied urea even in acidic soil as this is 
always accompanied by liming (Goh et al. 2003, Pardon et al. 2016) and the low palm uptake during the dry season (Corley and Tinker 2016). Thus, reduction of fertilization rates, e.g. at compensatory level equal to harvest export, seems a viable option to reduce leaching losses without sacrificing production. One other option is the use of organic amendments and slow-release fertilizers, which have been shown to reduce $\mathrm{N}$ leaching in tropical cropping systems (Nyamangara et al. 2003, Mohanty et al. 2018, Steiner et al. 2008) and to improve soil fertility in oil palm plantations (Comte et al. 2013, Boafo et al. 2020), as was also evident with mulching of senesced oil palm fronds (i.e. high SOC, total N, ECEC and base saturation in the frond-stacked area; Table 1).

\subsubsection{Leaching losses in the different management zones}

Contrary to our first hypothesis, leaching losses were generally higher in the inter-row, especially for mineral $\mathrm{N}$ (largely $\mathrm{NO}_{3}^{-}$; Fig. 3), compared to the other zones, whereas the palm circle had the lowest leaching (Fig. 4). This strikingly large mineral $\mathrm{N}$ leaching losses in the inter-row were surprising given that this area did not receive direct fertilizer inputs (see section 2.1). This result suggests that mineral $\mathrm{N}$ was transported from the directly fertilized palm circle to the inter-row via surface and subsurface lateral flow as these two zones were just $3 \mathrm{~m}$ apart (Fig. S1). Surface transport of mineral $\mathrm{N}$ was probably a minor process at our site because of the low runoff (Table 2); in an oil palm plantation in Papua New Guinea, the loss of $\mathrm{N}$ fertilizer via surface runoff is only $0.3-2.2 \mathrm{~kg} \mathrm{~N} \mathrm{ha}^{-1} \mathrm{yr}^{-1}$ (Banabas et al. 2008b). Mineral $\mathrm{N}$ was probably predominantly transported to the inter-row via subsurface lateral flow. Acrisol soils are characterized by clay translocation from upper to lower depths that could create an impeding layer conducive to lateral water flow (Elsenbeer 2001). Indeed, the clay contents of the Acrisol soils at our study area increase with depth, and soil bulk density is highest at 100-150-cm depth (Allen et al. 2016). In addition, the palm roots spreading from the palm circle to the inter-row may create channels for subsurface lateral flow 
of dissolved ions like $\mathrm{NO}_{3}^{-}$( $\mathrm{Li}$ and Ghodrati 1994). Higher mineral $\mathrm{N}$ leaching in the inter-row than palm circle was also observed in Brazil and it was attributed to lower root density and higher $\mathrm{N}$ mineralization at increasing distance from the palm's trunk (Schroth et al. 2000). Hence, a combination of lower root uptake, higher N mineralization, and subsurface lateral transport (particularly for $\mathrm{NO}_{3}^{-}$) may all have contributed to higher mineral $\mathrm{N}$ leaching losses in the inter-row than the palm circle. The main accompanying cation for $\mathrm{NO}_{3}{ }^{-}$leaching in the inter-rows was $\mathrm{Al}^{3+}$ (Figs. 3 and 4), as this zone's soil $\mathrm{pH}$ (Table 1) was within the Al-buffering range ( $\mathrm{pH} 3-5$ van Breemen et al. 1983), having no direct lime application and thus low base saturation (Table 1). Our findings showed that if leaching is measured only within the palm circle, this largely underestimates mineral $\mathrm{N}$ and $\mathrm{Al}$ leaching losses.

The palm circle had relatively low $\mathrm{N}$ leaching losses (Figs. 3 and 4) despite the direct application of fertilizer. This was probably due to the large root density in this zone that facilitates an efficient nutrient uptake (Edy et al. 2020, Nelson et al. 2006). Hence, the dominant anion in soil-pore water in the palm circle was $\mathrm{Cl}^{-}$(Fig. 3), enhanced by the applied $\mathrm{KCl}$ fertilizer, which was accompanied by high base cation concentrations relative to dissolved $\mathrm{Al}$ (Fig. 3). The former was due to the applied micromag fertilizer and dolomite (section 2.1), which increased $\mathrm{pH}$ and exchangeable bases and rendered $\mathrm{Al}$ in insoluble form (i.e. lower exchangeable Al, Table 1, Schlesinger and Bernhardt 2013). Despite their high concentrations, the leaching fluxes of base cations in the palm circle (Fig. 4) were constrained by the low water drainage flux due to high evapotranspiration (Table 2).

The frond-stacked area was at the same distance from the palm circle as the inter-row (Fig. S1) but had substantially lower mineral $\mathrm{N}$ leaching losses (Figs. 3 and 4). Decomposition of nutrient-rich fronds (Kotowska et al. 2016) resulted in high SOC and N stocks (Table 1), which can support large microbial biomass in this zone (Haron et al. 1998). Thus, the low mineral $\mathrm{N}$ leaching in the frond-stacked area may 
be attributed to immobilization of mineral $\mathrm{N}$ by large microbial biomass, converting mobile $\mathrm{NO}_{3}{ }^{-}$to less mobile organic $\mathrm{N}$ (e.g. Corre et al. 2010). In addition, it could be possible that palm root uptake of nutrients (including mineral N) was higher in the frond-stacked area compared to the inter-row as roots proliferate in nutrient-rich zones (Table 1, Hodge 2004). This is supported by studies that showed higher root density and higher water uptake under the frond piles compared to the inter-row (Rüegg et al. 2019, Nelson et al. 2006). The high ECEC, base saturation and pH in frond-stacked area (Table 1), despite having no direct lime application, were due to the release of nutrients from decomposition of frond litter, which contain high levels of base cations (Kotowska et al. 2016). Thus, although leaching of base cations were larger in the frond-stacked area than in the inter-row (Fig. 4), these losses merely mirrored their high exchangeable levels (Table 1). Finally, the leaching of $\mathrm{Al}$ was low in the frond-stacked area (Figs. 3 and 4) because $\mathrm{Al}$ becomes insoluble as $\mathrm{pH}$ increased (i.e. lower exchangeable $\mathrm{Al}$, Table 1). Altogether, these results highlighted the benefits of piling senesced fronds onto the soil to reduce leaching of mineral $\mathrm{N}$ and $\mathrm{Al}$, which otherwise can potentially diminish ground water quality, and to amend soil fertility (Table 1). Oil palm plantations in other areas (e.g. Borneo, Rahman et al. 2018) were reported to practice piling of senesced fronds on every inter-row, which we did not observed in our study region as that is claimed to hinder access to palms during harvest; nonetheless, our findings implied that increase in the frond-stacked area can contribute to sustainable management practices of oil palm plantations.

\subsubsection{Leaching losses under different intensity of management}

There was a general reduction of leaching fluxes with reduced management intensity (Fig. 5, Table 3). In line with our second hypothesis, the weeding methods clearly influenced leaching losses with a common pattern of lower leaching fluxes in mechanical weeding than herbicide treatment (Fig. 5, Table 3). Mechanical weeding was associated 
with more ground vegetation cover (Darras et al. 2019) and higher nutrient retention efficiency than herbicide weeding (Table 4), suggesting that faster regrowth of understory vegetation by mechanical weeding have additionally contributed to the uptake of nutrients and thus reducing leaching losses. This is in line with some studies in temperate forests and a cedar plantation, which showed that understory vegetation can take up excess $\mathrm{NO}_{3}{ }^{-}$in the soil (Olsson and Falkengren-Grerup 2003) and reduce $\mathrm{NO}_{3}{ }^{-}$ leaching and the mobilization of Ca and Mg (Baba et al. 2011, Fukuzawa et al. 2006). Enhanced understory vegetation in oil palm plantations may also positively impact biodiversity by increasing plant species richness and soil macrofauna diversity and abundance (Luke et al. 2019, Ashton-Butt et al. 2018), which may facilitate uptake and recycling of nutrients. The increase of soil macrofauna might have contributed to lower leaching of $\mathrm{Na}$ with mechanical weeding (Fig. 5), since herbivores and decomposers take up a large amount of $\mathrm{Na}$ (Kaspari et al. 2009). In addition, the use of glyphosate is associated with possible health risks to workers and the environment (van Bruggen et al. 2018); also, the economic gross margin (i.e. revenues minus costs) is comparable between mechanical weeding and herbicide treatment because of needed labor for periodic mechanical cutting of resistant ground vegetation in oil palm plantations with herbicide weeding (Darras et al. 2019, Pahan 2010). Altogether, these results advocate for the higher sustainability of mechanical weeding over herbicide application.

The reduction of $\mathrm{N}$ fertilization rates decreased $\mathrm{NO}_{3}{ }^{-}$leaching, supporting our third hypothesis. Comparing conventional and reduced fertilization rates, there were no differences in total $\mathrm{N}$ stocks (section 3.1), mineral $\mathrm{N}$ levels (Darras et al. 2019), $\mathrm{N}$ retention efficiency (Table 4) and oil palm yield (Darras et al. 2019), suggesting that excess $\mathrm{N}$ (above harvest export, section 2.1) from high $\mathrm{N}$ fertilization was largely lost through leaching (Table 3). The decreased Al and Ca leaching with reduced fertilization can be attributed to the lowered $\mathrm{NO}_{3}{ }^{-}$leaching, since these were the accompanying cations (Figs. 4 and 5). Also, a reduction of Ca leaching could have resulted from the 
lower application rate of triple superphosphate fertilizer, which contains $16 \%$ of Ca. The reduced $\mathrm{K}$ fertilization had no effect on $\mathrm{K}$ leaching (Fig. 5) because $\mathrm{K}$ fertilization rate was only reduced by $15 \%$ of the conventional rate due to high $\mathrm{K}$ requirements of oil palm fruits (section 2.1). We conclude that this mature (16-20 years old) plantation with conventional management was overly fertilized for $\mathrm{N}$, and that a reduction in $\mathrm{N}$ fertilization rate may be included in the Indonesian program for precision farming (Ministry of Agriculture of Indonesia 2016) to reduce environmental footprint of oil palm production.

Comparing the $\mathrm{N}$ leaching losses in the studied plantation with other fertilized tropical plantations (Table S2), our plantation had higher N leaching than other largescale oil palm plantations on similar soils with comparable fertilization rates (Omoti et al. 1983, Tung et al. 2009). However, in these studies the leaching losses were measured in the palm circle (Omoti et al. 1983) or the sampling location was not specified (Tung et al. 2009), such that $\mathrm{N}$ leaching may be underestimated as our results showed the high contribution of the inter-row to leaching losses (Figs. 3 and 4). The $\mathrm{N}$ leaching fluxes in our plantation were also higher than in smallholder oil palm plantations in the same area, which typically had much lower fertilization rates (Kurniawan et al. 2018). On the other hand, our plantation had lower $\mathrm{N}$ leaching losses than an oil palm plantation and coffee agroforestry systems on volcanic soils (Banabas et al. 2008b, Cannavo et al. 2013, Tully et al. 2012), which have high inherent nutrient contents, highly porous soils and high infiltration rates. The $\mathrm{N}$ leaching losses from our plantation were also lower than in banana plantations, characterized by very high fertilization rates (Wakelin et al. 2011, Armour et al. 2013).

The nutrients leached at 1.5-m depth should be considered lost from uptake of oil palm roots, as majority of the root mass and the highest root density are in the top 0.5-m depth (Nelson et al. 2006, Schroth et al. 2000, Kurniawan et al. 2018). The high leaching fluxes of $\mathrm{NO}_{3}{ }^{-}$and $\mathrm{Al}$ implied a risk of groundwater pollution. During 
the high drainage fluxes following fertilization, $\mathrm{NO}_{3}{ }^{-}$concentrations in soil-pore water reached to $20-40 \mathrm{mg} \mathrm{L}^{-1}$ in the inter-row (covering $67 \%$ of the plantation area), which was close to the $50 \mathrm{mg} \mathrm{L}^{-1}$ limit for drinking water (WHO 2011), and $\mathrm{Al}$ concentrations in soil-pore water exceeded the limit of $0.2 \mathrm{mg} \mathrm{L}^{-1}$ in $60 \%$ of the samples. Nevertheless, before reaching to streams and rivers, these $\mathrm{NO}_{3}{ }^{-}$and $\mathrm{Al}$ concentrations can be diluted by surface flow and retained in the soil along flow paths: $\mathrm{NO}_{3}{ }^{-}$can be temporarily adsorbed in the deeper layers of highly weathered soils by its inherently high anion exchange capacity (Harmand et al. 2010, Jankowski et al. 2018) and can be consumed by denitrification (Wakelin et al. 2011). Riparian buffers can mitigate the transport of these agricultural pollutants to streams (Luke et al. 2017, Chellaiah and Yule 2018). Restoring riparian buffers in former forests converted to oil palm plantations have been listed as one sustainability criteria, endorsed by the Roundtable for Sustainable Palm Oil (RSPO) association, and may provide additional regulation services (Woodham et al. 2019).

In conclusion, our findings show that nutrient leaching losses in an oil palm plantation differed among management zones, as a result of fertilization, liming, mulching and of different drainage fluxes. The reduction of management intensity, i.e. mechanical weeding with reduced fertilization rates, was effective in reducing nutrient leaching losses without reduction in yield at least during the first two years of this experiment (Darras et al., 2019). Long-term investigation of this management experiment is important to get a reliable response of yield and a holistic economic analysis, including valuation of regulation services. Greenhouse gas emissions should also be quantified, as another important parameter of environmental footprint of oil palm production. Our findings and these further investigations should be incorporated into science-based policy recommendations such as those endorsed by the RSPO. 


\section{Acknowledgements}

This study was part of the project A05 in the CRC990-EFForTS, funded by the German Research Foundation (DFG, Project ID: 192626868 - SFB 990). We acknowledge the collaborations with PTPN VI plantation, Kevin Darras, and project Z01, for the implementation and maintenance of this field experiment. We thank Christian Stiegler, with project A03, for the climate data, and Eckart Priesack for the Expert-N water submodel. We especially thank our field and laboratory assistants for their valuable dedications in all field and laboratory activities. This research was conducted under the research permit of Ministry of Research and Technology of Indonesia, 539351/SIP/FRP/E5/Dit.KI/X/2016.

\section{Declaration of author contribution}

GF performed the experiments, analysed the data and wrote the manuscript in consultation with MDC. EV and MDC conceived and planned the experiment. XD helped carry out the water model simulations. AT aided in field activities organization and granting collaborations agreements. All authors contributed to the final version of the manuscript. 


\subsection{Supplementary material}

Figure S1: Lysimeter locations at each treatment plot, with two subplots (blue rectangles) that each included the three management zones (blue crosses): (1) lysimeters in the palm circle were at $1 \mathrm{~m}$ from the palm trunk, (2) in the frondstacked area, at about $4 \mathrm{~m}$ from the palm trunk, and (3) in the inter-row, at approximately $4 \mathrm{~m}$ from the palm trunk
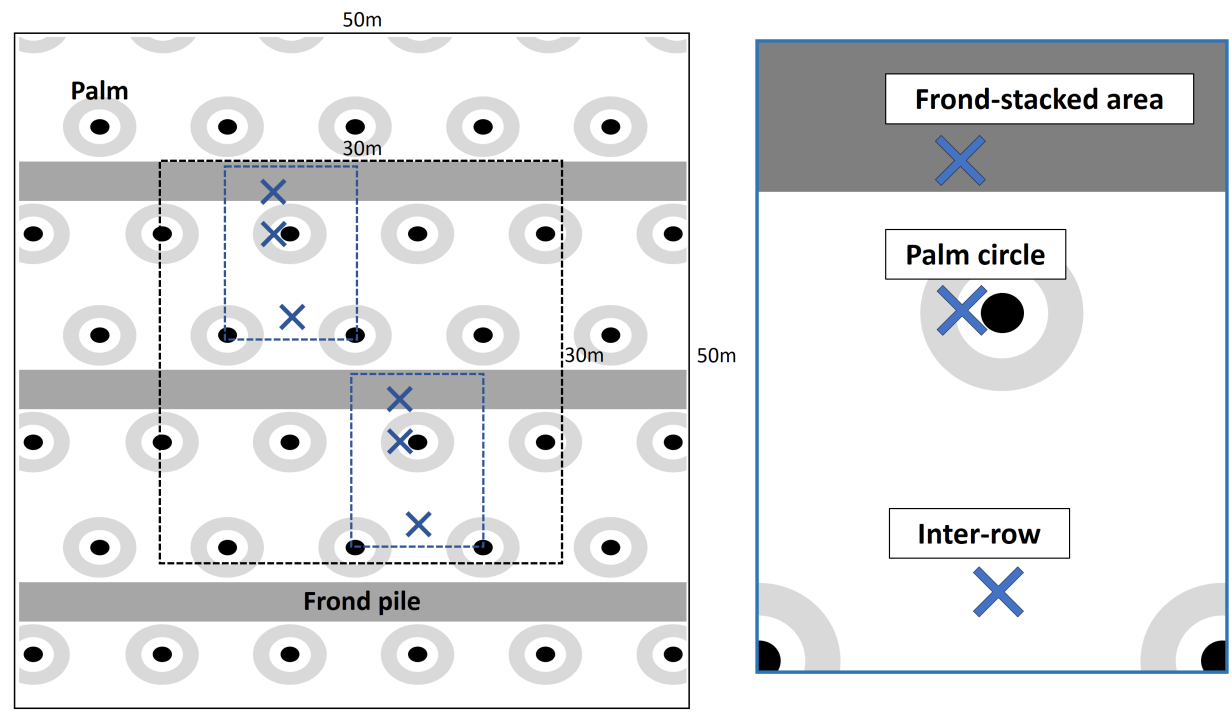

Table S1: Gross $\mathrm{N}$ mineralization rates (means $\pm \mathrm{SE}, \mathrm{n}=4$ plots) in the top5 -cm soil depth for each treatment and management zone in a large-scale oil palm plantation in Jambi, Indonesia. Data from Chapter 2.

\begin{tabular}{|c|c|c|c|c|}
\hline \multicolumn{5}{|c|}{ Gross $\mathrm{N}$ mineralization $\left(\mathrm{mg} \mathrm{N} \mathrm{m}^{-2} \mathrm{~d}^{-1}\right)$} \\
\hline & ch & $\mathrm{cW}$ & rh & rw \\
\hline Palm circle & $2.2 \pm 0.6$ & $1.9 \pm 0.4$ & $1.8 \pm 0.6$ & $3.4 \pm 0.2$ \\
\hline Frond-stacked area & $22.4 \pm 3.3$ & $32.5 \pm 8.0$ & $22.4 \pm 7.2$ & $16.6 \pm 5.2$ \\
\hline Inter-row & $4.8 \pm 1.1$ & $4.0 \pm 0.6$ & $3.8 \pm 0.8$ & $4.4 \pm 0.9$ \\
\hline
\end{tabular}

Treatments: $\mathrm{ch}=$ conventional fertilization-herbicide; $\mathrm{cw}=$ conventional fertilization-mechanical weeding; rh = reduced fertilization-herbicide; rw = reduced fertilization-mechanical weeding. 


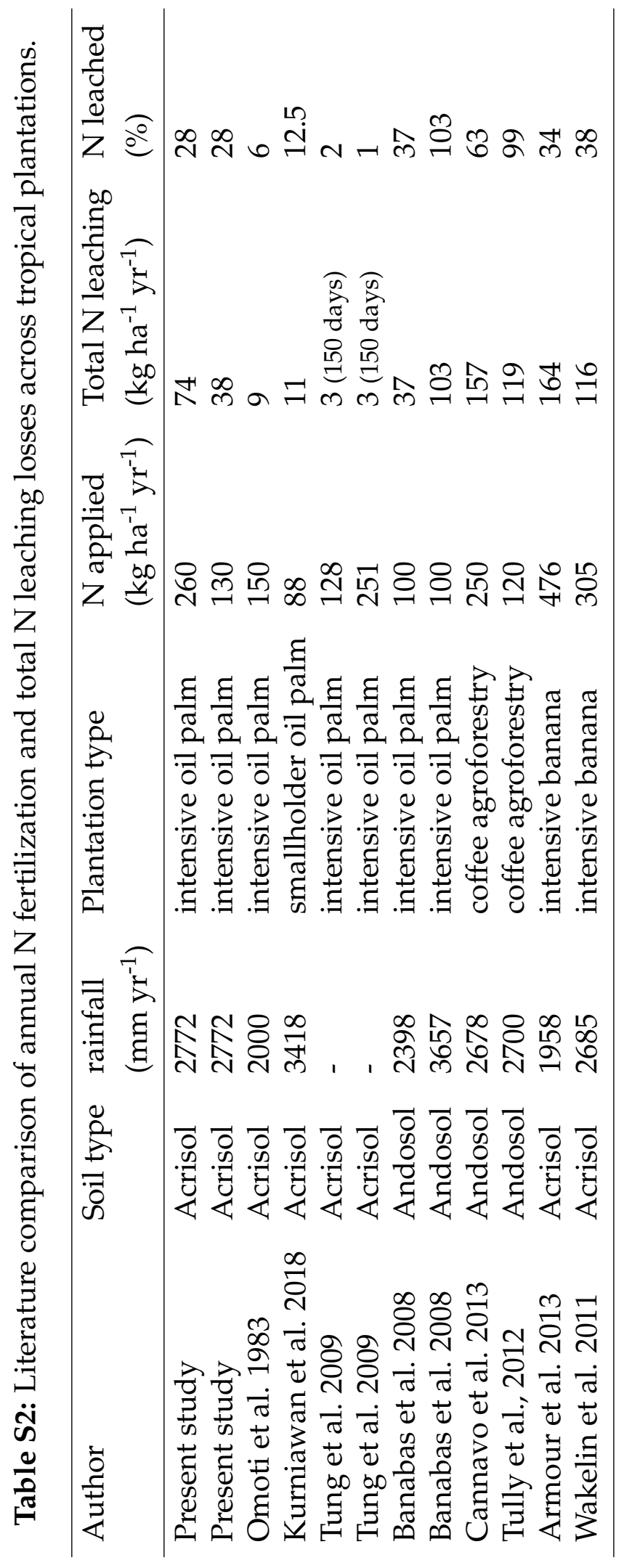




\section{References}

- Ahongshangbam J, Khokthong W, Ellsäßer F, Hendrayanto H, Hölscher D, Röll A (2019) Drone-based photogrammetry-derived crown metrics for predicting tree and oil palm water use. Ecohydrology 12(6):1-18. doi:10.1002/eco.2115

- Allen K, Corre MD, Kurniawan S, Utami SR, Veldkamp E (2016) Spatial variability surpasses land-use change effects on soil biochemical properties of converted lowland landscapes in Sumatra, Indonesia. Geoderma 284:42-50.

doi:10.1016/j.geoderma.2016.08.010

- Allen K, Corre MD, Tjoa A, Veldkamp E (2015) Soil nitrogen-cycling responses to conversion of lowland forests to oil palm and rubber plantations in Sumatra, Indonesia. PloS One 10(7):e0133325. doi:10.1371/journal.pone.0133325

- Allen RG (1998) Crop evapotranspiration. Guidelines for computing crop water requirements. FAO irrigation and drainage paper, vol 56, Rome

- Armour JD, Nelson PN, Daniells JW, Rasiah V, Inman-Bamber NG (2013) Nitrogen leaching from the root zone of sugarcane and bananas in the humid tropics of Australia. Agriculture, Ecosystems \& Environment 180:68-78.

doi:10.1016/j.agee.2012.05.007

- Ashton-Butt A, Aryawan AAK, Hood ASC, Naim M, Purnomo D, Suhardi, Wahyuningsih R, Willcock S, Poppy GM, Caliman J-P, Turner EC, Foster WA, Peh KSH, Snaddon JL (2018) Understory vegetation in oil palm plantations benefits soil biodiversity and decomposition rates. Frontiers in Forests and Global Change 1:1-13. doi:10.3389/ffgc.2018.00010

- Asner GP, Powell GVN, Mascaro J, Knapp DE, Clark JK, Jacobson J,

Kennedy-Bowdoin T, Balaji A, Paez-Acosta G, Victoria E, Secada L, Valqui M, Hughes FR (2010) High-resolution forest carbon stocks and emissions in the Amazon. PNAS 107(38):16738-16742. doi:10.1073/pnas.1004875107

- Baba M, Abe S, Kasai M, Sugiura T, Kobayashi H (2011) Contribution of understory vegetation to minimizing nitrate leaching in a Japanese cedar plantation. Journal of Forest Research 16(6):446-455. doi:10.1007/s10310-010-0244-3

- Banabas M, Scotter DR, Turner MA (2008a) Losses of nitrogen fertiliser under oil palm in Papua New Guinea: 2. Nitrogen transformations and leaching, and a residence time model. Soil Research 46(4):340-347. doi:10.1071/SR07174

- Banabas M, Turner MA, Scotter DR, Nelson PN (2008b) Losses of nitrogen fertiliser under oil palm in Papua New Guinea: 1. Water balance, and nitrogen in soil solution and runoff. Australian Journal of Soil Research 46(4):332-339. doi:10.1071/SR07171 
- Bates D, Maechler M, Bolker B, Walker S (2015) Fitting linear mixed-effect models using lme4. Journal of Statistical Software 67(1):1-48

- Boafo DK, Kraisornpornson B, Panphon S, Owusu BE, Amaniampong PN (2020)

Effect of organic soil amendments on soil quality in oil palm production. Applied Soil Ecology 147:103358. doi:10.1016/j.apsoil.2019.09.008

- Cannavo P, Harmand J-M, Zeller B, Vaast P, Ramírez JE, Dambrine E (2013) Low nitrogen use efficiency and high nitrate leaching in a highly fertilized Coffea arabica-Inga densiflora agroforestry system: a 15N labeled fertilizer study. Nutrient Cycling in Agroecosystems 95:377-394. doi:10.1007/s10705-013-9571-z

- Carlson KM, Curran LM, Asner GP, Pittman AM, Trigg SN, Marion Adeney J (2013) Carbon emissions from forest conversion by Kalimantan oil palm plantations. Nature Climate Change 3(3):283-287. doi:10.1038/nclimate1702

- Carpenter SR, Caraco NF, Correll DL, Howarth RW, Sharpley AN, Smith VH (1998) Nonpoint pollution of surface waters with phosphorus and nitrogen. Ecological Applications 8(3):559-568. doi:10.1890/1051-0761(1998)008[0559:NPOSWW]2.0.CO;2

- Carter C, Finley W, Fry J, Jackson D, Willis L (2007) Palm oil markets and future supply. European Journal of Lipid Science and Technology 109(4):307-314. doi:10.1002/ejlt.200600256

- Chellaiah D, Yule CM (2018) Effect of riparian management on stream morphometry and water quality in oil palm plantations in Borneo. Limnologica 69:72-80. doi:10.1016/j.limno.2017.11.007

- Chou C, Chiang JCH, Lan C-W, Chung C-H, Liao Y-C, Lee C-J (2013) Increase in the range between wet and dry season precipitation. Nature Geoscience 6(4):263-267. doi:10.1038/ngeo1744

- Clough Y, Krishna VV, Corre MD, Darras K, Denmead LH, Meijide A, Moser S, Musshoff O, Steinebach S, Veldkamp E, Allen K, Barnes AD, Breidenbach N, Brose U, Buchori D, Daniel R, Finkeldey R, Harahap I, Hertel D, Holtkamp AM, Hörandl E, Irawan B, Jaya INS, Jochum M, Klarner B, Knohl A, Kotowska MM, Krashevska V, Kreft H, Kurniawan S, Leuschner C, Maraun M, Melati DN, Opfermann N, Pérez-Cruzado C, Prabowo WE, Rembold K, Rizali A, Rubiana R, Schneider D, Tjitrosoedirdjo SS, Tjoa A, Tscharntke T, Scheu S (2016) Land-use choices follow profitability at the expense of ecological functions in Indonesian smallholder landscapes. Nature Communications 7:13137. doi:10.1038/ncomms13137

- Comte I, Colin F, Grünberger O, Follain S, Whalen JK, Caliman J-P (2013) Landscape-scale assessment of soil response to long-term organic and mineral 
fertilizer application in an industrial oil palm plantation, Indonesia. Agriculture, Ecosystems \& Environment 169:58-68. doi:10.1016/j.agee.2013.02.010

- Corley RHV (2009) How much palm oil do we need? Environmental Science \& Policy 12(2):134-139. doi:10.1016/j.envsci.2008.10.011

- Corley RHV, Tinker PB (2016) The oil palm, 5th ed. John Wiley \& Sons, Ltd, Hoboken, NJ

- Corre MD, Veldkamp E, Arnold J, Wright SJ (2010) Impact of elevated N input on soil $\mathrm{N}$ cycling and losses in old-growth lowland and montane forests in Panama. Ecology 91(6):1715-1729. doi:10.1890/09-0274.1

- Cusack DF, Silver W, McDowell WH (2009) Biological nitrogen fixation in two tropical forests: ecosystem-level patterns and effects of nitrogen fertilization.

Ecosystems 12(8):1299-1315. doi:10.1007/s10021-009-9290-0

- Darras KFA, Corre MD, Formaglio G, Tjoa A, Potapov A, Brambach F, Sibhatu KT, Grass I, Rubiano AA, Buchori D, Drescher J, Fardiansah R, Hölscher D, Irawan B, Kneib T, Krashevska V, Krause A, Kreft H, Li K, Maraun M, Polle A, Ryadin AR, Rembold K, Stiegler C, Scheu S, Tarigan S, Valdés-Uribe A, Yadi S, Tscharntke T, Veldkamp E (2019) Reducing fertilizer and avoiding herbicides in oil palm plantations-ecological and economic valuations. Frontiers in Forests and Global Change 2. doi:10.3389/ffgc.2019.00065

- Dechert G, Veldkamp E, Brumme R (2005) Are partial nutrient balances suitable to evaluate nutrient sustainability of land use systems? Results from a case study in central Sulawesi, Indonesia. Nutrient Cycling in Agroecosystems 72(3):201-212. doi:10.1007/s10705-005-1546-2

- Drescher J, Rembold K, Allen K, Beckschäfer P, Buchori D, Clough Y, Faust H, Fauzi AM, Gunawan D, Hertel D, Irawan B, Jaya INS, Klarner B, Kleinn C, Knohl A, Kotowska MM, Krashevska V, Krishna V, Leuschner C, Lorenz W, Meijide A, Melati D, Nomura M, Pérez-Cruzado C, Qaim M, Siregar IZ, Steinebach S, Tjoa A, Tscharntke T, Wick B, Wiegand K, Kreft H, Scheu S (2016) Ecological and socio-economic functions across tropical land use systems after rainforest conversion. Philosophical Transactions of the Royal Society of London. Series B, Biological sciences 371(1694). doi:10.1098/rstb.2015.0275

- Dubos B, Snoeck D, Flori A (2017) Excessive use of fertilizer can increase leaching processes and modify soil reserves in two Ecuadorian oil palm plantations.

Experimental Agriculture 53(2):255-268. doi:10.1017/S0014479716000363

- Edy N, Yelianti U, Irawan B, Polle A, Pena R (2020) Differences in root nitrogen uptake between tropical lowland rainforests and oil palm plantations. Frontiers in 
Plant Science 11:92. doi:10.3389/fpls.2020.00092

- Elsenbeer H (2001) Hydrologic flowpaths in tropical rainforest soilscapes - a review. Hydrological Processes 15(10):1751-1759. doi:10.1002/hyp.237

- Fan Y, Roupsard O, Bernoux M, Le Maire G, Panferov O, Kotowska MM, Knohl A (2015) A sub-canopy structure for simulating oil palm in the Community Land Model (CLM-Palm): phenology, allocation and yield. Geoscientific Model Development 8(11):3785-3800. doi:10.5194/gmd-8-3785-2015

- FAO (2018) Food and Agricolture Organization, FAOSTAT. http:/ / faostat.fao.org/site/339/default.aspx. Accessed 30 Mar 2020

- Feng X, Porporato A, Rodriguez-Iturbe I (2013) Changes in rainfall seasonality in the tropics. Nature Climate Change 3(9):811-815. doi:10.1038/nclimate1907

- Figueiredo RO, Markewitz D, Davidson EA, Schuler AE, Watrin OdS, Silva PdS (2010) Land-use effects on the chemical attributes of low-order streams in the eastern Amazon. Journal of Geophysical Research 115(G04004). doi:10.1029/2009JG001200

- Fukuzawa K, Shibata H, Takagi K, Nomura M, Kurima N, Fukazawa T, Satoh F, Sasa K (2006) Effects of clear-cutting on nitrogen leaching and fine root dynamics in a cool-temperate forested watershed in northern Japan. Forest Ecology and Management 225(1-3):257-261. doi:10.1016/j.foreco.2006.01.001

- Geist HJ, Lambin EF (2002) Proximate causes and underlying driving forces of tropical deforestation. BioScience 52(2):143-150.

doi:10.1641/0006-3568(2002)052[0143:PCAUDF]2.0.CO;2

- Gibbs HK, Ruesch AS, Achard F, Clayton MK, Holmgren P, Ramankutty N, Foley JA (2010) Tropical forests were the primary sources of new agricultural land in the 1980s and 1990s. Proceedings of the National Academy of Sciences of the United States of America 107(38):16732-16737. doi:10.1073/pnas.0910275107

- Goh K-J, Härdter R, Fairhurst T (2003) Fertilizing for maximum return. Oil Palm Management for Large and Sustainable Yields:279-306

- Grass I, Kubitza C, Krishna VV, Corre MD, Mußhoff O, Pütz P, Drescher J, Rembold K, Ariyanti ES, Barnes AD, Brinkmann N, Brose U, Brümmer B, Buchori D, Daniel R, Darras KFA, Faust H, Fehrmann L, Hein J, Hennings N, Hidayat P, Hölscher D, Jochum M, Knohl A, Kotowska MM, Krashevska V, Kreft H, Leuschner C, Lobite NJS, Panjaitan R, Polle A, Potapov AM, Purnama E, Qaim M, Röll A, Scheu S, Schneider D, Tjoa A, Tscharntke T, Veldkamp E, Wollni M (2020) Trade-offs between multifunctionality and profit in tropical smallholder landscapes. Nature Communications 11(1):1186. doi:10.1038/s41467-020-15013-5 
- Harmand J-M, Ávila H, Oliver R, Saint-André L, Dambrine E (2010) The impact of kaolinite and oxi-hydroxides on nitrate adsorption in deep layers of a Costarican Acrisol under coffee cultivation. Geoderma 158(3-4):216-224.

doi:10.1016/j.geoderma.2010.04.032

- Haron K, Brookes PC, Anderson JM, Zakaria ZZ (1998) Microbial biomass and soil organic matter dynamics in oil palm (Elaeis Guineensis Jacq.) plantations, West Malaysia. Soil Biology and Biochemistry 30(5):547-552.

doi:10.1016/S0038-0717(97)00217-4

- Hodge A (2004) The plastic plant: root responses to heterogeneous supplies of nutrients. New Phytologist 162(1):9-24. doi:10.1111/j.1469-8137.2004.01015.x

- Hothorn T, Bretz F, Westfall P (2008) Simultaneous inference in general parametric models. Biometrical Journal 50(3):346-363

- Huddell AM, Galford GL, Tully KL, Crowley C, Palm CA, Neill C, Hickman JE, Menge DNL (2020) Meta-analysis on the potential for increasing nitrogen losses from intensifying tropical agriculture. Global Change Biology 26(3):1-13.

doi:10.1111/gcb.14951

- Jankowski K, Neill C, Davidson EA, Macedo MN, Costa CJ, Galford GL, Santos LM, Lefebvre P, Nunes D, Cerri CEP, McHorney R, O'Connell C, Coe MT (2018) Deep soils modify environmental consequences of increased nitrogen fertilizer use in intensifying Amazon agriculture. Scientific Reports(8):13478.

doi:10.1038/s41598-018-31175-1

- Kaspari M, Yanoviak SP, Dudley R, Yuan M, Clay NA (2009) Sodium shortage as a constraint on the carbon cycle in an inland tropical rainforest. Proceedings of the National Academy of Sciences of the United States of America 106(46):19405-19409. doi:10.1073/pnas.0906448106

- Kotowska MM, Leuschner C, Triadiati T, Hertel D (2016) Conversion of tropical lowland forest reduces nutrient return through litterfall, and alters nutrient use efficiency and seasonality of net primary production. Oecologia 180:601-618. doi:10.1007/s00442-015-3481-5

- Kotowska MM, Leuschner C, Triadiati T, Meriem S, Hertel D (2015) Quantifying above- and belowground biomass carbon loss with forest conversion in tropical lowlands of Sumatra (Indonesia). Global Change Biology 21(10):3620-3634.

doi:10.1111/gcb.12979

- Kurniawan S, Corre MD, Matson AL, Schulte-Bisping H, Utami SR, van Straaten O, Veldkamp E (2018) Conversion of tropical forests to smallholder rubber and oil palm 
plantations impacts nutrient leaching losses and nutrient retention efficiency in highly weathered soils. Biogeosciences 15:5131-5154. doi:10.5194/bg-15-5131-2018

- Kuznetsova A, Brockhoff PB, Christensen RHB (2017) LmerTest package: tests in linear mixed effects models. Journal of Statistical Software 82(13):1-26. doi:10.18637/jss.v082.i13

- Lamade E, Djegui N, Leterme, P (1996) Estimation of carbon allocation to the roots from soil respiration measurements of oil palm. Plant and Soil 181 (2):329-339. doi:10.1007/BF00012067.

- Li Y, Ghodrati M (1994) Preferential transport of nitrate through soil columns containing root channels. Soil Science Society of America Journal 58(3):653-659. doi:10.2136/sssaj1994.03615995005800030003x

- Lohse KA, Matson P (2005) Consequences of nitrogen additions for soil losses from wet tropical forests. Ecological Applications 15(5):1629-1648. doi:10.1890/03-5421 - Luke SH, Barclay H, Bidin K, Chey VK, Ewers RM, Foster WA, Nainar A, Pfeifer M, Reynolds G, Turner EC, Walsh RPD, Aldridge DC (2017) The effects of catchment and riparian forest quality on stream environmental conditions across a tropical rainforest and oil palm landscape in Malaysian Borneo. Ecohydrology: ecosystems, land and water process interactions, ecohydrogeomorphology 10(4):1-17. doi:10.1002/eco.1827 - Luke SH, Purnomo D, Advento AD, Aryawan AAK, Naim M, Pikstein RN, Ps S, Rambe TDS, Soeprapto, Caliman J-P, Snaddon JL, Foster WA, Turner EC (2019) Effects of understory vegetation management on plant communities in oil palm plantations in Sumatra, Indonesia. Frontiers in Forests and Global Change 2:1-13. doi:10.3389/ffgc.2019.00033

- Meijide A, La Rua C de, Guillaume T, Röll A, Hassler E, Stiegler C, Tjoa A, June T, Corre MD, Veldkamp E, Knohl A (2020) Measured greenhouse gas budgets challenge emission savings from palm-oil biodiesel. Nature Communications 11(1):1089. doi:10.1038/s41467-020-14852-6

- Meijide A, Röll A, Fan Y, Herbst M, Niu F, Tiedemann F, June T, Rauf A, Hölscher D, Knohl A (2017) Controls of water and energy fluxes in oil palm plantations: environmental variables and oil palm age. Agricultural and Forest Meteorology 239:71-85. doi:10.1016/j.agrformet.2017.02.034

- Ministry of Agriculture of Indonesia (2016) Oil palm replanting guideline. Regulation No: 18/Permentan/KB.330/5/2016

- Mohanty S, Swain CK, Tripathi R, Sethi SK, Bhattacharyya P, Kumar A, Raja R, Shahid M, Panda BB, Lal B, Gautam P, Munda S, Nayak AK (2018) Nitrate leaching, nitrous oxide emission and $\mathrm{N}$ use efficiency of aerobic rice under different $\mathrm{N}$ 
application strategy. Archives of Agronomy and Soil Science 64(4):465-479. doi:10.1080/03650340.2017.1359414

- Moradi A, Teh CBS, Goh KJ, Husni AMH, Ishak CF (2015) Effect of four soil and water conservation practices on soil physical processes in a non-terraced oil palm plantation. Soil and Tillage Research 145:62-71. doi:10.1016/j.still.2014.08.005 - Murdiyarso D, Hergoualc'h K, Verchot LV (2010) Opportunities for reducing greenhouse gas emissions in tropical peatlands. PNAS 107(46):19655-19660. doi:10.1073/pnas.0911966107

- Neill C, Coe MT, Riskin SH, Krusche AV, Elsenbeer H, Macedo MN, McHorney R, Lefebvre P, Davidson EA, Scheffler R, Figueira AMeS, Porder S, Deegan LA (2013) Watershed responses to Amazon soya bean cropland expansion and intensification. Philosophical Transactions of the Royal Society of London. Series B, Biological sciences 368:20120425. doi:10.1098/rstb.2012.0425

- Nelson PN, Banabas M, Scotter DR, Webb MJ (2006) Using soil water depletion to measure spatial distribution of root activity in oil palm (Elaeis Guineensis Jacq.) plantations. Plant and Soil 286:109-121. doi:10.1007/s11104-006-9030-6

- Nyamangara J, Bergström LF, Piha MI, Giller KE (2003) Fertilizer use efficiency and nitrate leaching in a tropical sandy soil. Journal of environmental quality 32(2):599-606. doi:10.2134/jeq2003.5990

- Olsson MO, Falkengren-Grerup U (2003) Partitioning of nitrate uptake between trees and understory in oak forests. Forest Ecology and Management 179(1-3):311-320. doi:10.1016/S0378-1127(02)00544-3

- Omoti U, Ataga DO, Isenmila AE (1983) Leaching losses of nutrients in oil palm plantations determined by tension lysimeters. Plant and Soil 73:365-376.

doi:10.1007/BF02184313

- Pahan I (2010) Complete guide to oil palm, 8th edn. Penebar Swadaya, Jakarta, Indonesia

- Pardon L, Bessou C, Nelson PN, Dubos B, Ollivier J, Marichal R, Caliman J-P, Gabrielle B (2016) Key unknowns in nitrogen budget for oil palm plantations. A review. Agronomy for Sustainable Development 36(1):20.

doi:10.1007/s13593-016-0353-2

- Pirker J, Mosnier A, Kraxner F, Havlík P, Obersteiner M (2016) What are the limits to oil palm expansion? Global Environmental Change 40:73-81. doi:10.1016/j.gloenvcha.2016.06.007

- Priesack E (2005) Expert-N model library documentation. Institute of Soil Ecology 
- R Core Team (2019) R: A language and environment for statistical computing. Foundation for Statistical Computing, Vienna, Austria

- Rahman N, Neergaard A de, Magid J, van de Ven GWJ, Giller KE, Bruun TB (2018) Changes in soil organic carbon stocks after conversion from forest to oil palm plantations in Malaysian Borneo. Environmental Research Letters 13(10):105001. doi:10.1088/1748-9326/aade0f

- Röll A, Niu F, Meijide A, Ahongshangbam J, Ehbrecht M, Guillaume T, Gunawan D, Hardanto A, Hendrayanto, Hertel D, Kotowska MM, Kreft H, Kuzyakov Y, Leuschner C, Nomura M, Polle A, Rembold K, Sahner J, Seidel D, Zemp DC, Knohl A, Hölscher D (2019) Transpiration on the rebound in lowland Sumatra. Agricultural and Forest Meteorology 274:160-171. doi:10.1016/j.agrformet.2019.04.017

- Roy ED, Richards PD, Martinelli LA, Della Coletta L, Lins SRM, Vazquez FF, Willig E, Spera SA, VanWey LK, Porder S (2016) The phosphorus cost of agricultural intensification in the tropics. Nature plants 2(5):16043. doi:10.1038/nplants.2016.43 - Rüegg J, Quezada JC, Santonja M, Ghazoul J, Kuzyakov Y, Buttler A, Guillaume T (2019) Drivers of soil carbon stabilization in oil palm plantations. Land Degrad Dev 30(16):1-12. doi:10.1002/ldr.3380

- Schlesinger WH, Bernhardt ES (2013) Biogeochemistry. An analysis of global change, 3rd ed. Academic Press, Waltham, Mass

- Schroth G, Rodrigues MRL, D'Angelo SA (2000) Spatial patterns of nitrogen mineralization, fertilizer distribution and roots explain nitrate leaching from mature Amazonian oil palm plantation. Soil Use and Management 16:222-229. doi:10.1111/j.1475-2743.2000.tb00197.x

- Silver WL, Thompson AW, Reich A, Ewel JJ, Firestone MK (2005) Nitrogen cycling in tropical plantation forests: potential controls on nitrogen retention. Ecological Applications 15(5):1604-1614. doi:10.1890/04-1322

- Steiner C, Glaser B, Geraldes Teixeira W, Lehmann J, Blum WEH, Zech W (2008) Nitrogen retention and plant uptake on a highly weathered central Amazonian Ferralsol amended with compost and charcoal. J. Plant Nutr. Soil Sci. 171(6):893-899. doi:10.1002/jpln.200625199

- Tarigan S, Stiegler C, Wiegand K, Knohl A, Murtilaksono K (2020) Relative contribution of evapotranspiration and soil compaction to the fluctuation of catchment discharge: case study from a plantation landscape. Hydrological Sciences Journal 58(6):1-10. doi:10.1080/02626667.2020.1739287

- Tarigan S, Wiegand K, Sunarti, Slamet B (2018) Minimum forest cover required for sustainable water flow regulation of a watershed: a case study in Jambi Province, 
Indonesia. Hydrology and Earth System Sciences 22(1):581-594.

doi:10.5194/hess-22-581-2018

- Tarigan SD, Sunarti, Wiegand K, Dislich C, Slamet B, Heinonen J, Meyer K (2016)

Mitigation options for improving the ecosystem function of water flow regulation in a watershed with rapid expansion of oil palm plantations. Sustainability of Water Quality and Ecology 8:4-13. doi:10.1016/j.swaqe.2016.05.001

- Teklu BM, Hailu A, Wiegant DA, Scholten BS, van den Brink PJ (2018) Impacts of nutrients and pesticides from small- and large-scale agriculture on the water quality of Lake Ziway, Ethiopia. Environmental Science and Pollution Research 25(14):13207-13216. doi:10.1007/s11356-016-6714-1

- Tokuchi N, Samejima H, Hon J, Fukushima K (2019) Influence of herbicide use in oil palm plantations on stream water chemistry in Sarawak. Anthropogenic Tropical Forests:209-216. doi:10.1007/978-981-13-7513-2-11

- Tully KL, Lawrence D, Scanlon TM (2012) More trees less loss: nitrogen leaching losses decrease with increasing biomass in coffee agroforests. Agriculture, Ecosystems \& Environment 161:137-144. doi:10.1016/j.agee.2012.08.002

- Tung PGA, Yusoff MK, Majid NM, Joo GK, Huang GH (2009) Effect of N and K fertilizers on nutrient leaching and groundwater quality under mature oil palm in Sabah during the monsoon period. American Journal of Applied Sciences 6(10):1788-1799

- van Breemen N, Mulder J, Driscoll CT (1983) Acidification and alkalization of soils. Plant and Soil 75:283-308

- van Bruggen AHC, He MM, Shin K, Mai V, Jeong KC, Finckh MR, Morris JG (2018) Environmental and health effects of the herbicide glyphosate. Science of the Total Environment 616-617:255-268. doi:10.1016/j.scitotenv.2017.10.309

- van Straaten O, Corre MD, Wolf K, Tchienkoua M, Cuellar E, Matthews RB, Veldkamp E (2015) Conversion of lowland tropical forests to tree cash crop plantations loses up to one-half of stored soil organic carbon. Proceedings of the National Academy of Sciences 112(32):9956-9960. doi:10.1073/pnas.1504628112

- Vijay V, Pimm SL, Jenkins CN, Smith SJ (2016) The Impacts of Oil Palm on Recent Deforestation and Biodiversity Loss. PloS One 11(7):e0159668.

doi:10.1371/journal.pone.0159668

- Wakelin SA, Nelson PN, Armour JD, Rasiah V, Colloff MJ (2011) Bacterial community structure and denitrifier (nir-gene) abundance in soil water and groundwater beneath agricultural land in tropical North Queensland, Australia. Soil Research 49(1):65-76. doi:10.1071/SR10055 
- WHO (2011) Guidelines for drinking-water quality, 4th ed. World Health Organization, Geneva

- Wong MTF, Hughes R, Rowell DL (1990) Retarded leaching of nitrate in acid soils from the tropics: measurement of the effective anion exchange capacity. Journal of Soil Science(41):655-663

- Woodham CR, Aryawan AAK, Luke SH, Manning P, Caliman J-P, Naim M, Turner EC, Slade EM (2019) Effects of replanting and retention of mature oil palm riparian buffers on Ecosystem functioning in oil palm plantations. Frontiers in Forests and Global Change 2:29. doi:10.3389/ffgc.2019.00029 
Chapter 5

Synthesis 


\subsection{Effect of reduced management intensity}

Our experiment showed that the reduction of management intensity had generally no effect on soil nutrient contents, soil-N cycling rates or asymbiotic $\mathrm{N}_{2}$ fixation, but it was effective in reducing nutrient leaching losses, an important environmental footprint of large-scale oil palm plantations. In particular, the leaching losses of $\mathrm{N}$ and $\mathrm{Al}$, two potential water pollutants, were diminished by $44 \%$ and $53 \%$, respectively.

We found that the reduced fertilization treatment had comparable nutrient contents to the conventional fertilization despite lower nutrient inputs. Soil mineral N contents, although on average higher in the conventional than in the reduced fertilization treatments, did not show significant effects of reduced $\mathrm{N}$ application (Fig. 1), despite mineral $\mathrm{N}$ reacts fast to changes due to its fast turnover (low mean residence time, Chapter 2). It is likely that the excess of $\mathrm{N}$ applied in conventional compared to reduced fertilization treatments is mostly leached, as shown by high leaching losses occurring after fertilization and by the reduction of $\mathrm{N}$ leaching with reduced fertilization rates (Chapter 4). This is further supported by lack of treatment effects on microbial biomass $\mathrm{N}$ (Chapter 2), which is also a fast reacting pool, suggesting that the microbial biomass is not using the excess $\mathrm{N}$. All these results indicate that the plantation was over-fertilized with N. As for K, the reduced fertilization treatments added only $15 \%$ less $\mathrm{K}$ than the conventional fertilization treatments, due to the high $\mathrm{K}$ content in the fruit bunches (Chapter 2). It is likely that the $\mathrm{K}$ fertilization treatments did not have effects on soil nutrient contents because of this low reduction, but some effects may emerge in the long-run of this experiment. Similarly, effects of $P$ fertilization may be difficult to detect because fertilization with $\mathrm{P}$ in both conventional and reduced treatments was relatively low compared to $\mathrm{N}$ and $\mathrm{K}$. 
Figure 1: Annual average soil mineral $N$ (mean $\pm S E, n=4$ plots) in the top-5-cm depth in each experimental treatment and management zone in a large-scale oil palm plantation in Jambi, Indoensia.

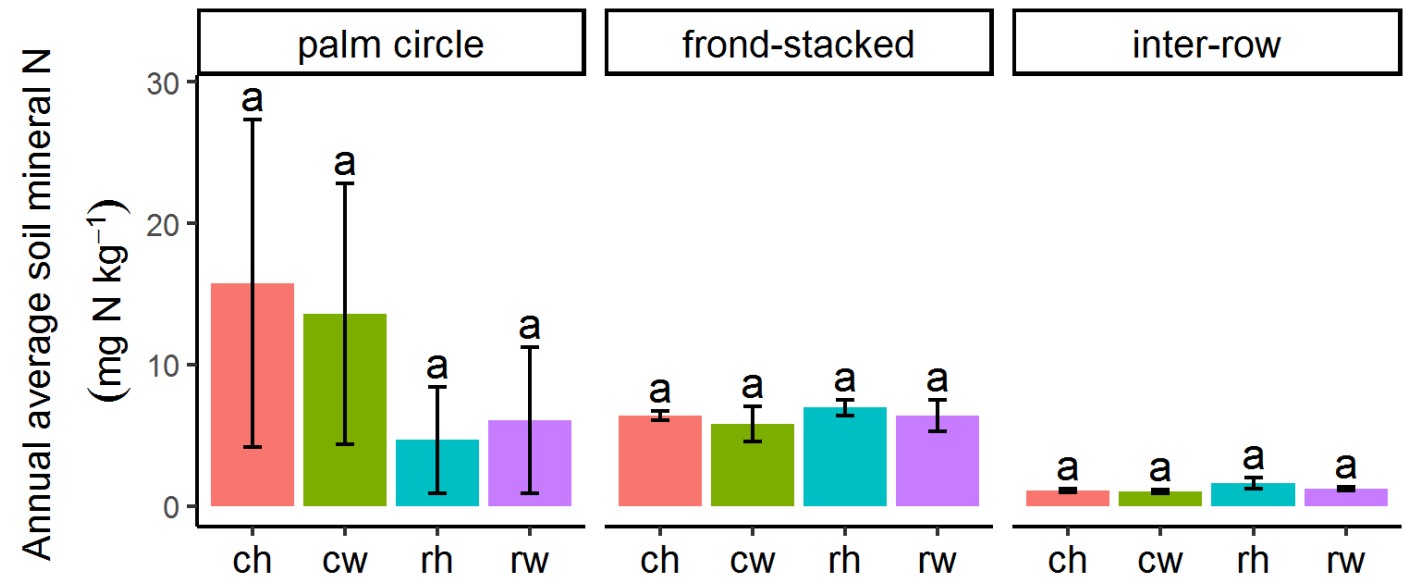

The same lowercase letters indicate no differences among treatments in each management zone (linear-mixed effect models on monthly values followed by ANOVA at $\mathrm{p} \leq$ 0.05)

Treatments: $\mathrm{ch}=$ conventional fertilization-herbicide; $\mathrm{cw}=$ conventional fertilization-mechanical weeding; $r h=$ reduced fertilization-herbicide; $r w=$ reduced fertilization-mechanical weeding.

The rates of lime application were kept constant across treatments in our management experiment. The high $\mathrm{pH}$ found in the palm circle showed that liming was effective in compensating the acidifying effect of nitrification from urea application (Dubos et al. 2017), also considering the high rates of nitrification in our plantation (Chapter 2). Nevertheless, since the base saturation in the palm circle was very high (100\% in the top $5 \mathrm{~cm}$ of soil; Chapter 2), lime application could be reduced, especially in the reduced fertilization treatment with lower urea application, in order to reduce the leaching of $\mathrm{Ca}$ (Chapter 4). Alternatively, the lime could in part be broadcasted also to the inter-row, where there was low $\mathrm{pH}$ and high $\mathrm{Al}$ saturation (Chapter 4).

Manual weeding increased the vegetation cover compared to herbicide weeding treatments (Darras et al. 2019), which resulted in more efficient retention of nutrients in the top-soil and lower leaching losses (Chapter 4). Also, the mechanical weeding 
treatments showed a trend (although not significant) of higher $\mathrm{pH}$ and base saturation in the inter-row compared to herbicide weeding treatment (Fig. 2). This is probably due to higher base cations retention by the understory vegetation (Baba et al. 2011), and suggests that a positive effect on soil fertility might emerge in the long-run of this experiment.

Figure 2: Soil $\mathrm{pH}$ and base saturation in the top-5-cm depth in each experimental treatment and management zone in a large-scale oil palm plantation in Jambi, Indoensia.

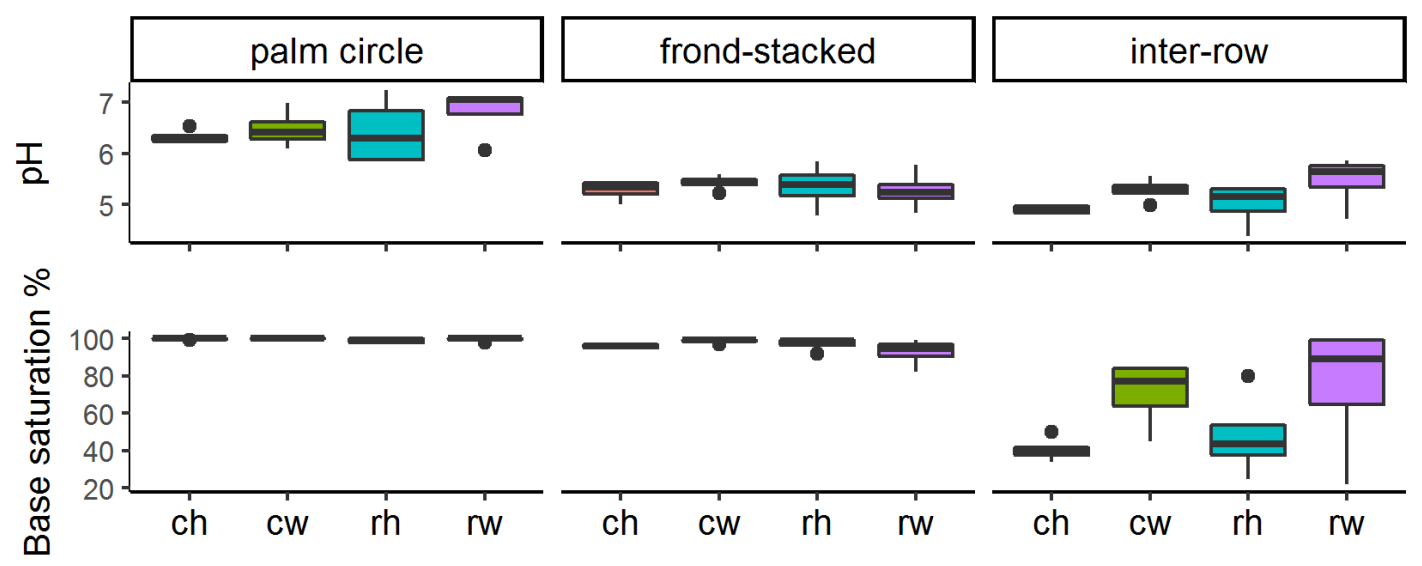

Treatments: $\mathrm{ch}=$ conventional fertilization-herbicide; $\mathrm{cw}=$ conventional fertilization-mechanical weeding; $r$ h = reduced fertilization-herbicide; $r w=$ reduced fertilization-mechanical weeding.

Together with the positive effects on soil fertility, mechanical weeding also increases water infiltration in the soil, thus reducing runoff, compared to the conventional herbicide application, and have positive effects on soil biota: it recorded higher decomposer animal metabolism, belowground animals group richness, and aboveground insect family richness than the herbicide treatment (Darras et al. 2019). Regarding the economic impacts, management costs were comparable between herbicide and mechanical weeding, because periodical manual removal of woody vegetation is necessary also with herbicide application (Darras et al. 2019, Pahan 2010).

The reduction of management intensity may lead to some nutrient deficiencies that may affect fruit development of the oil palm, thus affecting the yield. The effect of 
stresses on fruit development should start to emerge 20-30 months after the occurrence of the stress, because of the development period from floral initiation to fruit maturity in oil palms (Tiemann et al. 2018). In an experiment on the application of empty fruit bunches in an oil palm plantation the yield reacted with two year lag-time (Tao et al. 2017), whereas in an experiment on manuring the first effects on fruit production emerged after nine months and peaked after 4-6 years (Sidhu et al. 2009). In our experiment, the yield, measured up to three years after the establishment of the experiment, was comparable among the experimental treatments (Fig. 3), probably because there was no reduction on soil nutrient contents. This indicated that the reduction of management intensity did not reduce the plantation productivity in the first years of this management experiment but some effects may emerge in the long-run of this experiment.

Figure 3: Annual yield in 2017, 2018 and 2019 in each experimental treatment in a large-scale oil palm plantation in Jambi, Indoensia.

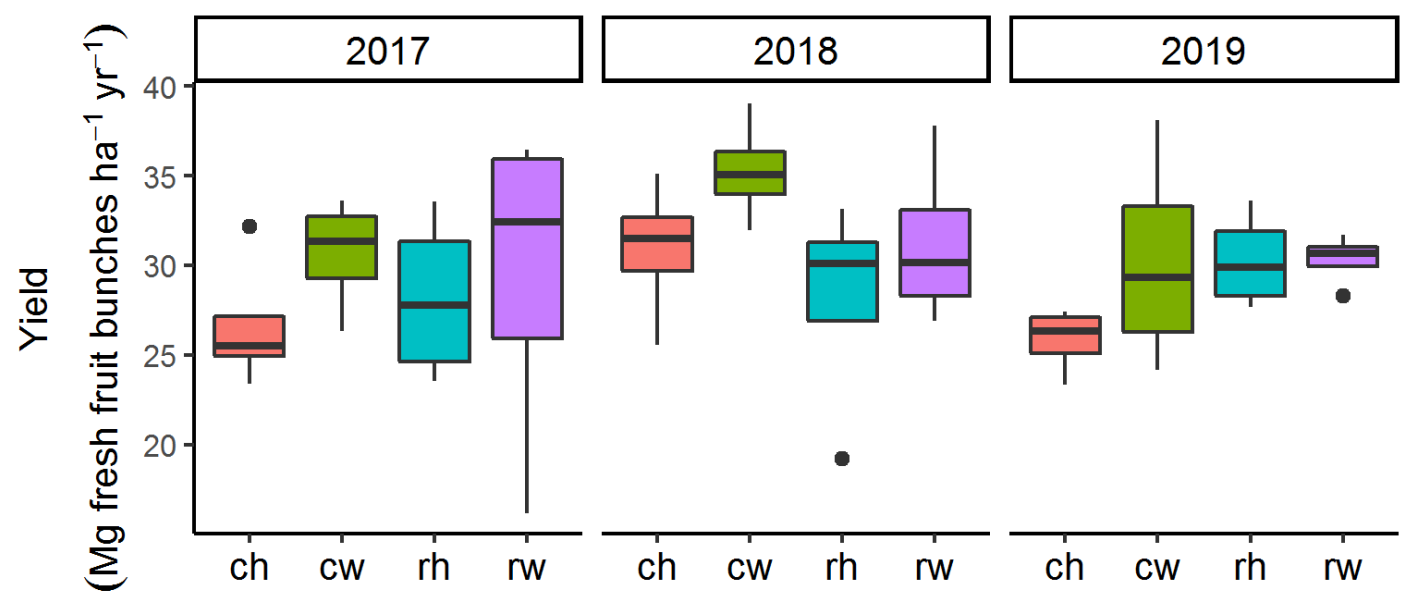

Treatments: $\mathrm{ch}=$ conventional fertilization-herbicide; $\mathrm{cw}=$ conventional fertilization-mechanical weeding; $r$ = reduced fertilization-herbicide; rw = reduced fertilization-mechanical weeding.

Long-term monitoring is critical to show effects on the long run but it is often complicated due to limited resources. Since the yield is routinely monitored in large-scale plantations, it could be possible to establish permanent experimental plots 
inside large-scale oil palm plantations for assessing different management practices. This practice should be advocated by the government, and compensations for eventual yield reduction should be set in place.

In conclusion, this management experiment defined some management practices that could help to reduce the environmental footprint of large-scale oil palm plantation. The results could be used as research-based evidence for the development of precision farming in oil palm plantations, in line with the objectives of the Indonesian government (Ministry of Agriculture of Indonesia 2016), as well as for recommendations on sustainable management by the Roundtable of Sustainable Oil Palm (RSPO 2018). Other practices that could restore some ecosystem services in oil palm plantations, such as enhanced understory vegetation (Luke et al. 2020) or enriched tree diversity (Teuscher et al. 2016), should be also investigated for their impacts on soil fertility indices as well as for productivity.

\subsection{Spatial differences in the oil palm plantation}

Another important aspect highlighted in this research is the spatial variability of soil functions inside the plantation, according to the management zones. This point out to the importance of taking into account the management zones when measuring soil parameters in oil palm plantations. Soil fluxes and stocks of the main nutrients supplied via fertilizer and lime ( $\mathrm{N}, \mathrm{K}$ and $\mathrm{Ca})$ in each management zone are summarized in Figure 4.

Atmospheric input via precipitation was not included because it was considered similar among management zones, as the difference in interception between palm circle and the other zones was just of $142 \mathrm{~mm} \mathrm{yr}^{-1}$ (Chapter 4). The rates of asymbiotic $\mathrm{N}_{2}$ fixation were generally in the same order of magnitude as soil $\mathrm{N}_{2} \mathrm{O}$ emissions, and both were minor $\mathrm{N}$ fluxes compared to the other inputs and outputs (Fig. 4).

The frond-stacked area had high $\mathrm{N}$ and Ca inputs from the decomposition of 
fronds, which were especially rich in these elements (Chapter 3), as they were supplied to the palm via fertilization and liming (Fig. 4). The input of $K$ from the decomposition of fronds was lower than $\mathrm{N}$ and $\mathrm{Ca}$, despite the high rates of $\mathrm{K}$ fertilization, because most of the $\mathrm{K}$ taken by the palms is stored in the fruit bunches, which have high $\mathrm{K}$ contents (3.8 and $62.6 \mathrm{mg} \mathrm{g}^{-1}$ in the fruit and stalks, respectively, Chapter 2). Because of these nutrient inputs from decomposition, the frond-stacked area had generally high nutrient contents: soil Ca was comparable to the limed palm circle and soil $\mathrm{N}$ was even higher than the fertilized palm circle (Fig. 4). These high $\mathrm{N}$ contents are the result of high gross $\mathrm{N}$ mineralization and of efficient $\mathrm{N}$ retention by a large microbial biomass, which is sustained by high soil organic matter (Chapter 2). 
Figure 4: Fluxes and soil pools of $\mathrm{N}, \mathrm{K}$, and $\mathrm{Ca}$ (mean (standard error), $\mathrm{n}=4$ plots) in each management zone, in the conventional fertilization-herbicide treatment in the large-scale oil palm plantation in Jambi, Indoensia. Fluxes are in $\mathrm{kg} \mathrm{ha}^{-1} \mathrm{yr}^{-1}$ and pools in $\mathrm{kg}^{-1} \mathrm{ha}^{-1}$; microbial biomass $\mathrm{N}$ measured in the top-5-cm depth and soil nutrient contents for the top-50-cm depth.

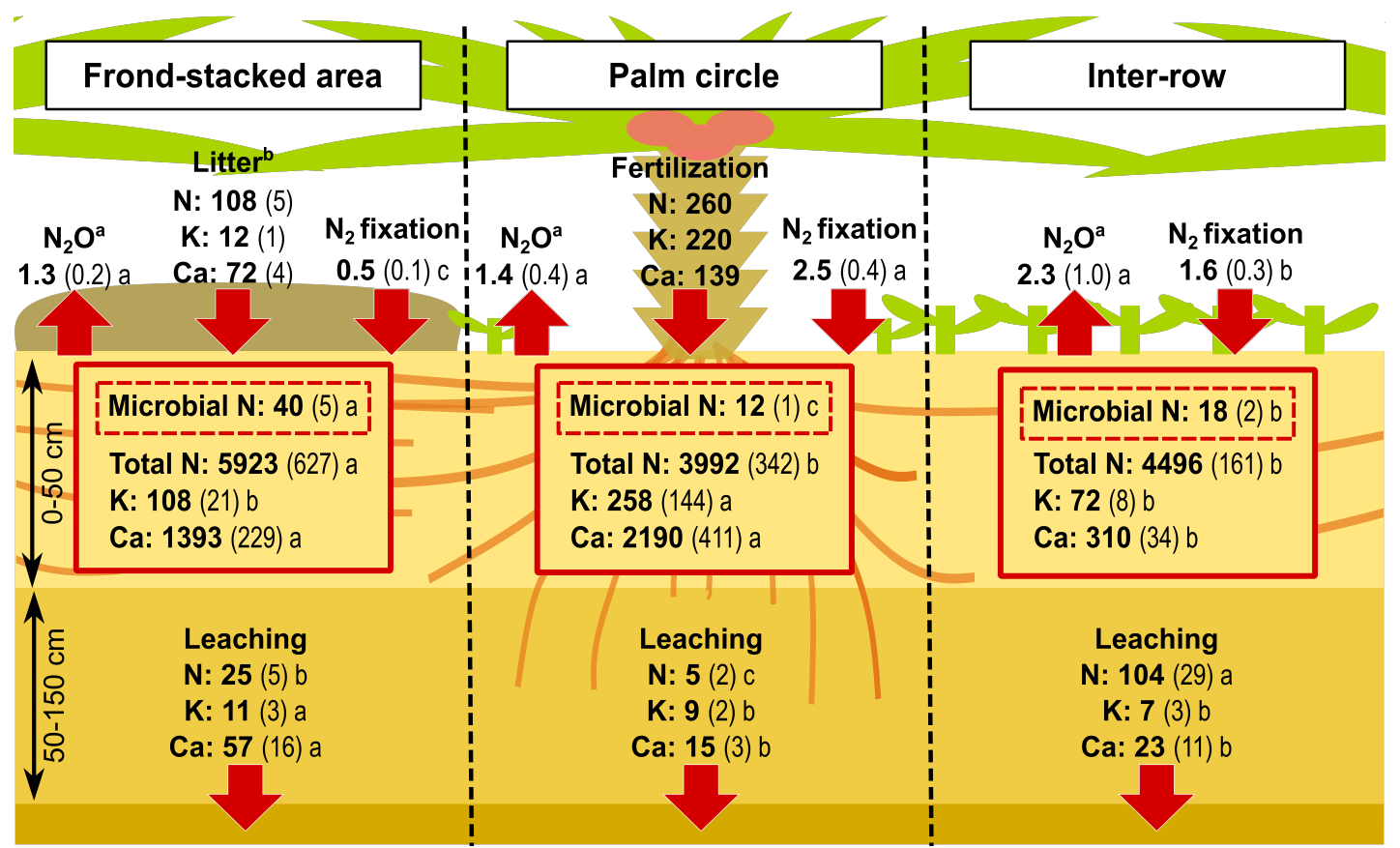

Means followed by different letters indicate significant differences among management zones (linear mixed effects models with Tukey HSD at $\mathrm{p} \leq 0.05$ on monthly data for fluxes, and one-way ANOVA with Tukey HSD or Kruskal-Wallis H test with multiple comparisons extension at $\mathrm{p} \leq 0.05$ for nutrient pools).

${ }^{\text {a Data of }} \mathrm{N}_{2} \mathrm{O}$ soil emissions from Koks et al. [unpublished] measured in the same plantation

${ }^{b}$ Nutrient inputs from litter calculated as the product of litter nutrient concentrations (Chapter 3) and the average annual dry-weight of the fronds cut (from 2017 to 2019)

The inter-row, without external nutrient inputs, had comparable $\mathrm{N}$ than the palm circle, sustained by higher microbial biomass $\mathrm{N}$ and gross $\mathrm{N}$ mineralization (Chapter 2), but lower $\mathrm{Ca}$ and $\mathrm{K}$ contents (Fig. 4). Nutrient contents in the inter-row were comparable to the unfertilized rubber plantations and smallholder oil palm plantations with low fertilization rates in the same area (Allen et al. 2016).

The high organic matter in the frond-stacked area generated high porosity with 
consequently high infiltration and water drainage (Chapter 4), thus reducing runoff and favoring the groundwater recharge (Moradi et al. 2015, Tarigan et al. 2020). Also, given that the frond-stacked area hosts most faunal activity in this oil palm plantation (Potapov et al. 2020), infiltration rates are likely further enhanced by bioturbation (Colloff et al. 2010). The high drainage and high soil nutrient contents in this zone resulted in higher leaching of base cations but not of $\mathrm{N}$, for which leaching losses were higher in the inter-row (Fig. 4). Higher $\mathrm{N}$ retention efficiency in the frond-stacked area (0.98, Chapter 4) than in the inter-row (0.88) indicates higher retention in microbial biomass and higher root uptake by the palms. The latter was corroborated by findings of higher root density in the frond-stacked area than in the inter-row (Rüegg et al. 2019, Nelson et al. 2006). This is important as it indicates that the oil palm can use the nutrients from frond decomposition, and that root development is influenced by the spatial variability of soil fertility. The continuous application of fertilizer close to the palm's trunk prevented the roots to occupy the whole plantation area (Schroth et al. 2000), resulting in low nutrient uptake and high leaching fluxes in the inter-row (Fig. $4)$.

Possible options to mitigate high leaching in the inter-row are the application of lower fertilization rates and the development of ground vegetation (Chapter 4), as well as the increase of area covered by the frond stack, or the alternation of the inter-rows covered by the frond stack over the life span of the plantation. In fact, mulching with fronds improved several soil functions: it promoted soil fertility, soil nutrient cycle and retention, soil macrofauna activity, soil microbial biomass, as well as reduced runoff and provided groundwater recharge. 


\subsection{Comparison with smallholder oil palm plantations and forest}

The design of the EFForTS project offers the possibility to compare the studied largescale oil palm plantation with smallholder oil palm plantations and lowland tropical forest in the same area in Jambi province, the Harapan landscape (Drescher et al. 2016), on the same Acrisols with loam texture (Allen et al. 2015). The comparison with forest can illustrate the effects of land-use change from forest conversion to agricultural systems, whereas the comparison with smallholder oil palm plantations can show the effects of agricultural intensification. Compared to the large-scale plantations, the smallholder plantations in the study region had lower management intensity because of:

- lower fertilization rates, $88 \mathrm{~kg} \mathrm{~N}, 38 \mathrm{~kg} \mathrm{P}, 157 \mathrm{~kg} \mathrm{~K} \mathrm{ha}^{-1} \mathrm{yr}^{-1}$ (Kurniawan et al. 2018) versus $260 \mathrm{~kg} \mathrm{~N}, 50 \mathrm{~kg} \mathrm{P}, 220 \mathrm{~kg} \mathrm{~K} \mathrm{ha}^{-1} \mathrm{yr}^{-1}$;

- lower herbicide applications, on average $0.82 \mathrm{~L}_{\text {herbicide }} \mathrm{ha}^{-1} \mathrm{yr}^{-1}$ (Moulin et al. 2017) versus $2.25 \mathrm{~L} \mathrm{ha}^{-1} \mathrm{yr}^{-1}$. Also, herbicide was not applied regularly and not used by all farmers (Euler et al. 2016);

- lower liming, which was applied occasionally (Kurniawan et al. 2018), as seen by lower $\mathrm{pH}$ in the top-10- $\mathrm{cm}$ soil in the smallholders $(\mathrm{pH}=4.5)$ than in the largescale plantation (management-zones weighted average: $\mathrm{pH}=5.3$ );

- less regularity and lower frequency of harvest, which also resulted in lower frequency of pruning fronds, with an average of two harvest month ${ }^{-1}$ (Euler et al. 2016) compared to every 10 days in the large-scale plantation.

The partial $\mathrm{N}$ budget of these three land uses is compiled in Figure 5. The nutrient $\mathrm{N}$ was selected because it is important for oil palm growth and because $\mathrm{N}$ losses $\left(\mathrm{N}_{2} \mathrm{O}\right.$ emissions and $\mathrm{N}$ leaching) are connected to negative environmental impacts. 
Figure 5: Partial $\mathrm{N}$ budget (mean (standard error), $\mathrm{n}=4$ plots) in a large-scale oil palm plantation (conventional management treatment), smallholder oil palm plantations and forest on loam Acrisols in Jambi province, Indonesia. Fluxes are in $\mathrm{kg} \mathrm{ha}^{-1}$ $\mathrm{yr}^{-1}$ and pools in $\mathrm{kg}^{-1} \mathrm{ha}^{-1}$; microbial biomass $\mathrm{N}$ (MBN) measured in the top-5-cm depth and soil $\mathrm{N}$ for the top-50-cm depth.
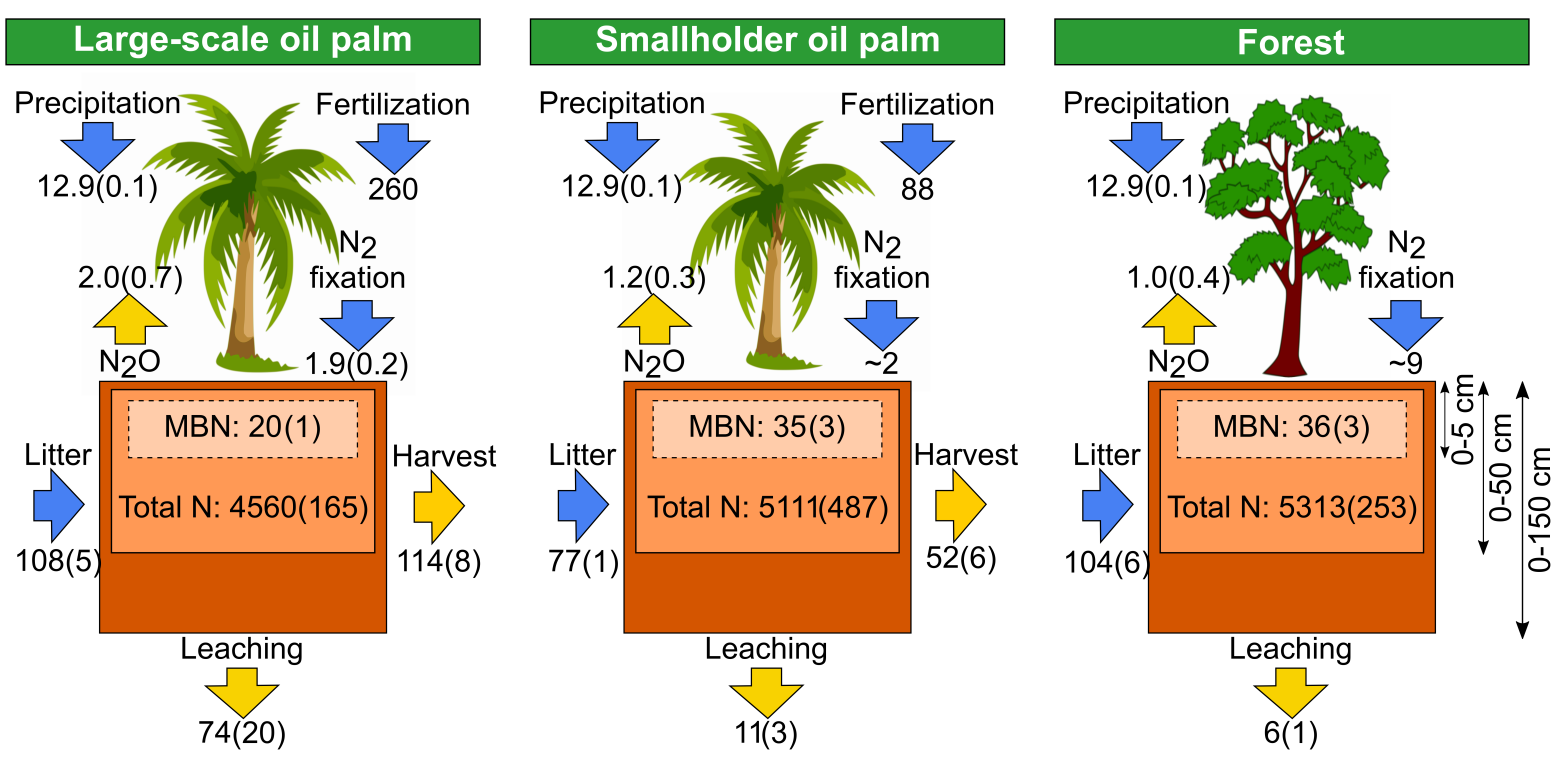

Sources:

- Data of precipitation in all land uses, and of fertilization and leaching in smallholder plantations and forest from Kurniawan et al. (2018).

- $\mathrm{N}_{2} \mathrm{O}$ soil emissions in the large-scale from Koks et al. [unpublished data], whereas $\mathrm{N}_{2} \mathrm{O}$ emissions in smallholder plantations and forest from Hassler et al. (2017).

- $\mathrm{N}_{2}$ fixation in smallholder assumed similar to large-scale plantations (Chapter 3), whereas $\mathrm{N}_{2}$ fixation in forest set as the global average of $\mathrm{N}_{2}$ fixation in evergreen broadleaf forests (Davies-Barnard and Friedlingstein 2020).

- $\mathrm{N}$ from litter in the large-scale plantation calculated as the product of $\mathrm{N}$ litter concentration (Chapter 3) and the average annual dry-weight of the fronds cut (from 2017 to 2019); N from litter in smallholder plantations and forest calculated as the product of $\mathrm{N}$ litter concentration (Kotowska et al. 2016) and litter production (Kotowska et al. 2015).

- $\mathrm{N}$ export via harvest calculated as the product of the $\mathrm{N}$ concentrations in fruit bunches in the large-scale (Chapter 2) and in smallholder plantations (Kotowska et al. 2016) and the yield in 2017 (monitored by Z01 group).

- Microbial biomass $\mathrm{N}$ and total $\mathrm{N}$ in smallholder plantations and forest from Allen et al. $(2015 ; 2016)$. 
The $\mathrm{N}$ fluxes and pools in the land uses were:

a. $\mathrm{N}_{2}$ fixation: due to the lack of data on $\mathrm{N}_{2}$ fixation in smallholder oil palm plantations and in forest it's not possible to make a precise comparison. However, higher $\mathrm{N}_{2}$ fixation is expected in the forest because, in addition to asymbiotic $\mathrm{N}_{2}$ fixation, $\mathrm{N}$ is fixed symbiotically by $\mathrm{N}$-fixing trees (e.g. Fabaceae, Rembold et al. 2017).

b. $\mathrm{N}_{2} \mathrm{O}$ soil emissions: rates of $\mathrm{N}_{2} \mathrm{O}$ emissions were the lowest in the forest and the highest in the large-scale plantation, so that they increased with higher of management intensity. This is likely due to increased $\mathrm{N}$ fertilization (Hassler et al. 2017). This process was a minor pathway for $\mathrm{N}$ losses in these systems but it has a profound effect on climate change, having a warming global potential of 265 (IPCC 2013), so that the reduction of $\mathrm{N}_{2} \mathrm{O}$ emissions is essential to reduce the environmental footprints of oil palm plantations.

c. $\mathrm{N}$ from litter: $\mathrm{N}$ fluxes from litter deposition were higher in large-scale compared to smallholder oil palm plantations. Since litter $\mathrm{N}$ concentrations were similar in the two oil palm plantations types $(1.3 \% \mathrm{~N}$ in large-scale Chapter $3 ; 1.4 \% \mathrm{~N}$ in smallholoder, Kotowska et al. 2016), this difference was due to lower frond litter production in smallholder plantations (5.5 $\pm 0.2 \mathrm{Mg} \mathrm{ha}^{-1} \mathrm{yr}^{-1}$, Kotowska et al. 2015) compared to the large-scale $\left(8.6 \pm 0.3 \mathrm{Mg} \mathrm{ha}^{-1} \mathrm{yr}^{-1}\right)$. The forest and the large-scale plantation had comparable fluxes of $\mathrm{N}$ from litter because of comparable litter production ( $8.3 \pm 0.5 \mathrm{Mg} \mathrm{ha}^{-1} \mathrm{yr}^{-1}$, Kotowska et al. 2015) and comparable litter $\mathrm{N}$ concentrations (1.2\% $\mathrm{N}$ in forest, Kotowska et al. 2016).

d. Soil N contents: microbial biomass N (MBN) was lower in the large-scale oil palm plantation than in the other land uses. This is probably a consequence of low return of organic matter to the soil, due to high harvest export and removal of ground vegetation with herbicide and by raking the palm circle (Chapter 2). Total $\mathrm{N}$ contents in soil were comparable among land uses. 
e. $\mathrm{N}$ harvest export: the harvest of fruit bunches was the main $\mathrm{N}$ loss pathway in both oil palm plantation systems. While the $\mathrm{N}$ concentrations in the fruit bunches were similar among these plantations $(0.8 \% \mathrm{~N}$ in large-scale, Chapter $3 ; 0.7 \% \mathrm{~N}$ in smallholder, Kotowska et al. 2016), the yield in smallholders plantations was 14 \pm 2 ha $^{-1}$ in 2017, which is much lower than the yield the large-scale plantation (27 $\pm 2 \mathrm{ha}^{-1}$ in 2017). Indeed smallholders in Indonesia commonly have lower yield than large-scale plantations because of different management practices (Lee et al. 2014).

f. $\mathrm{N}$ leaching losses: $\mathrm{N}$ leaching was the other main pathway of $\mathrm{N}$ loss from these systems. Similarly to $\mathrm{N}_{2} \mathrm{O}$ emissions, $\mathrm{N}$ leaching losses increased with higher management intensity, with the highest leaching in the large-scale plantation and the lowest in the forest, due to higher fertilizer inputs. In smallholder plantations the $\mathrm{N}$ leaching losses are just $12.5 \%$ of $\mathrm{N}$ fertilizer applied, and $\mathrm{N}$ retention efficiency is 0.99 (Kurniawan et al. 2018), compared to $27 \%$ of $N$ fertilizer leached and 0.88 of $\mathrm{N}$ retention efficiency in the large-scale plantation (Chapter 4). The efficient retention in smallholder plantations was likely the result of lower fertilization rates and lower herbicide application rates (Chapter 4). Also the larger microbial biomass in the smallholder plantations might have contributed to retain $\mathrm{N}$ more efficiently (Chapter 2).

To summarize, there was a gradient of increasing $\mathrm{N}$ losses from forest to smallholder oil palm plantations to large-scale plantations (Fig. 5), showing that forest conversion to agriculture and agricultural intensification generated higher $\mathrm{N}$ losses, and so larger environmental footprint. Because of low $\mathrm{N}$ inputs through $\mathrm{N}_{2}$ fixation and high $\mathrm{N}$ export through harvest (Fig. 5), the productivity in oil palm plantations has to be maintained by fertilization. The intensive management in the large-scale plantation sustained higher productivity than in smallholder plantations, as shown by higher yield and larger litter production, but also generated high N losses (Fig. 5). Research on 
yield gap in smallholder plantations in Jambi suggests that the yield can be enhanced by higher fertilization rates and by the application of the correct nutrient ratio, as well as by more frequent harvest (Euler et al. 2016, Woittiez et al. 2019). In large-scale oil palm plantations, our management experiment showed that fertilization rates equal to harvest export and mechanical weeding can reduce these $\mathrm{N}$ losses and maintain high levels of production. 


\section{References}

- Allen K, Corre MD, Kurniawan S, Utami SR, Veldkamp E (2016) Spatial variability surpasses land-use change effects on soil biochemical properties of converted lowland landscapes in Sumatra, Indonesia. Geoderma 284:42-50. doi:10.1016/j.geoderma.2016.08.010

- Allen K, Corre MD, Tjoa A, Veldkamp E (2015) Soil nitrogen-cycling responses to conversion of lowland forests to oil palm and rubber plantations in Sumatra, Indonesia. PloS One 10(7):e0133325. doi:10.1371/journal.pone.0133325

- Baba M, Abe S, Kasai M, Sugiura T, Kobayashi H (2011) Contribution of understory vegetation to minimizing nitrate leaching in a Japanese cedar plantation. Journal of Forest Research 16(6):446-455. doi:10.1007/s10310-010-0244-3

- Colloff MJ, Pullen KR, Cunningham SA (2010) Restoration of an ecosystem function to revegetation communities: the role of invertebrate macropores in enhancing soil water infiltration. Restoration Ecology 18:65-72. doi:10.1111/j.1526-100X.2010.00667.x - Corley RHV, Tinker PB (2016) The oil palm, 5th ed. John Wiley \& Sons, Ltd, Hoboken, NJ

- Darras KFA, Corre MD, Formaglio G, Tjoa A, Potapov A, Brambach F, Sibhatu KT, Grass I, Rubiano AA, Buchori D, Drescher J, Fardiansah R, Hölscher D, Irawan B, Kneib T, Krashevska V, Krause A, Kreft H, Li K, Maraun M, Polle A, Ryadin AR, Rembold K, Stiegler C, Scheu S, Tarigan S, Valdés-Uribe A, Yadi S, Tscharntke T, Veldkamp E (2019) Reducing fertilizer and avoiding herbicides in oil palm plantations - ecological and economic valuations. Frontiers in Forests and Global Change 2. doi:10.3389/ffgc.2019.00065

- Davies-Barnard T, Friedlingstein P (2020) The global distribution of biological nitrogen fixation in terrestrial natural ecosystems. Global Biogeochemical Cycles. doi:10.1029/2019GB006387

- Drescher J, Rembold K, Allen K, Beckschäfer P, Buchori D, Clough Y, Faust H, Fauzi AM, Gunawan D, Hertel D, Irawan B, Jaya INS, Klarner B, Kleinn C, Knohl A, Kotowska MM, Krashevska V, Krishna V, Leuschner C, Lorenz W, Meijide A, Melati D, Nomura M, Pérez-Cruzado C, Qaim M, Siregar IZ, Steinebach S, Tjoa A, Tscharntke T, Wick B, Wiegand K, Kreft H, Scheu S (2016) Ecological and socio-economic functions across tropical land use systems after rainforest conversion. Philosophical Transactions of the Royal Society of London. Series B, Biological sciences 371(1694). doi:10.1098/rstb.2015.0275 
- Dubos B, Snoeck D, Flori A (2017) Excessive use of fertilizer can increase leaching processes and modify soil reserves in two Ecuadorian oil palm plantations.

Experimental Agriculture 53(2):255-268. doi:10.1017/S0014479716000363

- Euler M, Hoffmann MP, Fathoni Z, Schwarze S (2016) Exploring yield gaps in smallholder oil palm production systems in eastern Sumatra, Indonesia. Agricultural Systems 146:111-119. doi:10.1016/j.agsy.2016.04.007

- Hassler E, Corre MD, Kurniawan S, Veldkamp E (2017) Soil nitrogen oxide fluxes from lowland forests converted to smallholder rubber and oil palm plantations in Sumatra, Indonesia. Biogeosciences 14:2781-2798. doi:10.5194/bg-14-2781-2017 - IPCC (2013) Climate change 2013: the physical science basis. Contribution of working group I to the fifth assessment report of the intergovernmental panel on climate change. Cambridge University Press

- Kotowska MM, Leuschner C, Triadiati T, Hertel D (2016) Conversion of tropical lowland forest reduces nutrient return through litterfall, and alters nutrient use efficiency and seasonality of net primary production. Oecologia 180:601-618. doi:10.1007/s00442-015-3481-5

- Kotowska MM, Leuschner C, Triadiati T, Meriem S, Hertel D (2015) Quantifying above- and belowground biomass carbon loss with forest conversion in tropical lowlands of Sumatra (Indonesia). Global Change Biology 21(10):3620-3634. doi:10.1111/gcb.12979

- Kurniawan S, Corre MD, Matson AL, Schulte-Bisping H, Utami SR, van Straaten O, Veldkamp E (2018) Conversion of tropical forests to smallholder rubber and oil palm plantations impacts nutrient leaching losses and nutrient retention efficiency in highly weathered soils. Biogeosciences 15:5131-5154. doi:10.5194/bg-15-5131-2018

- Lee JSH, Ghazoul J, Obidzinski K, Koh LP (2014) Oil palm smallholder yields and incomes constrained by harvesting practices and type of smallholder management in Indonesia. Agronomy for Sustainable Development 34(2):501-513.

doi:10.1007/s13593-013-0159-4

- Luke SH, Advento AD, Aryawan AAK, Adhy DN, Ashton-Butt A, Barclay H, Dewi JP, Drewer J, Dumbrell AJ, Edi, Eycott AE, Harianja MF, Hinsch JK, Hood ASC, Kurniawan C, Kurz DJ, Mann DJ, Matthews Nicholass KJ, Naim M, Pashkevich MD, Prescott GW, Ps S, Pujianto, Purnomo D, Purwoko RR, Putra S, Rambe TDS, Soeprapto, Spear DM, Suhardi, Tan DJX, Tao H-H, Tarigan RS, Wahyuningsih R, Waters HS, Widodo RH, Whendy, Woodham CR, Caliman J-P, Slade EM, Snaddon JL, Foster WA, Turner EC (2020)Managing oil palm plantations more sustainably: large-scale experiments within the Biodiversity and Ecosystem Function in Tropical 
Agriculture (BEFTA) programme. Frontiers in Forests and Global Change 2:e0133325. doi:10.3389/ffgc.2019.00075

- Ministry of Agriculture of Indonesia (2016) Oil palm replanting guideline. Regulation No: 18/Permentan/KB.330/5/2016

- Moradi A, Teh CBS, Goh KJ, Husni AMH, Ishak CF (2015) Effect of four soil and water conservation practices on soil physical processes in a non-terraced oil palm plantation. Soil and Tillage Research 145:62-71. doi:10.1016/j.still.2014.08.005

- Moulin M, Wohlfahrt J, Caliman J-P, Bessou C (2017) Deciphering agricultural practices and environmental impacts in palm oil plantations in Riau and Jambi provinces, Indonesia. International Journal of Sustainable Development \& World Ecology 24(6):512-523. doi:10.1080/13504509.2016.1239232

- Nelson PN, Banabas M, Scotter DR, Webb MJ (2006) Using soil water depletion to measure spatial distribution of root activity in oil palm (Elaeis Guineensis Jacq.) plantations. Plant and Soil 286:109-121. doi:10.1007/s11104-006-9030-6

- Pahan I (2010) Complete guide to oil palm, 8th edn. Penebar Swadaya, Jakarta, Indonesia

- Potapov A, Bonnier R, Sandmann D, Wang S, Widyastuti R, Scheu S, Krashevska V (2020) Aboveground soil supports high levels of biological activity in oil palm plantations. Frontiers in Ecology and the Environment. doi:10.1002/fee.2174 - Rembold K, Mangopo H, Tjitrosoedirdjo SS, Kreft H (2017) Plant diversity, forest dependency, and alien plant invasions in tropical agricultural landscapes. Biological Conservation 213:234-242. doi:10.1016/j.biocon.2017.07.020

- RSPO (2018) Principles and criteria. For the production of sustainable palm Oil

- Rüegg J, Quezada JC, Santonja M, Ghazoul J, Kuzyakov Y, Buttler A, Guillaume T (2019) Drivers of soil carbon stabilization in oil palm plantations. Land Degrad Dev 30(16):1-12. doi:10.1002/ldr.3380

- Schroth G, Rodrigues MRL, D'Angelo SA (2000) Spatial patterns of nitrogen mineralization, fertilizer distribution and roots explain nitrate leaching from mature Amazonian oil palm plantation. Soil Use and Management 16:222-229. doi:10.1111/j.1475-2743.2000.tb00197.x

- Sidhu M, CheongKeng K, Sinuraya Z, Kurniawan M, Hasyim A (2009) Resumption of manuring and its impact on the nutrient status, growth and yield of unfertilised oil palm. Planter 85(1004):675-689.

- Tao H-H, Snaddon JL, Slade EM, Caliman J-P, Widodo RH, Suhardi, Willis KJ (2017) Long-term crop residue application maintains oil palm yield and temporal stability of 
production. Agronomy for Sustainable Development 37(4):33.

doi:10.1007/s13593-017-0439-5.

- Tarigan S, Stiegler C, Wiegand K, Knohl A, Murtilaksono K (2020) Relative contribution of evapotranspiration and soil compaction to the fluctuation of catchment discharge: case study from a plantation landscape. Hydrological Sciences Journal 58(6):1-10. doi:10.1080/02626667.2020.1739287

- Teuscher M, Gérard A, Brose U, Buchori D, Clough Y, Ehbrecht M, Hölscher D, Irawan B, Sundawati L, Wollni M, Kreft H (2016) Experimental bodiversity erichment in oil-palm-dominated landscape in Indonesia. Frontiers in Plant Science 7:1538. doi:10.3389/fpls.2016.01538

- Tiemann TT, Donough CR, Lim YL, Härdter R, Norton R, Tao HH, Jaramillo R, Satyanarayana T, Zingore S, Oberthür T (2018) Feeding the palm: a review of oil palm nutrition. Advances in Agronomy 152:149-243. doi:10.1016/bs.agron.2018.07.001 - Woittiez LS, Turhina SRI, Decci D, Slingerland M, van Noordwijk M, Giller KEEN (2019) Fertiliser application practices and nutrient deficiencies in smallholder oil palm plantations in Indonesia. Experimental Agriculture 55(4):543-559.

doi:10.1017/S0014479718000182 


\section{Acknowledgements}

I acknowledge the the DFG for the funding of my research within the CRC990-EFForTS project.

I thank my supervisors, Marife D. Corre and Edzo Veldkamp, for offering me this stimulating $\mathrm{PhD}$ project and for the guidance provided along the way through discussions and challenges.

I gratefully acknowledge all the people involved with the management of the EFForTS project, for making it possible to work in Jambi. Thank you for your guidance, help, and organization. I especially thank our counterpart Aiyen Tjoa for the tireless assistance and valuable knowledge.

I am especially grateful for my Indonesian field assistants Happy, Fajar, Sofyan, Nikita, Nando, and Somad for the countless hours spent in the plantation, for the motorbike rides overloaded with material, for all the time spent together in the laboratory.

I thank my colleagues of the PTS group, Marcus, Rodine, Najeeb, Oliver, Leonie, Guntars, Rafael, Cecille, Jie, Xenia, Guodong, Guantao, and Dan for the coffee breaks and the lunches together. Also, I thank the lab staff, Andrea, Kerstin, Martina, and Natalia for dealing with my huge amount of samples.

A special thank goes to Joost, the best colleague I could have asked for. I was so lucky to have you next to me to share all the laughs and all the tears during this PhD.

I thank my "Jambi Crew", Florian, Joyson, Clara, Isabelle, Rico, Rhami, Carina, Britta, Dirk, Tatiana, Kristina, and Johannes for all the moments shared in Indonesia and in Göttingen. Thank you for the skylounge evenings, the birthday parties, the karaoke nights, the trips, the gossip moments. And thank to a special member of this crew, Pierre-Andre, for being my life companion.

Finally, I thank my family for always supporting me and for being in my life despite the distance. 